\title{
JOURNAL OF
POLITICAL ISSUES JOURNAL OF POLITICAL ISSUES
}

\begin{tabular}{|c|c|c|c|c|}
\hline VOLUME & NOMOR & TAHUN & HALAMAN & ISSN \\
\hline 2 & 2 & Januari & $67-1342785-7766$ \\
\hline
\end{tabular}

Dinamika Pelaksanaan Kebijakan Program Pelayanan Penyandang Masalah Kesejahteraan Sosial Anak Jalanan

pp. 67-78

(Vita Rachmawati \& Dodi Faedlulloh)

Peran World Health Organization dalam Menangani Isu Female Genital Mutilation di Sierra Leone

pp. $79-88$

(Ardli Johan Kusuma \& Isabella Putri Maharani)

Perbandingan Tata Kelola Penanganan Pandemi Covid-19 di Indonesia dan India

pp. 89-101

(Nisa Khoerunisa \& Faisal Fadilla Noorikhsan)

Formulasi Peraturan Desa tentang Lubuk Laragan

pp. 102-114

(Bustanuddin \& Dasril Radjab)

Tindakan Pencegahan Pembakaran Hutan dalam Perspektif ASEAN Community

pp. 115-123

(Retno Kusniati, Bunga Permatasari, \& Mohamad Rapik)

Politik Hukum Kewenangan Pemerintah Daerah dalam Pengaturan Hak Kekayaan Intelektual

pp. 124-134

(Darwance, Yokotani, \& Wenni Anggita) 


\section{CALL FOR PAPER:}

Journal of Political Issues (JPI) menerima naskah hasil penelitian, kajian mauun pemikiran kritis mengenai isu-isu daam lingkup bidang politik yang orisinil dan belum pernah dimuat/dipublikasi di jurnal maupun majalah lain. Naskah diketik dengan menggunakan Ms Word menggunakan Bahasa Indonesia dengan ketentuan spasi tnggal huruf Times New Romans, ukuran kertas A-4, dan banyak kata berjumlah 3.000-6.000 kata atau 8-15 halaman. Naskah di submit online melalui laman https://jpi.ubb.ac.id/index.php/JPI, serta dilengkapi dengan keaslian Naskah dan daftar riwayat hidup penulis. Redaksi JPI berhak melakukan penilaian dan penyuntingan terhadap naskah yang masuk. Naskah yang lolos seleksi oleh redaksi, akan di review oleh Mitra Bestari (Reviewer). Petunjuk penulisan selengkapnya dapat dilihat di https://jpi.ubb.ac.id/index.php/JPI

Sub tema naskah meliputi:

- Demokrasi

- Desentralisasi

- Partai Politik

- Kebijakan Publik

- Pemilu

- Kemanan dan Politik Internasional

- Gerakan Sosial

- Gender dan Politik Identitas

- Kesejahteraan Sosial

- Masyarakat dan Manajemen Publik

\section{JOURNAL OF POLITICAL ISSUES SUDAH TERINDEKS DI:}
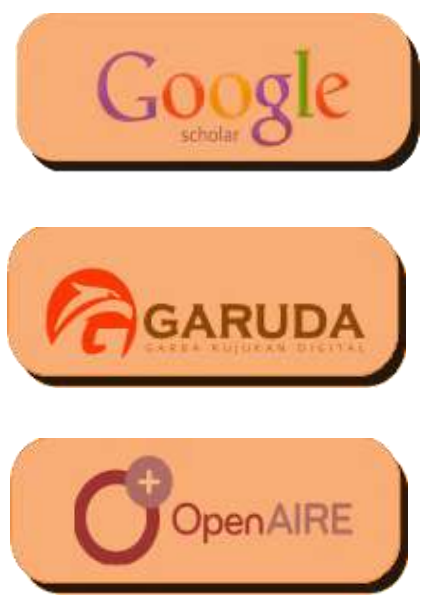
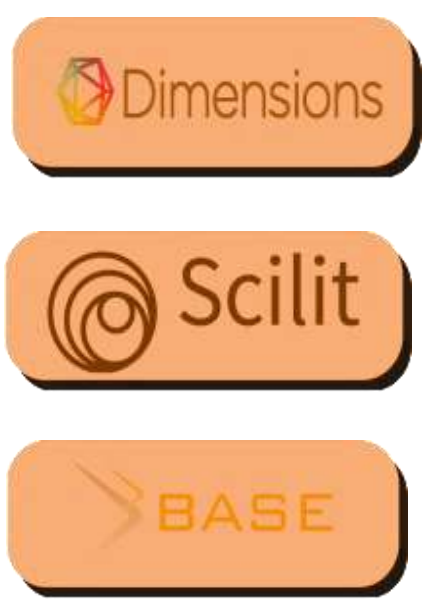
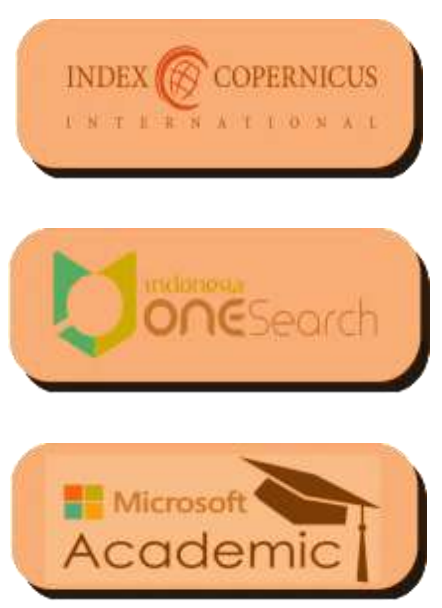
e-ISSN: 2685-7766

\title{
Volume 2 Nomor 2, Januari 2021
}

Journal of Political Issues diterbitkan pertama kali pada bulan Juli 2019 dan saat ini secara konsisten diterbitkan sebanyak 2 kali dalam setahun setiap Juli dan Desember oleh Jurusan Ilmu Politik Universitas Bangka Belitung.

Pengarah:

Kepala Jurusan Ilmu Politik, Universitas Bangka Belitung

\section{Pemimpin Redaksi/Penanggung Jawab (Editor in Chief): Ranto, M.A.}

Redaktur (Managing Editor): Komang Jaka Ferdian, M.Si.

Penyunting (Section Editor):

Bahjatul Murtasidin, M.Si. Sandy Pratama, M.Si. Rendy, M.A.

La Ode Muhamad Muliawan, M.A. Amir Syamsuadi, M.Si.

Restu Karlina Rahayu, S.IP., M.Si

\section{Dewan Editor (Editorial Board)}

Dr. H. S. Tisnanta, M.H.

Dr. Yusa Djuyandi, M.Si.

Dr. Oki Hajiansyah Wahab, M.H.

\section{Copy Editor \& Lay Out Edtior: \\ Agun Sutrisno, A.md.}

\section{Mitra Bestari (Reviewer):}

Prof. Syarif Hidayat (Ilmu Politik, Universitas Nasional, Jakarta)

Leo Agustino, M.Si., Ph.D. (Administrasi Publik, Universitas Sultan Ageng Tirtayasa, Banten) Luthfi Makhasin, M.Si., Ph.D. (Ilmu Politik, Universitas Jenderal Soedirman, Purwokerto) Agung Wibowo, M.Si. Ph.D. (Jurusan Kehutanan, Universitas Palangkaraya, Palangkaraya) Dr. Ibrahim, M.Si. (Ilmu Politik, Universitas Bangka Belitung, Kepulauan Bangka Belitung)

Dr. Ratnia Solihah, M.Si. (Ilmu Politik, Universitas Padjadjaran, Bandung) Dr. Sulistya Ekwati, M.Si. (Puslitbang Sosial Ekonomi KLHK, Jakarta)

Dr. Yusnarida Eka Nizmi, M.Si. (Hubungan Internasional, Unviersitas Riau, Riau)

Dr. Pahrudin HM, M.A. (Ilmu Pemerintahan, STISIP Nurdin Hamzah, Jambi)

Dr. Ardli Johan Kusuma, M.H.I. (Hubungan Internasional, Universitas 17 Agustus 1945 Jakarta)

Dodi Faedlulloh, M.Si. (Administrasi Publik, Universitas Lampung, Lampung)

Restu Rahmawati, M.A. (Ilmu Politik, Universitas 17 Agustus 1945 Jakarta)

\author{
Alamat: \\ Jurusan Ilmu Politik, Fakultas Ilmu Sosial dan Ilmu Politik Universitas Bangka Belitung \\ Jl. Kampus Terpadu UBB, Desa Balunijuk, Kecamatan Merawang, Kabupaten Bangka Provinsi Kepulauan \\ Bangka Belitung, Kode Pos: 33172, Indonesia \\ Email: editor@jpi.ubb.ac.id \\ Url: https://jpi.ubb.ac.id/index.php/JPI \\ e-ISSN: 2685-7766
}


Peran World Health Organization dalam Menangani Isu Female Genital Mutilation di Sierra Leone

(Ardli Johan Kusuma1\& Isabella Putri Maharani)

Pendekatan Advokasi Muhammadiyah dalam Penanganan Terorisme di Indonesia (Firmansyah \& Arief Hidayat)

Dinamika Pengaruh Ormas dalam Pengisian Anggota KPU

(Masum Busthomi \& M. Iwan Satriawan)

Potret Dinasti Politik dalam Pengisian Jabatan Administratif

(Ramlan Darmansyah, Siti Desma Syahrani \& Zulfa Harirah MS)

Menggali Intervensi Solutif dan Alternatif Kebijakan terhadap Problem Demografi Lokal

(Amir Dedoe)

Relasi antara Politik Identitas terhadap Proteksi Perdagangan di bawah Pemerintahan Donald Trump

(M. Chairil Akbar, Garcia Krisnando Nathanael Ginting \& Anwar Ilmar) 


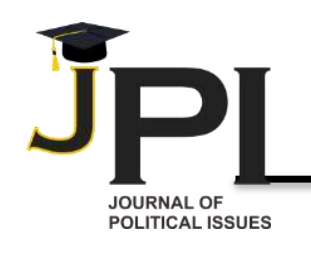

\section{Jurusan IImu Politik, FISIP, Universitas Bangka Belitung Salam Redaksi}

Salam Hangat. . .

Tiada kata yang dapat mewakili kegembiraan kami saat menyampaikan edisi pertama Journal of Political Issues. Journal of Political Issues kini hadir kemballi dengan terbitan terbaru Volume 2 Nomor 2 Januari 2021 yang terbit sesuai dengan jadwal yang ditargetkan. Melalui proses Open Journal System, secara tidak langsung dapat kita sadari bahwa peran dari teknologi dapat membantu kita dalam berbagai macam hal, terutama dalam mengelola jurnal secara elektronik.

Terbitan Januari, Volume 2 Nomor 2 kali ini memuat enam artikel berbobot dan menarik yang dikontribusikan oleh para penulis dari berbagai instansi baik di Indonesia. Berbagai macam tema dalam bidang politik dalam edisi ini akan membawa pembaca untuk lebih dekat dengan dunia sains dalam bidang Politik. Artikel pertama ditulis oleh Vita Rachmawati dan Dodi Faedlulloh menggambarkan proses komunikasi dalam pelaksanaan penanganan anak jalanan di DKI Jakarta belum terlaksana dengan baik. Artikel kedua ditulis oleh Ardli Johan Kusuma dan Isabella Putri Maharani menggambarkan terkait implementasi CEDAW oleh pemerintah Sierra Leone dalam masalah penghapusan Female Genital Mutilation tidak diterapkan secara baik oleh pemerintah Sierra Leone dikarenakan pemerintah tidak memasukan undang-undang kedalam hukum nasionalnya mengenai penghapusan praktik tradisional berbahaya yaitu FGM.

Artikel ketiga ditulis oleh Nisa Khoerunisa dan Faisal Fadilla Noorikhsan menjelaskan bahwa evaluasi menyeluruh terhadap kebijakan pemerintah Indonesia dalam penanganan covid 19. Pasalnya, kini Indonesia menduduki posisi teratas statistik jumlah kematian akibat COVID-19 di Asia Tenggara. Artikel keempat ditulis oleh Bustanuddin dan Dasril Radjab yang menjelaskan bahwa dalam suatu kajian akan kebutuhan produk hukum desa bagi masyarakat Desa Sungai Rotan sebagai pedoman dalam bermasyarakat khususnya berkenaan dengan tanggaung jawab akan kelestarian lingkungan hidup. Artikel kelima ditulis oleh Retno Kusniati, Bunga Permatasari, dan Mohamad Rapik yang menjelaskan bahwa nilai-nilai ASEAN Community telah tertuang dalam setiap pasal yang diatur dalam AATHP guna pencegahan kebakaran hutan dan lahan yang terjadi pada kawasan ASEAN. Artikel ke enam ditulis oleh Darwance, Yokotani, dan Wenni Anggita yang menjelaskan bahwa dari seluruh peraturan perundang-undangan bidang HKI, kewenangan pemerintah daerah secara eksplisit hanya diatur dalam Undang-Undang Merek dan Indikasi Geografis. Selebihnya penyebutannya bersifat umum, misalnya penggunaan istilah "negara" dalam Undang-Undang Hak Cipta sebagai pemegang ekspresi budaya tradisional dan hak cipta atas ciptaan yang penciptanya tidak diketahui.

Akhirnya, Journal of Political Issues mengucapkan terima kasih dan penghargaan setinggi-tingginya kepada tim pengelola edisi Journal of Political Issues Volume 2 Nomor 2 Januari 2021 serta kepada mitra bestari (Reviewer) yang berperan aktif membantu penerbitan jurnal ini. Journal of Political Issues tidak akan pernah berhenti untuk mengedepankan kualitas artikel yang diterbitkan dan terus berusaha secara konsisten untuk mempersiapkan dan mempersembahkan pengetahuan baru dalam lingkup Politik. Kami berharap artikelartikel tersebut akan memberikan manfaat bagi para pembaca dalam menambah wawasan. Kami juga mengajak para pembaca berkontribusi untuk berbagi ilmu dan bidang keahliannya untuk menuliskan karya ilmiah dalam bentuk jurnal di edisi Journal of Political Issues Volume 2 Nomor 2 Januari 2021 yang akan terbit sesuai dengan target terbitan. Terima Kasih.

Selamat membaca, Salam Publikasi! 


\section{Dinamika Pelaksanaan Kebijakan Program Pelayanan Penyandang Masalah Kesejahteraan Sosial Anak Jalanan}

\begin{abstract}
Vita Rachmawati ${ }^{1}$, Dodi Faedlulloh ${ }^{2 *}$
${ }^{1}$ Program Studi Ilmu Administrasi Publik, Universitas 17 Agustus 1945 Jakarta, 14350, Jakarta Utara-Indonesia

${ }^{2}$ Jurusan Ilmu Administrasi Negara, Universitas Lampung, 35141, Bandar Lampung-Indonesia

\begin{tabular}{l}
\hline \hline Info Artikel \\
\hline Dikirim: Okt 26, 2020 \\
Diterima: Jan 18, 2021 \\
Dipublikasi: Jan 31, 2021 \\
\hline Kata Kunci: \\
Anak Jalanan; \\
Kebijakan; \\
Kesejahteraan; \\
\hline
\end{tabular}

Koresponden:

Dodi Faedlulloh

Jurusan Ilmu Administrasi

Negara

Universitas Lampung

\section{Email:}

dodi.faedlulloh@fisip.unil

ABSTRAK

Abstract This research is motivated by the relatively high number of people with social welfare problems for street children in North Jakarta compared to other cities in the DKI Jakarta Province. Therefore, serious efforts from the government are needed to overcome this problem. This study discusses the dynamics of the implementation of the policy on the service program for people with social welfare problems for street children in North Jakarta.. This study uses a qualitative method. To select informants, researchers used purposive sampling. To measure the validity of the study, the researcher used source triangulation by comparing data from observations and interviews, conditions with people's perspectives, and interviews with document content. The results showed that the communication process in the implementation of handling street children has not been implemented properly. This occurs because there are conditions in the delivery of information that are still ineffective. Furthermore, resources related to staff, information, authority, and facilities also each have shortcomings so that they lack effectiveness in terms of policy resources. In the context of disposition, it shows that policy implementers have not yet optimal responses in implementing policies on handling street children in North Jakarta. Meanwhile, from the bureaucratic structure, the implementing institution has its own SOP. The implementation of policies on handling street children in North Jakarta has not experienced fragmentation.
\end{abstract} a.ac.id

\section{Sitasi Cantuman:}

Rachmawati, V., \& Faedlulloh, D. (2021). Dinamika Pelaksanaan Kebijakan Program Pelayanan Penyandang Masalah Kesejahteraan Sosial Anak Jalanan. Journal of Political Issues. 2(2); $\quad$ 67-78. https://doi.org/10.33019/jpi.v $2 \mathrm{i} 2.38$

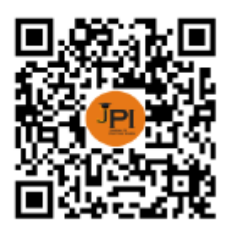

DOI:

https://doi.org/10.33019/jpi.v $2 \mathrm{i} 2.38$

Lisensi:

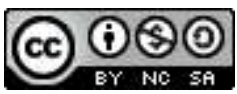

Attribution-NonCommercialShareAlike 4.0 International (CC- BY-NC-SA 4.0)

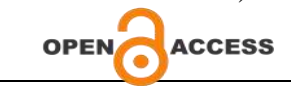

Abstrak Penelitian ini dilatarbelakangi oleh cukup tingginya jumlah penyandang masalah kesejahteraan sosial anak jalanan di Jakarta Utara dibandingkan dengan Kota lain di wilayah Provinsi DKI Jakarta. Oleh karenanya perlu upaya serius dari pemerintah untuk mengatasi permasalahan ini. Penelitian ini membahas tentang dinamika pelaksanaan kebijakan program pelayanan penyandang masalah kesejahteraan sosial anak jalanan di Jakarta Utara. Penelitian ini menggunakan metode kualitatif. Untuk memilih informan peneliti menggunakan purposive sampling. Untuk mengukur validitas penelitian, peneliti menggunakan triangulasi sumber dengan membandingkan data hasil pengamatan dan wawancara, keadaan dengan perspektif orang, dan hasil wawancara dengan isi dokumen. Hasil penelitian menunjukkan proses komunikasi dalam pelaksanaan penanganan anak jalanan belum terlaksana dengan baik. Hal ini terjadi karena ada kondisi penyampaian informasi yang masih kurang efektif. Selanjutnya sumberdaya yang berkaitan dengan staff, information, authority, dan facilities juga masing-masing memiliki kekurangan sehingga kekurangan efektivitas dalam hal sumberdaya kebijakan. Dalam konteks disposisi menunjukkan bahwa para pelaksana kebijakan memiliki respon yang belum optimal dalam menjalankan kebijakan penanganan anak jalanan di Jakarta Utara. Sedangkan dari stuktur birokrasi, institusi pelaksana telah memiliki SOP tersendiri. Pelaksanaan kebijakan penanganan anak jalanan di Jakarta Utara tidak mengalami fragmentasi.

Tentang:

Vita Rachmawati, Penulis menyelesaikan studi S1 di Program Studi IlmuAdministrasi Publik, Universitas 17 Agustus 1945 Jakarta.

Dodi Faedlulloh, Penulis menyelesaikan studi S2 di Magister Ilmu Administrasi Universitas Jenderal Soedirman tahun 2014. Saat ini penulis bekerja sebagai dosen di Jurusan Ilmu Administrasi Negara, Universitas Lampung. 


\section{PENDAHULUAN}

Salah satu permasalahan urban yang sering ditemui adalah masalah kesejahteraan sosial anak jalanan. Seringkali fenomena anak jalanan di sudut-sudut kota menjadi pemandangan seharihari yang lazim ditemui masyarakat. Tidak ada waktu belajar, masa kecil mereka terserap oleh kerja-kerja jalanan untuk sekadar bertahan hidup. Terminologi yang digunakan negara untuk "mendefiniskan" permasalahan ini sebagai Penyandang Masalah Kesejahteraan Sosial (PMKS). Walaupun terkini, ada wacana dari Kementerian Sosial yang akan mengganti sebutan bagi penerima bantuan sosial dari PMKS menjadi Pemerlu Pelayanan Kesejahteraan Sosial (PPKS). Namun secara paradigmatik, kita perlu memberikan kontribusi kritik apakah titik koordinat pandangan negara dalam melihat permasalahan ini bergeser pula atau tidak. Hal ini layak untuk didiskusikan lebih mendalam.

Penyandang Masalah Kesejahteraan Sosial (PMKS) merupakan seseorang, keluarga atau kelompok masyarakat yang karena suatu hambatan, kesulitan atau gangguan tidak dapat melaksanakan fungsi sosialnya, sehingga tidak dapat terpenuhi kebutuhan hidupnya baik jasmani, rohani dan sosial secara memadai dan wajar (Suleman et al., 2019). Hambatan, kesulitan dan gangguan tersebut dapat berupa kemiskinan, keterlantaran, kecacatan, ketunaan sosial, keterbelakangan, keterasingan atau keterpencilan dan perubahan lingkungan (secara mendadak) yang kurang mendukung, seperti terjadinya bencana. Dari dua puluh enam jenis penyandang masalah kesejateraan sosial, meliputi Anak Balita Telantar, Anak Telantar, Anak Nakal, Wanita Rawan Sosial Ekonomi, Korban Tindak Kekerasan, Lanjut Usia Telantar, Penyandang Cacat, Tuna Susila, Pengemis, Gelandangan, Korban Penyalahgunaan NAPZA, Keluarga Fakir Miskin dll, salah satunya ialah anak jalanan yang telah disinggung di awal.

Keberadaan anak jalanan dilatarbelakangi oleh kemiskinan, penyimpangan kepribadian, dan faktor luar dari anak jalanan tersebut. Faktanya sebagian besar anak jalanan memang berasal dari keluarga miskin. Hal inilah yang merupakan pemicu utama anak melakukan kegiatan di jalanan. Kondisi tersebut terjadi akibat tidak terpenuhi kebutuhan hidupnya (Astri, 2014). Secara Psikologis, anak jalanan adalah anak -anak yang pada suatu taraf tertentu belum memiliki cukup mental dan emosional yang kuat, Sementara mereka harus bergelut dengan dunia jalanan yang keras dan cenderung berpengaruh negatif bagi perkembangan dan pembentukan kepribadiannya (Suyanto, 2013).

Pada umumnya problem anak jalanan banyak berada di kota-kota, keberadaan mereka pun juga tersebar hampir di seluruh dunia terutama negara berkembang seperti di Indonesia (Mambang \& Wahyudi, 2016). Fenomena anak jalanan berhubungan dengan masalah-masalah lain, baik secara internal maupun eksternal, seperti ekonomi, psikologi, sosial, budaya, lingkungan, pendidikan, agama, dan keluarga. Mereka korban dari kondisi yang dialami individu, baik internal, eksternal maupun kombinasi keduanya. Munculnya anak jalanan, tidak bisa dilihat dari faktor ekonomi saja, tetapi banyak faktor yang menjadi pemicu, seperti kemiskinan, perhatian keluarga, kenakalan remaja, pola asuh yang salah (Khoirunnisa et al., 2020).

Masalah sosial anak jalanan merupakan fenomena sosial yang tidak bisa dihindari keberadaannya dalam kehidupan masyarakat, terutama yang berada di daerah perkotaan. Salah satu faktor yang dominan mempengaruhi perkembangan masalah ini adalah kemiskinan. Masalah kemiskinan di Indonesia berdampak negatif terhadap meningkatnya arus urbanisasi dari daerah pedesaan ke kota-kota besar. Sehingga lapangan pekerjaan yang tersedia, serta terbatasnya pengetahuan dan keterampilan menyebabkan mereka banyak yang mencari nafkah untuk mempertahankan hidup dengan terpaksa menjadi anak jalanan. 
Tabel 1 Data Anak Jalanan di Suku Dinas Sosial di Wilayah Jakarta Tahun 2015 s/d Tahun 2016

\begin{tabular}{ccccc}
\hline \multirow{2}{*}{ No } & Anak Jalanan di Wilayah & $\mathbf{2 0 1 5}$ & 2016 & Jumlah \\
\cline { 3 - 5 } 1. & Jakarta Utara & 551 Jiwa & 405 Jiwa & 956 Jiwa \\
\hline 2. & Jakarta Selatan & 75 Jiwa & 215 Jiwa & 290 Jiwa \\
\hline 3 & Jakarta Pusat & 108 Jiwa & 150 Jiwa & 213 Jiwa \\
\hline 4. & Jakarta Barat & 263 Jiwa & 275 Jiwa & 538 Jiwa \\
\hline 5 & Jakarta Timur & 260 Jiwa & 285 Jiwa & 545 Jiwa \\
\hline & Total & 1257 Jiwa & 1330 Jiwa & 2542 Jiwa \\
\hline & \multicolumn{2}{c}{ Sumber: Suku Dinas Sosial Jakarta Utara Tahun }
\end{tabular}

Berdasarkan tabel di atas, jumlah penyandang masalah kesejahteraan sosial anak jalanan di Suku Dinas Sosial paling banyak di Wilayah Jakarta Utara dengan jumlah 956 jiwa. Dalam hal ini, untuk meminimalisir jumlah penyandang masalah kesejahteraan sosial anak jalanan, Pemerintah telah kebijakan penanganan anak jalanan melalui penjangkauan dan pemulangan penyandang masalah kesejahteraan sosial ke daerah asal yang diatur dalam Peraturan Daerah No. 8 Tahun 2007 tentang ketertiban umum bebas penyandang masalah kesejahteraan sosial jalanan.

Anak jalanan merupakan anak berusia 5-18 tahun baik laki-laki maupun perempuan yang menghabiskan sebagian besar waktunya di jalan, memiliki komunikasi yang minimal atau sama sekali tidak pernah berkomunikasi dengan keluarga dan kurang pengawasan, perlindungan dan bimbingan sehingga rawan terkena gangguan kesehatan dan psikologi (UNICEF) (Azmiyati, 2014). Peran pemerintah dalam menangani masalah sosial anak jalanan sangat penting, sebagaimana yang diamanatkan dalam Pasal 27 Ayat (2) dan Pasal 34 Ayat (1) Undang-Undang Dasar Negara Republik Indonesia Tahun 1945 Amandemen keempat. Pasal 27 Ayat (2) Undang-Undang Dasar 1945 Amandemen keempat berbunyi "Tiap-tiap warga negara berhak atas pekerjaan dan penghidupan yang layak bagi kemanusiaan". Pasal ini memberikan pengertian bahwa pemerintah berkewajiban untuk memberantas pengangguran dan harus mengusahakan supaya setiap warga negara dapat memperoleh pekerjaandengan upah yang layak untuk hidup. Salah satunya dimanifestasikan dengan cara merumuskan kebijakan program pelayanan Penyandang Masalah Kesejahteraan Sosial (PMKS) untuk menanggulangi masalah anak jalanan tersebut. Karena semua masalah yang timbul merupakan agenda tetap pemerintah untuk mendapatkan penyelesaiannya dengan menuangkannya melalui kebijakan-kebijakan yang dibuat oleh pemerintah.

Kebijakan Pemerintah Daerah Kota Jakarta Utara untuk menangani anak jalanan sendiri juga dibuat berdasarkan pada peraturan perundang-undangaan yang telah ada sebelumnya yaitu Peraturan perundang-undangan yang berkaitan dengan kesejahteraan anak jalanan antara lain: UU No. 11 Tahun 2009 tentang Kesejahteraan Sosial, Peraturan Pemerintah No. 31 Tahun 1980 tentang Penanggulangan anak jalanan anak terlantar, Peraturan Daerah No. 8 tahun 2007 tentang ketertiban umum bebas penyandang masalah kesejahteraan sosial Jalanan, Kepmensos No. 30/HUK/1996 tentang rehabilitasi anak jalanan di dalam panti sosial, Peraturan Gubernur No. 19 tahun 2014 tentang satuan pelayanan pengawasan dan pengendalian sosial penyandang masalah kesejahteraan sosial jalanan.

Beberapa peraturan perundangan tersebut di atas merupakan kebijakan publik atau yang sering disebut kebijakan negara, karena kebijakan itu dibuat negara. Bila dikaitkan dengan tujuan kebijakan, maka yang hendak dicapai adalah untuk mewujudkan kehidupan yang sejahtera untuk kaum marjinal di Indonesia. Dalam bentuknya yang positif, kebijakan publik didasarkan pada undang-undang dan bersifat otoritatif. Sifat kebijakan bisa diperinci menjadi beberapa kategori yakni tuntutan-tuntutan kebijakan (policy demands), keputusankeputusan kebijakan (policy decision), pernyataan-pernyataan kebijakan (policy statements), 
hasil-hasil kebijakan (policy outputs), dan dampak-dampak kebijakan (policy outcomes)(Winarno, 2008).

Kebijakan tidak berada dalam ruang vakum, oleh karenanya kebijakan selalu berkelindan dengan kondisi riil masyarakat. Kebijakan tidak hanya dirumuskan lalu dibuat dalam suatu bentuk positif seperti undang-undang dan kemudian didiamkan, tetapi sebuah kebijakan publik harus dilaksanakan atau di implementasikan melalui program-program agar mempunyai dampak kepada masyarakat. Tetapi pada kenyataanya tidak semua program pelayanan pada Suku Dinas Sosial berjalan sesuai dengan apa yang diharapkan dan direncanakan. Dalam pelaksanaan otonomi daerah yang mana pemerintah daerah diberikan wewenang untuk mengurus rumah tangganya sendiri. Maka dengan adanya indikasi tersebut Pemerintah Daerah Kota Jakarta Utara melalui Suku Dinas Sosial yang menagani masalah sosial, khususnya anak jalanan akan sangat berperan sekali dalam mengatasi masalah anak jalanan yang semakin lama semakin rumit.

Dalam menjalankan program pelayanan penyandang masalah kesejahteraan sosial anak, Suku Dinas Sosial Jakarta Utara bekerja sama dengan beberapa Panti Sosial yaitu Panti Sosial Bina Bangun Daya 2 Cipayung Jakarta Timur dan Panti Sosial Bina Bangun Daya 1 Kedoya Jakarta Barat yang khusus menagani masalah anak jalanan. Bagi PMKS anak jalanan yang berada di panti tersebut akan diberikan bekal pemberdayaan masyarakat seperti pelatihan dan pembinaan serta diajarkan berbagai keterampilan dan kerajinan tangan sesuai dengan minat dan bakatnya masing-masing, sehingga pada saat PMKS anak jalanan ini keluar dari panti mereka mempunyai kemampuan dan keahlian dalam menghasilkan sebuah karya seni berupa kerajinan tangan yang memiliki nilai jual ekonomis yang tinggi untuk meningkatkan pekonomian mereka. Diharapkan nantinya dengan program program pelayanan yang diberikan oleh Suku Dinas Sosial Jakarta Utara tersebut dapat memberikan salah solusi alternatif untuk mengurangi jumlah anak jalanan dan mengembalikan mereka untuk hidup normal dan layak di dalam masyarakat.

Dari latar belakang di atas, penulis tertarik untuk meneliti tentang dinamikan pelaksanaan program pelayanan penyandang masalah kesejahteraan sosial anak di DKI Jakarta. Adapun tujuan diadakan penelitian ini adalah untuk mengetahui dinamika proses pelaksanaan Kebijakan Program Pelayanan Penyandang Masalah Kesejahteraan Sosial (PMKS) Anak Jalanan pada Suku Dinas Sosial di Jakarta Utara.

\section{METODE PENELITIAN}

Secara sistematis, penelitian ini menggunakan metode kualitatif. Metode kualitatif merupakan prosedur pengumpulan data yang menghasilkan data deskriptif berupa kata-kata tertulis atau lisan dari orang-orang dan perilaku yang diamati (Moleong, 2004). Sedangkan untuk memilih informan peneliti menggunakan purposive sampling yaitu Kepala Seksi Rehabilitasi dan pemberdayaan sosial, Staf Rehabilitasi Sosial, Petugas Pengawasan dan Pengendalian Sosial (P3S), masyarakat, dan anak jalanan.

Lokasi penelitian ini dilakukan di Kantor Suku Dinas Sosial Jakarta Utara. Adapun Suku Dinas Sosial Jakarta Utara memiliki beberapa anak asuhan. Semua anak jalanan tersebut dititipkan di Panti Sosial Bina Bangun Daya 2 Cipayung Jakarta Timur dan Panti Sosial Bina Bangun Daya 1 Kedoya Jakarta Barat. Untuk mengukur validitas penelitian, peneliti menggunakan triangulasi sumber dengan membandingkan data hasil pengamatan dan wawancara, keadaan dengan perspektif orang, dan hasil wawancara dengan isi dokumen (Moleong, 2004). Untuk mendukung hasil dari penelitian lapangan, peneliti juga menggunakan pendekatan studi kepustakaan dengan penelitian berbasis data sekunder. Studi kepustakaan merupakan teknik pengumpulan data dengan mengadakan studi penelaahan terhadap buku-buku, literatur-literatur, catatan-catatan, laporan-laporan yang ada kaitannya dengan masalah yang hendak dipecahkan (Nazir, 2009). 


\section{HASIL PENELITIAN DAN PEMBAHASAN}

Hidup menjadi anak jalanan memang bukan merupakan pilihan yang menyenangkan, karena mereka berada dalam kondisi yang tidak bermasa depan jelas, dan keberadaan mereka tidak jarang menjadi "masalah" bagi banyak pihak, keluarga, masyarakat dan negara. Namun, perhatian terhadap nasib anak jalanan tampaknya belum begitu besar dan solutif. Padahal mereka adalah bagian dari warga negara yang perlu dijamin hak-haknya, sehingga tumbuhkembang menjadi manusia dewasa yang bermanfaat, beradab dan bermasa depan cerah. Menurut UUD 1945, "anak terlantar itu dipelihara oleh negara." Artinya pemerintah mempunyai tanggung jawab terhadap pemeliharaan dan pembinaan anak-anak terlantar, termasuk anak jalanan.

Berdasarkan Peraturan Daerah No. 8 tahun 2007 tentang ketertiban umum Suku Dinas Sosial Kota Administrasi Jakarta Utara mempunyai tugas yang di dalamnya mencakup tentang penertiban, pembinaan dan pelayanan sosial, pemulangan PMKS, khususnya anak jalanan ke daerah asal. Peraturan Daerah yang dibuat dan dikeluarkan oleh Pemerintah Kota Jakarta Utara itu merupakan kebijakan publik. Dalam riset ini, penulis menggunakan dan mengadaptasi teori kebijakan yang dikemukakan oleh Edward III (1980) dalam melihat pelaksanaan Program Pelayanan Penyandang Masalah Kesejahteraan Sosial Anak Jalanan di Jakarta Utara. Setidaknya ada empat faktor yang mempengaruhi implementsi kebijakan yaitu faktor komunikasi, sumber daya, disposisi dan struktur birokrasi. Menilik pengaruh keempat faktor ini pada implementasi kebijakan program pelayanan penyandang masalah kesejahteraan sosial anak jalanan adalah sebagai berikut:

\section{Komunikasi}

Komunikasi merupakan penyampaian informasi kebijakan dari pembuat kebijakan kepada pelaksana kebijakan dan diefektifkan lagi dengan disampaikan juga kepada kelompok sasaran kebijakan serta pihak lain yang berkepentingan. Indikator dalam komunikasi yaitu proses transmisi/penyaluran komunikasi, kejelasan komunikasi dan konsistensi (Nurahmah, 2020). Aspek dari komunikasi ini berupa keputusan-keputusan kebijakan penanganan anak jalanan, petunjuk pelaksanaan, perintah dan lain-lain. Sehingga komunikasi yang terjadi berupa komunikasi internal dan komunikasi eksternal.Komunikasi internal terjadi antar pejabat Dinas Sosial yaitu pejabat struktural Dinas Sosial Provinsi dan Pejabat Unit

Pelaksana Teknis (UPT) berupa panti-panti, rumah singgah. Komunikasi internal ini disampaikan dalam bentuk formal seperti rapat dan non-formal seperti perintah langsung atasan terhadap bawahan. Komunikasi eksternal terjadi di antara pejabat UPT dengan anak jalanan. Dalam komunikasi ini bertujuan agar mereka mengetahui keadaan lapangan yang sesungguhnya, apa yang harus dipersiapkan dan dilaksanakan guna tujuan kebijakan penanganan anak jalanan agar dapat tercapai dan terwujud. Dalam komunikasi ini bertujuan agar mereka mengetahui keadaan lapangan yang sesungguhnya, apa yang harus dipersiapkan dan dilaksanakan guna tujuan kebijakan penanganan anak jalanan agar dapat tercapai dan terwujud. Arus komunikasi yang terjadi dalam implementasi kebijakan penanganan anak jalanan dapat dilihat sebagai berikut: 


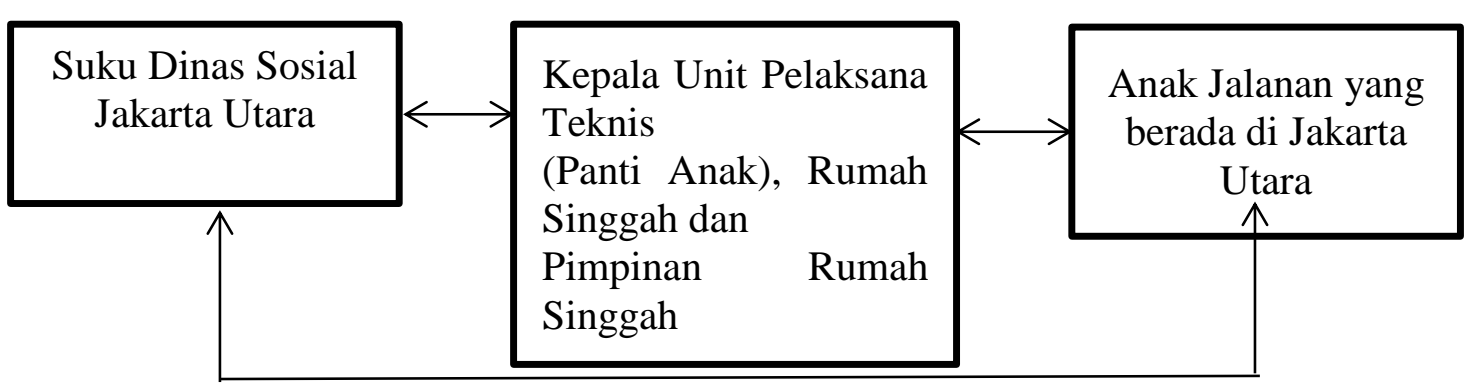

Gambar 1 Arus Komunikasi

Transmisi komunikasi dalam proses pelaksanaan kebijakan telah berjalan dengan baik. Hal ini ditunjukkan dengan birokrasi yang relatif pendek dalam penanganan anak jalanan. Sedangkan dalam konteks kejelasan komunikasi, temuan di lapangan menunjukkan kejelasan informasi yang dilakukan oleh pemerintah masih kurang. Hal ini ditandai dengan fakta sosialisasi yang belum jelas dan masih banyak anak jalanan yang belum mengetahui mengenai kebijakan penanganan anak jalanan tersebut.

Ketidakjelasakan komunikasi ini terjadi dikarenakan masih banyak masyarakat dan anak jalanan tentang program yang sedang diselenggarakan oleh pemerintah terutama dalam penanganan anak jalanan. Adapun mereka yang tahu itu hanya sebatas "sambil lalu" karena mendapat informasi tidak sengaja melalui pamflet atau dari aplikasi qlue. Oleh karena itu, titik tekannya masih permasalahan mendasar, yakni masih perlu adanya sosialisasi yang lebih giat agar kebijakan dapat tersampaikan kepada masyarakat maupun kepada anak jalanan (Diolah hasil wawancara dengan Kepala Seksi Rehabilitasi Sosial tanggal 25 April 2017).

Tingginya mobilitas dari para anak jalanan yang tidak menentu setiap harinya, telah disadari oleh Kepala Suku Dinas Sosial Kota Administrasi Jakarta Utara untuk membangun suatu posko pemantauan bagi para anak jalanan dan para Penyandang Masalah Kesejahtraan Sosial (PMKS) lainnya di Kota Administrasi Jakarta Utara. Posko untuk memantau anak jalanan dan Penyandang Masalah Kesejahteran Sosial (PMKS) di Kota Administrasi Jakarta Utara tersebut dibangun di enam titik di Kota Administrasi Jakarta Utara, yang meliputi:

1. Posko Mambo : Lampu Merah Enggano

2. Posko Kelapa Gading : Lampu Merah Summarecon

3. PoskoHailay Ancol : Lampu Merah Bintang Mas

4. Posko Penjaringan : Lampu Merah Gedong Panjang

5. Posko Plumpang : Pertigaan Plumpang Semper

6. Posko Coca Cola : Lampu Merah ITC Cempak Mas

Menurut peneliti, pembangunan posko pemantauan bagi para anak jalanan dan Penyandang Masalah Kesejahtraan Sosial (PMKS) di Kota Administrasi Jakarta Utara, merupakan suatu kebijakan yang tepat dari Kepala Suku Dinas Sosial Kota Administrasi Jakarta Utara. Posko pemantauan tersebut dapat dijadikan suatu tempat untuk mengumpulkan informasi yang dibutuhkan, seperti, mengenali berbagai macam aktifitas para anak jalanan di Kota Administrasi Jakarta Utara, mempererat hubungan kerjasama antara Suku Dinas Sosial Kota Administrasi Jakarta Utara dengan Lembaga Swadaya Masyarakat (LSM) yang menangani permasalahan anak jalanan di Kota Administrasi Jakarta Utara, dan menjadi tempat mengindentifikasi setiap permaslaahan anak jalanan guna menyeleksi pelayanan yang 
akan diberikan. Kebijakan Kepala Suku Dinas Sosial Kota Administrasi Jakarta Utara, menyangkut pembangunan posko pemantauan di 6 titik di Kota Administrasi Jakarta Utara peneliti lihat dari hasil observasi di lapangan telah memaksimalkan sesuai dengan semestinya, karena saat ini posko tersebut berisi petugas pemantau seperti yang telah ditentukan sebelumnya.

Hal penting selanjutnya dalam komunikasi yaitu konsistensi. Tentunya konsistensi diperlukan agar kebijakan yang diambil tidak simpang siur sehingga membingungkan pelaksana kebijakan, target group dan pihak-pihak yang berkepentingan. Perintah yang diberikan dalam pelaksanaan suatu komunikasi harus konsisten dan jelas, bila perintah yang diberikan sering berubah-ubah, maka dapat menimbulkan kebingungan bagi pelaksana di lapangan.

Proses komunikasi dalam pelaksanaan penanganan anak jalanan belum terlaksana dengan baik. Hal ini terjadi karena ada kondisi penyampaian informasi yang masih kurang efektif. Ada gap kemampuan pelaksana terhadap informasi kebijakan. Kondisi belum jelasnya komunikasi menyebabkan belum tercapainya perubahan yang diinginkan. Anak jalanan di Jakarta Utara masih banyak yang tidak mengetahui akan program tersebut.

\section{Sumber Daya}

Walaupun secara ideal isi kebijakan telah dikomunikasikan secara jelas dan konsisten, tetapi apabila implementor kekurangan sumber daya untuk melaksanakan, implementasi tidak akan berjalan efektif (Gumanti et al., 2020). Sumberdaya di sini bisa dimaknai sebagai hal-hal yang berkaitan dengan staff, information, authority, dan facilities (Edward III, 1980).

Pembahasan tentang staff diarahkan pada pembahasan kualitas pegawai-pegawai yang akan terlibat dalam pembuatan maupun pelaksanaan kebijakan. Membicarakan mengenai staff tidak hanya membicarakan soal angka saja karena keberhasilan implementasi kebijakan juga sangat dipengaruhi oleh kemampuan (kualitas) staff pelaksana. Oleh karenanya, dua aspek penting dalam menganalisa sumber daya dalam proses implementasi kebijakan publik, yaitu menganalisa size (ukuran) dan skills (kemampuan).

Tabel 2 Identitas Pegawai Menurut Tingkat Pendidikan

\begin{tabular}{|c|c|c|}
\hline No & Pendidikan & Jumlah \\
\hline 1. & SD & 1 Orang \\
\hline 2. & SMA & 18 Orang \\
\hline 3. & SMU & 1 Orang \\
\hline 4. & SMK & 1 Orang \\
\hline 5. & SI & 7 Orang \\
\hline 6. & S2 & 33 Orang \\
\hline \multicolumn{2}{|c|}{ Total } & \\
\hline
\end{tabular}

Sumber: Data diolah dari Suku Dinas Sosial Jakarta Utara (2017)

Berdasarkan tabel di atas diketahui bahwa pegawai terbanyak memiliki jenjang pendidikan SMA atau Sederajat dan Sarjana. Hal ini dapat mempengaruhi kualitas kinerja para pegawai dari sisi kemampuan professional dan keterampilan teknis para pegawai di Suku Dinas Sosial KotaAdministrasi Jakarta Utara. Sedangkan kualitas sumber daya manusia (aparatur) sangat diperlukan agar menajemen pemerintah dalam Suku Dinas Sosial Kota Administrasi Jakarta Utara dapat berlangsung secara efektif dan efesien, yang diperlukan tidak hanya jumlahnya yang cukup, tetapi juga kualitas para pegawai yang harus di ukur dengan melihat latar belakang pendidikan, keterampilan, pengalaman kerja, jenjang kepangkatan dan status kepegawaian. Dari 33 orang, efektif hanya ada 8 pegawai yang bertugas dalam penanganan Anak jalanan di Suku Dinas Sosial Kota Administrasi Jakarta Utara. Dari delapan orang tersebut, satu di antaranya adalah Kepala Seksi. Jadi jika Kepala 
Seksi tidak dihitung sebagai pelaksana lapang, maka anak jalanan dan PMKS se Jakarta Utara hanya akan ditangani oleh 7 orang saja (Diolah hasil wawancara dengan Kepala Seksi Rehabilitasi Sosial tanggal 25 April 2017).

Dengan pertimbangan kekurangan tenaga pelaksana, maka Kepala Seksi sekaligus bertindak sebagai pelaksana lapang dalam setiap operasi penjemputan anak jalanan dan penyerahan ke Panti Sosial. Kekurangan tenaga pula yang "memaksa" dilakukan kerja sama dengan Instansi Pemerintah seperti Kelurahan Kecamatan Sudin Tramtib Linmas Jakarta Utara. Tujuh orang tentu jumlah yang sangat tidak memadai untuk mengendalikan PMKS di enam kecamatan di wilayah Jakarta Utara. Apalagi Suku Dinas Sosial Kota Administrasi Jakarta Utara memiliki kepanjangan tangan (struktural) hingga ke tingkat kecamatan dan kelurahan.

Apabila kekurangan jumlah petugas lapangan bisa diatasi dengan meminta bantuan Sudin Tramtib Linmas Jakarta Utara serta Petugas P3S yang memiliki puluhan anggota P3S. Puluhan jumlah anggota Tramtib Linmas dan P3S Jakarta Utara belum termasuk anggota Tramtib Linmas yang ditempatkan di masing-masing kecamatan. Kekurangan tenaga juga dirasakan oleh panti sosial. Kurangnya tenaga pembina di panti sosial berjalan seiring dengan sedikitnya jumlah panti sosial untuk anak jalanan di Jakarta Utara, bahkan DKI Jakarta.

Selanjutnya, kekurangan tenaga pembinaan mengakibatkan pelayanan kepada anak jalanan dan PMKS pada umumnya tidak cukup memuaskan, baik dari segi kualitas maupun kuantitas. Dari sisi skills atau kemampuan pelaksana kebijakan, Suku Dinas Sosial Kota Administrasi Jakarta Utara tidak memiliki keluhan yang cukup substantif. Kemampuan penjemputan anak jalanan bukan kemampuan yang membutuhkan keahlian khusus. Artinya, penjemputan anak jalanan bisa dipelajari dengan cepat dan langsung dipraktikkan di jalanan. Keluhan mengenai skills justru muncul dari panti sosial.

Pelatihan yang diberikan panti sosial cenderung tidak memberikan alternatif alih profesi yang menarik bagi anak jalanan. Keterampilan dan pelatihan yang diberikan oleh petugas panti sosial terlalu usang untuk dijadikan alat mencari nafkah para mantan anak jalanan saat ini. Namun kurangnya skills ini bisa diatasi dengan bekerjasama dengan pihak lain dalam melakukan pelatihan. Kecenderungan yang mulai terlihat di beberapa instansi pemerintahan adalah melakukan kerja sama teknis dengan pihak lain untuk mengadakan kegiatan tertentu. Instansi pemerintah bertindak hanya sebagai penentu kegiatan dan penyandang dana. Dengan demikian, permasalahan skills petugas Panti Sosial bisa dialihkan menjadi masalah kecukupan anggaran.

Namun persoalannya dalam meningkatkan keterampilan petugas membutuhkan dana yang cukup besar; sementara rekrutmen petugas baru dalam jumlah cukup besar membutuhkan dana yang besar pula. Selain itu, direkrutnya petugas baru dengan ketrampilan tinggi memiliki konsekuensi pemberian gaji yang juga tinggi. Padahal standar gaji pegawai negeri masih terlalu sedikit, dan tidak sepadan, jika pegawai bersangkutan harus bekerja keras (penuh waktu) di panti sosial. Oleh karenanya alternatif langkah untuk mencapai perbaikan (kualitas) kemampuan petugas Panti Sosial adalah dengan mengharapkan skills upgrade terjadi secara alami melalui pengalaman dan rutinitas pekerjaan. Catatan dan kritik penting dari upgrading model ini yaitu, petugas menjadi orang terampil tapi tanpa membuka kemungkinan tercapainya inovasi baru. Kecil sekali kemungkinan muncul inovasi baru dalam pelayanan kepada anak jalanan jika petugas tidak diberi stimulus pengetahuan baru.

Sumberdaya authority membicarakan tentang hak dan kekuasaan untuk bertindak; kekuasaan membuat keputusan, memerintah, dan melimpahkan tanggung jawab kepada orang lain. Kebijakan penanganan anak jalanan memiliki struktur pelaksana bertingkat. Artinya terdapat beberapa jenjang instansi yang saling berhubungan, baik hubungan pertanggungjawaban secara vertikal maupun hubungan koordinasi secara horisontal. Kebijakan tidak akan bisa dilaksanakan bila tidak disertai pendelegasian kewenangan kepada pelaksana. 
Setiap tahap kegiatan penanganan anak jalanan yang dilakukan di Jakarta Utara telah disertai dengan kewenangan di antaranya yakni pada tahap perencanaan, kewenangan diberikan kepada Suku Dinas Sosial Kota Administrasi Jakarta Utaras dan Bappekodya Jakarta Utara. Sedangkan pada tahap pelaksanaan terdapat beberapa pihak yang diberi kewenangan berbeda yaitu Suku Dinas Sosial Kota Administrasi Jakarta Utara memiliki kewenangan hukum untuk menjemput anak jalanan, melakukan pendataan, kemudian mengirimkannya ke Panti Sosial. Suku Dinas Tramtib Linmas dan PSBIBD I dan PSBIBD II memiliki kewenangan untuk memberikan pelatihan, pembinaan dll. Pihak Kecamatan setempat memiliki kewenangan untuk menjemput anak jalanan yang berada di Wilayahnya. Sedangkan Polres, Polsek dan Satpol PP Jakarta Utara memiliki kewenangan untuk menangkap anak jalanan yang kemudian menyerahkannya kepada Suku Dinas Sosial Kota Administrasi Jakarta Utara. Pihak-pihak tersebut hanya memiliki kewenangan menangani jika terjadi campur tangan oknum militer atau polisi saat penjemputan anak jalanan berada di jalanan atau tempat-tempat umum.

Pada tahap pemantauan, kewenangan berada di tangan Suku Dinas Sosial Kota Administrasi Jakarta Utara, sedangkan tahap evaluasi, kewenangan berada pada Suku Dinas Sosial Kota Administrasi Jakarta Utara. Selanjutnya pada tahap pembinaan anak jalanan, kewenangan untuk melakukan pendataan, pemilahan, dan pembinaan terhadap anak jalanan berada pada Panti Sosial. Berikut ini merupakan uraian kegiatan monitoring dan evaluasi yang menjadi bagian dalam penanganan anak jalanan di Kota Administrasi Jakarta Utara tersebut:

1. Kunjungan terhadap shelter-shelter yang dijadikan sebagai tempat pemberdayaan anak jalanan

2. Kunjungan kepada keluarga dan masyarakat yang merupakan tempat tinggal anak jalanan

3. Fasilitasi pertemuan pada tingkat komunitas masyarakat

Uraian kegiatan monitoring dan evaluasi yang dilaksananakan oleh Kepala Suku Dinas Sosial Kota Administrasi Jakarta Utara, menurut peneliti sudah cukup tepat, karena monitoring dan evaluasi tersebut menjadi suatu jembatan bagi Kepala Suku Dinas Sosial Kota Administrasi Jakarta Utara untuk melihat sejauh mana tingkat pelaksanaan kegiatan pemberdayaan yang dilaksanakan oleh Panti Sosial dan rumah-rumah perlindungan anak. Dari uraian mengenai kewenangan yang dimiliki masing-masing pelaksana kebijakan

Selanjutnya sumberdaya yang dibahas adalah tentang fasilitas. Kelemahan paling mencolok dari pelaksanaan kebijakan penanganan Anak jalanan ini adalah jauhnya fasilitas dari memadai. Kendaraan operasional penjemputan yang dimiliki Suku Dinas Sosial Kota Administrasi Jakarta Utara hanyalah 2 mobil gerandong (seperti mobil tahanan) dan 1 mobil panter. Mobil tersebut merangkap juga sebagai mobil operasional harian Seksi Rehabilitasi Sosial, untuk sementara kebutuhan kendaraan pada saat penjemputan anak jalanan dari jalanan dan tempat-tempat umum masih bisa diatasi dengan bantuan mobil Tramtib Linmas dan mobil Suku Dinas Sosial Kota Administrasi Jakarta Utara.

Fasilitas Panti Sosial, terutama dari sisi kuantitas, ternyata jauh dari memadai. DKI Jakarta memiliki banyak Panti Sosial, namun di seluruh Wilayah DKI Jakarta hanya ada dua Panti Sosial yang diperuntukkan bagi penampungan sementara yaitu Panti Sosial Bina Bangun Daya 2 Cipayung Jakarta Timur dan Panti Sosial Bina Bangun Daya 1 Kedoya Jakarta Barat dan pembinaan anak jalanan, yaitu Panti Sosial Putra Utama Satu, Panti Sosial Putra Utama Dua, Panti Sosial Putra Utama Tigayang tersebar di Jakarta. Daya tampung ketiga panti sosial yang masing-masing berkisar pada angka 120 orang, tentu tak sepadan dengan ratusan, bahkan ribuan, anak jalanan yang ada di seluruh wilayah DKI Jakarta. 
Kurangnya fasilitas, terutama daya tampung panti sosial, membuat anak jalanan masih banyak dijumpai di jalanan. Perlu digarisbawahi bahwa penyebab banyaknya jumlah anak jalanan yang berada di jalanan, selain karena tidak semua anak jalanan bisa dijemput dan dikirim ke panti sosial yang daya tampungnya terbatas, adalah terjadinya migrasi anak jalanan yang sulit dibendung. Menurut pengakuan Suku Dinas Sosial Kota Administrasi Jakarta Utara menghentikan migrasi anak jalanan adalah hal yang paling tidak bisa dilakukan. Sepanjang yang diketahui, Pemkot Jakarta Utara tidak pernah mengeluarkan kebijakan untuk menahan/menghentikan arus migrasi anak jalanan. Perbatasan Jakarta terlalu luas untuk bisa diawasi setiap saat, sehingga anak jalanan tetap bisa melakukan perpindahan lintas batas secara sporadis.

Menurut pengakuan Suku Dinas Sosial Kota Administrasi Jakarta Utara menghentikan migrasi anak jalanan adalah hal yang paling tidak bisa dilakukan. Sepanjang yang diketahui, Pemkot Jakarta Utara tidak pernah mengeluarkan kebijakan untuk menahan/menghentikan arus migrasi anak jalanan. Perbatasan Jakarta terlalu luas untuk bisa diawasi setiap saat, sehingga anak jalanan tetap bisa melakukan perpindahan lintas batas secara sporadis.

\section{Disposisi}

Disposisi merupakan kemauan, keinginan dan kecenderungan para pelaku untuk melaksanakan kebijakan secara sungguh-sungguh sehingga apa yang menjadi tujuan kebijakan dapat diwujudkan (Edward III, 1980). Kecenderungan perilaku atau karakteristik ini berhubungan dengan respon para pelaksana kebijakan di dalam penanganan anak jalanan ini apakah mereka mendukung atau menolak kebijakan anak jalanan di Jakarta Utara.

Hasil riset menunjukkan bahwa para pelaksana kebijakan memiliki respon yang belum optimal dalam menjalankan kebijakan anak jalanan di Jakarta Utara. Dalam arti, secara normatif, para pelaksana telah menjalankan kebijakan tersebut, namun belum tampak sungguh-sungguh bila dilihat dari perspektif "tujuan kebijakan" karena faktor sumberdaya yang masih terbatas. Hal yang perlu dilihat dari disposisi adalah tentang karakteristik dari para pelaksana itu sendiri. Salah satu karakteristik birokrat tersebut adalah berkenaan dengan perilakunya. Ada beberapa perilaku yang relevan dibahas dalam konteks birokrat sebagai agensi pelaksana di antaranya kurangnya kesadaran bahwa hal yang diurus adalah manusia yang memiliki kompleksitas permasalahan dan kedua yaitu asumsi bahwa semua hal memiliki karakteristik yang sama. Kedua asumsi tersebut membuat birokrat melayani anak jalanan dengan cara yang kurang bijaksana.

\section{Struktur Birokrasi}

Hal substantif yanng perlu dibahas ketika membicarakan struktur birokrasi dalam pelaksanaan kebijakan publik adalah standard operating procedures (SOP) dan fragmentation (Edward III, 1980). Secara formil, Suku Dinas Sosial Kota Administrasi Jakarta Utara dan Panti Sosial telah memiliki SOP. Selama ini panduan yang dipergunakan oleh Suku Dinas Sosial Kota Administrasi Jakarta Utara dan Panti Sosial dalam menangani anak jalanan adalah Peraturan Menteri Sosial Republik Indonesia Nomor 30/Huk/2011 tentang Standar Nasional Pengasuhan Anak Untuk Lembaga Kesejahteraan Sosial Anak dengan beberapa penambahan dan pengurangan yang dikontekstualisasi dengan kondisi Jakarta Utara.

Cara penanganan anak jalanan bisa disesuaikan dengan kondisi riil yang dihadapi. Penjemputan anak jalanan yang berada di jalanan menjadi lebih fleksibel karena selalu terbuka kemungkinan untuk melajukan revisi aturan sewaktu-waktu. Fleksibilitas dalam menghadapi anak jalanan akan sulit dilakukan jika aturan/petunjuk teknis bersifat baku/formal/tertulis. Dalam pelaksanaannya, seperti telah dibahas sebelumnya, pelaksanaan kebijakan penanganan anak jalanan di Jakarta Utara diserahkan kepada aktor utama yaitu 
Suku Dinas Sosial Kota Administrasi Jakarta Utara dan Panti Sosial. Suku Dinas Sosial Kota Administrasi Jakarta Utara melakukan koordinasi dengan berbagai instansi lain untuk melakukan penjemputan terhadap anak jalanan yang berada di jalanan. Sementara Panti Sosial berperan sebagai pihak yang menampung anak jalanan dan melakukan pembinaan terhadapnya.

Terkait dengan fragmentation, pelaksanaan kebijakan penanganan anak jalanan di Jakarta Utara tidak mengalami fragmentasi. Di lapangan tidak terjadi fragmentasi koordinasi pelaksanaan kebijakan dan pemecahan pertanggungjawaban. Dalam pelaksanaan kebijakan tersebut tidak terjadi pemecahan koordinasi pelaksanaan kebijakan dan pemecahan pertanggungjawaban. Meskipun praktek di lapangan menunjukkan banyak pihak yang terlibat penanganan anak jalanan, namun puncak-puncak koordinasi dan pertanggungjawaban pelaksanaan tetap berada di tangan Suku Dinas Sosial Kota Administrasi Jakarta Utara dan Panti Sosial. Pihak-pihak selain Suku Dinas Sosial Kota Administrasi Jakarta Utara dan Panti Sosial yang terlibat dalam penanganan anak jalanan bertindak hanya atas permintaanSuku Dinas Sosial Kota Administrasi Jakarta Utara dan karena itu tidak memiliki kewenangan dan pertanggungjawaban khusus berkaitan dengan penanganan anak jalanan. Satu-satunya hal yang mengganggu dalam kaitannya dengan fragmentation, meskipun selama ini tidak menghambat pelayanan yang diberikan adalah koordinasi antarinstansi pascapenjemputan anak jalanan yang berada di jalanan.

Terdapat beberapa instansi yang memiliki kewenangan untuk menjemput anak jalanan, dengan berbagai alasan, dari jalanan dan menyerahkannya kepada panti sosial. Kemudian di panti sosial melakukan pendataan anak jalanan, asal wilayah penjemputan, dan instansi yang menjemputnya. beberapa instansi yang memiliki kewenangan menjemput anak jalanan yang berada di jalanan, kadang-kadang bersikap "arogan" dan tidak merasa perlu berkoordinasi dengan instansi lain, terutama Suku Dinas Sosial Kota Administrasi Jakarta Utara, alasan yang dikemukakan masing-masing instansi memang bisa diterima, masingmasing instansi tidak berkoordinasi dengan Suku Dinas Sosial Kota Administrasi Jakarta Utara karena memiliki tugas sendiri yang juga berlandasan hukum.

Walaupun banyak pihak yang terlibat penanganan anak jalanan, namun puncakpuncak koordinasi dan pertanggungjawaban pelaksanaan tetap berada di tangan Suku Dinas Sosial Kota Administrasi Jakarta Utara dan Panti Sosial. Sedangkan pihak-pihak selain Suku Dinas Sosial Kota Administrasi Jakarta Utara dan Panti Sosial yang terlibat dalam penanganan anak jalanan bertindak hanya atas permintaan Suku Dinas Sosial Kota Administrasi Utara dan karena itu tidak memiliki kewenangan dan pertanggungjawaban khusus berkaitan dengan penanganan anak jalanan. Adapun yang relatif menjadi kendala dalam kaitannya dengan fragmentasi adalah koordinasi antar instanasi pasca penjemputan anak jalanan. Hal ini terjadi karena pihak-pihak yang memiliki kewenangan dalam penjemputan memiliki argumentasi yang bisa diterima dan berlandaskan hukum tertentu. Contohnya Tramtib Linmas yang memiliki kewenangan untuk menjaga ketertiban di wilayah Jakarta Utara. Dalam praktiknya, Tramtib Linmas tidak perlu melakukan koordinasi dengan Suku Dinas Sosial Kota Administrasi Jakarta Utara.

\section{SIMPULAN}

Dari hasil studi sebelumnya, secara garis besar terdapat empat kesimpulan umum yang saling berkaitan, yaitu 1) Proses komunikasi dalam pelaksanaan penanganan anak jalanan belum terlaksana dengan baik. Hal ini terjadi karena ada kondisi penyampaian informasi yang masih kurang efektif. Ada gap kemampuan pelaksana terhadap informasi kebijakan. Selanjutnya, 2) Sumberdaya yang berkaitan dengan staff, information, authority, dan facilities juga masingmasing memiliki kekurangan sehingga kekurangan efektivitas dalam hal sumberdaya kebijakan. Kemudian, 3) Dalam konteks disposisi menunjukkan bahwa respon dari pemerintah Jakarta Utara belum optimal. Sedangkan dari 4) stuktur birokrasi, Suku Dinas 
Sosial Kota Administrasi Jakarta Utara dan Panti Sosial telah memiliki SOP tersendiri. Kemudian dalam stukrur birokrasi, pelaksanaan kebijakan penanganan anak jalanan di Jakarta Utara tidak mengalami fragmentasi. Di lapangan tidak terjadi fragmentasi koordinasi pelaksanaan kebijakan dan pemecahan pertanggungjawaban.

\section{DAFTAR PUSTAKA}

Astri, H. (2014). Kehidupan anak jalanan di Indonesia: faktor penyebab, tatanan hidup dan kerentanan berperilaku menyimpang. Jurnal Aspirasi, 5(2), 145-155.

Azmiyati, S. R. (2014). Gambaran Penggunaan Napza Pada Anak Jalanan Di Kota Semarang. Kemas: Jurnal Kesehatan Masyarakat, 9(2), 137-143. https://doi.org/https://doi.org/10.15294/kemas.v9i2.2841

Edward III, G. C. (1980). Implementing Public Policy. Congressional Quarterly Press.

Gumanti, L., Permana, I., \& Sutarjo, M. (2020). Implementasi Kebijakan Program Pembinaan Anak Jalanan di Dinas Sosial Kabupaten Cirebon. Jurnal Ilmiah Publika, 8(1), 9-15.

Khoirunnisa, Ratna, E., \& Irawati. (2020). Perlindungan Hukum Anak Terlantar Atas Hak Anak Mendapatkan Jaminan Kesehatan. Notarius, 13(1), 546-556.

Mambang, \& Wahyudi, H. (2016). Implementasi Kebijakan Gelandangan, Pengemis, Tuna Susila dan Anak Jalanan di Kota Palangka Raya Provinsi Kalimantan Tengah. Pencerah Publik, 3(2), 1-8.

Moleong, L. J. (2004). Metode Penelitian Kualitatif. PT. Remaja Rosdakarya.

Nazir, M. (2009). Metode Penelitian. Ghalia Indonesia.

Nurahmah, J. A. (2020). Implementasi Kebijakan Peraturan Daerah Nomor 14 Tahun 2017 Dilihat Dari Aspek Komunikasi Pada Dinas Lingkungan Hidup Kabupaten Tabalong. JAPB: Jurnal Administrasi Publik Dan Bisnis, 3(2), 1016-1030.

Suleman, S., Pakaya, R., \& Daud, Y. (2019). Pendataan Penyandang Masalah Kesejahteraan Sosial (Pmks) Berbasis Web. Jurnal Teknologi Informasi Indonesia, 4(1), 30-39.

Suyanto, B. (2013). Masalah Sosial Anak. Kencana Pranada Media Group.

Winarno, B. (2008). Kebijakan Publik Teori \& Proses. MedPress. 


\section{(A) Check for updates \\ Peran World Health Organization dalam Menangani Isu Female Genital Mutilation di Sierra Leone}

\begin{tabular}{|c|c|}
\hline & \\
\hline $\mathrm{el}$ & \multirow{4}{*}{$\begin{array}{l}\text { ABSTRAK } \\
\text { Abstract This study describes the role of WHO in explaining the issue of Female Genital } \\
\text { Mutilation in Sierra Leone. In this study, this study discusses the role of WHO through } \\
\text { CEDAW and the Maputo Protocol which has been ratified by Sierra Leone in the } \\
\text { implementation of FGM practices that involve the culture of the Sierra Leone community } \\
\text { for women's processes to drive international movements and activities. FGM culture itself } \\
\text { is a form against women. This study uses a qualitative method, with a descriptive analytic } \\
\text { approach, where data are collected by literature study. In explaining this research, the } \\
\text { researcher obtained data through journals, books, theses, scientific reports, the internet } \\
\text { and government reports as well as international organization responses submitted to } \\
\text { FGM in Sierra Leone. Theories used are human rights, international organizations and } \\
\text { roles. The data obtained are then classified and analyzed using the theory used to draw } \\
\text { conclusions. From the results of the analysis, the researchers concluded that the } \\
\text { application of cedaw by the Sierra Leone government on the issue of eliminating Female } \\
\text { Genital Mutilation not implemented well by the Sierra Leone government because the } \\
\text { government does not include laws governing national laws related to the implementation } \\
\text { of traditional agreements involving FGM. The government's reason is feared as its } \\
\text { national interest. }\end{array}$} \\
\hline $\begin{array}{l}0 \\
1\end{array}$ & \\
\hline gantza & \\
\hline Istus & \\
\hline
\end{tabular}

\section{Email:}

ardli.johan@yahoo.com

Abstrak Penelitian ini menjelaskan tentang peran WHO dalam menangani isu Female Genital Mutilation di Sierra Leone. Dalam penelitian ini peneliti berfokus pada implementasi peran WHO melalui CEDAW dan Maputo Protocol yang telah diratifikasi oleh Sierra Leone dalam penghapusan praktek FGM yang merupakan budaya dari masyarakat Sierra Leone untuk proses wanita menuju dewasa serta gerakan dari aktivisi internasional dan organisasi internasional yang berfokus pada penghapusan praktik FGM. Budaya FGM sendiri merupakan salah satu bentuk diskriminasi terhadap perempuan. Penelitian ini menggunakan metode kualitatif, dengan pendekatan deskriptif analitik, dimana data-data yang dikumpulkan dengan menggunakan studi pustaka. Dalam menjelaskan penelitian ini Peneliti memperoleh data melalui Jurnal, Buku, Tesis, Laporan Ilmiah, internet dan laporan pemerintah serta respon organisasi internasional yang berfokus pada FGM di Sierra Leone. Teori yang digunakan adalah HAM, Organisasi Internasional dan Peran. Data-data yang diperoleh kemudian diklasifikasikan untuk kemudian dianalsis dengan menggunakan teori yang digunakan untuk menarik kesimpulan. Dari hasil analisi, peneliti mengambil kesimpulan bahwa implementasi CEDAW oleh pemerintah Sierra Leone dalam masalah penghapusan Female Genital Mutilation tidak diterapkan secara baik oleh pemerintah Sierra Leone dikarenakan pemerintah tidak memasukan undang-undang kedalam hukum nasionalnya mengenai penghapusan praktik tradisional berbahaya yaitu FGM. Alasan pemerintah adalah

DOI:

https://doi.org/10.33019/jpi.v2i 2.41 dikhwatirkan mengancam kepentingan nasionalnya.

\section{Tentang:}

\section{Lisensi:}

Ardli Johan Kusuma, menyelesaikan studi S3 pada prodi Ilmu Politik - Politik Islam di Universitas Muhammadiyah Yogyakarta pada tahun 2020. Saat ini penulis merupakan dosen tetap di Jurusan Ilmu Hubungan Internasional Universitas 17 Agustus 1945 Jakarta, dengan fokus kajian terkait isu-isu HAM, Human Security, dan Terorisme.

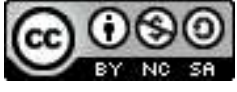

Attribution-NonCommercialShareAlike 4.0 International (CC-BY-NC-SA 4.0)
Isabella Putri Maharani, mendapatkan gelar sarjana pada prodi Ilmu Hubungan Internasional Universitas 17 Agustus 1945 Jakarta pada tahun 2020. 


\section{PENDAHULUAN}

Kepercayaan bahwa negara ialah satu-satunya aktor yang dapat menyelesaikan fenomenafenomena yang terjadi di masyarakat mulai pudar setelah berakhirnya Perang Dunia ke II. Kondisi dunia internasional mulai berubah pasca perang dunia II, dimana mulai muncul aktor selain negara yang berperan juga untuk mengatasi kasus fenomena-fenomena yang terjadi di dunia internasional, yakni Organisasi Internasional. Organisasi Internasional dibagi menjadi dua tipe yaitu International Governmental Organization (IGO) seperti United Nations, North Atlantic Treaty Organization (NATO), dan International Monetary Fund (IMF) serta NonGovernmental Organizations (NGO) seperti Amnesty International dan International Redcross.

Organisasi-organisasi internasional mulai memberikan peran yang signifikan pada fenomena-fenomena sosial yang terjadi di masyarakat karena memiliki rasa tanggung jawab atas masyarakat. Masing-masing dari organisasi internasional memiliki konsentrasi isu tersendiri seperti kebudayaan, kelestarian lingkungan, kesehatan, dan semua isu-isu sosial yang dihadapi oleh masyarakat. Salah satu contoh dari organisasi internasional yang memiliki bidang pergerakan yang spesifik adalah World Health Organization (WHO), dimana organisasi ini secara khusus mengurusi masalah kesehatan.

WHO ialah organisasi internasional dibawah naungan United Nations yang bergerak di bidang kesehatan yang bermisi menjamin kesehatan dunia serta memberikan laporan secara rutin mengenai angka kesehatan dari suatu negara. Salah satu isu yang menjadi perhatian WHO untuk ditangani ialah FGM (Female Genital Mutilation) di Sierra Leone. Hal ini disebabkan oleh tingginya angka persentase perempuan yang menjalani FGM. Data menunjukkan bahwa perempuan berusia 15 hingga 49 tahun yang mengalami atau menjalni FGM di Sierra Seone mencapai angka 90 persen. Tinggnya angka tersebut membuat WHO memberikan perhatian untuk menangani fenomena yang terjadi terkait praktik FGM tersebut (UNICEF, 2016). Berdasarkan Fact Sheet No. 23, Harmfull Traditional Practices Affecting the Health of Women and Children (Nations, 1995) yang dikeluarkan oleh Office of the High Commissioner for Human rights, FGM (Female Genital Mutilation) adalah istilah yang dipakai untuk mengacu pada tindakan pembedahan untuk mengangkat sebagian atau seluruh bagian organ genital perempuan yang paling sensitif (Refworld, 2020)

FGM (Female Genital Mutilation) atau FGC (Female Genital Cutting) adalah segala prosedur atau tindakan yang ditujukan untuk menghilangkan sebagian atau seluruh organ genital luar dari wanita atas nama budaya, adat, agama atau alasan-alasan lain di luar alasanalasan kesehatan atau penyembuhan. Praktik FGM (Female Genital Muilation) telah berlangsung lebih di 100 kelompok etnis yang berada di 40 lebih negara di Afrika, Timur Tengah, Amerika bagian selatan, Asia dan Australia. Kebanyakan dari praktik FGM (Female Genital Mutilation) di dunia dilakukan di 28 negara Afrika diantaranya yang terbesar yaitu Djibouti, Etrirea, Sierra Leone, Somalia, dan Sudan dimana sekitar 90\% perempuannya mengalami praktik ini (Anadia, 2017). 


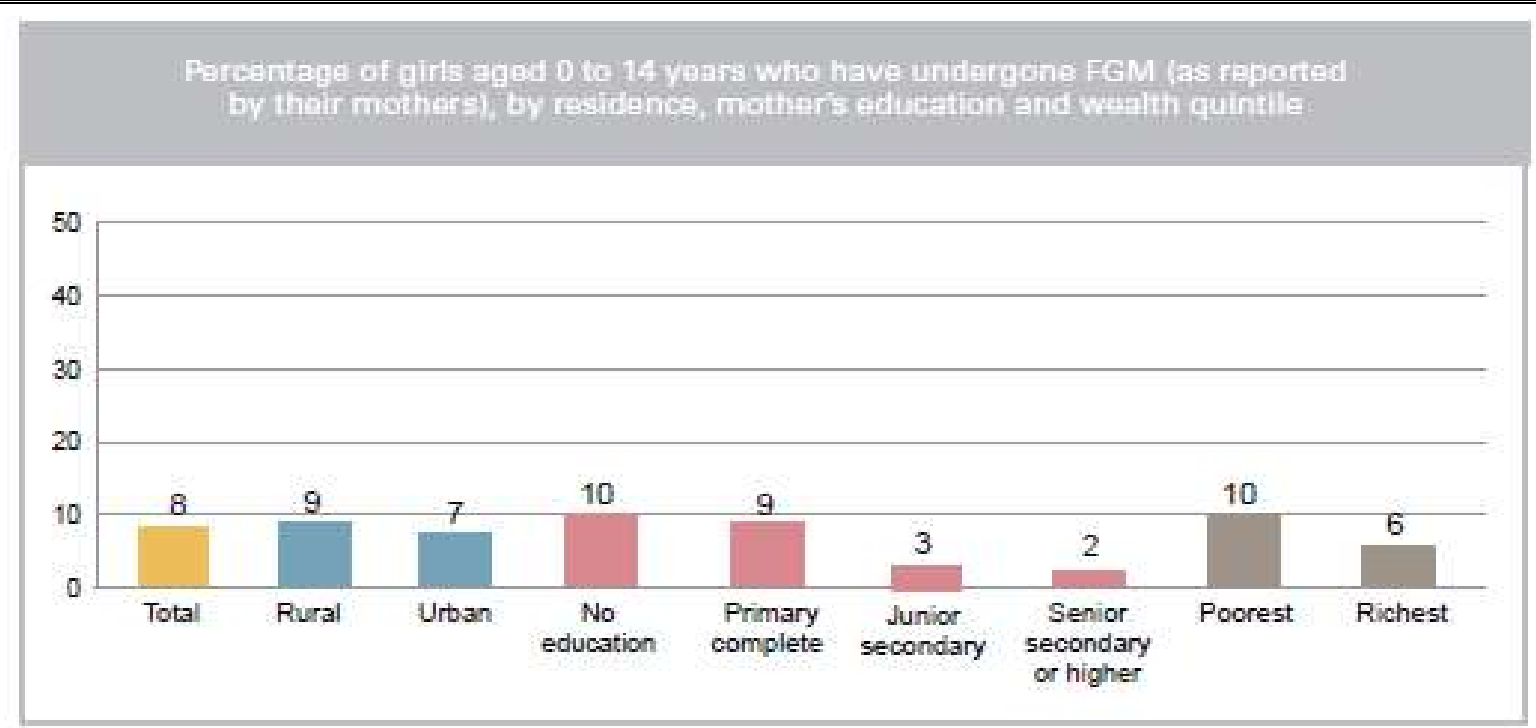

Sumber:UNICEF 2017

\section{Gambar 1 Persentase Anak Perempuan Berusia 0 Hingga 14 Tahun yang telah Menjalani FGM Berdasarkan Tempat Tinggal, Pendidikan dan Kelas Sosial di Sierra Leone}

Praktek ini mulai dari adanya konsekuensi medis seperti pendarahan dan infeksi bahkan dapat menyebabkan kematian. Hal ini dipicu oleh penggunaan alat alat pemotongan yang tidak higenis atau bahkan bukan alat alat sunat pada umumnya atau cenderung menggunakan alat-alat yang bersifat tradisional seperti pecahan kaca, batu yang tajam atau bahkan besi yang runcing. Selain alat-alat yang bersifat tradisional banyak kegiatan khitan perempuan ini dilaksanakan saat acara adat dimana tidak memadainya fasilitas Kesehatan (WHO, 2020).

WHO sebagai organisasi internasional yang fokus pada isu kesehatan, tentunya memiliki kepentingan dalam penanganan masalah FGM di Sierra Leone. Terlebih lagi angka persentase perempuan yang mengalami FGM di Seierra Leone sangat tinggi yaitu mencapai angka 90 persen. Tetapi pada kenyataanya, masalah FGM di negara tersebut masaih saja dipraktikkan oleh masyarakatnya, bahkan seolah-olah, pemerintah Sierra Leone tidak berkontribusi terhadap masalah yang terjadi dan terkesan membiarkan fenomena tersebut. Untuk itu penting kiranya untuk diteliti terkait peran yang dilakukan oleh WHO sebagai organisasi kesehatan dunia dalam penanganan kasus tersebut. Untuk itu penelitian ini berupaya untuk menjawab pertanyaan terkait bagaimana peran WHO dalam menangani masalah FGM di Sierra Leone.

\section{METODE PENELITIAN}

Penelitian ini menggunakan metode kualitatif, dimana menurut John W. Creswell penelitian kualitatif dimaknai sebagai metode-metode untuk mengeksplorasi dan memahami makna dari suatu fenomena yang dianggap bahwa fenomena tersebut berasal dari masalah sosial atau kemanusiaan (Creswell, 2010). Penelitian ini menggunakan data-data sekunder, dengan menggunakan pendekatan studi literatur, dimana data-data diperoleh dari berbagai sumbers litaretur seperti: Jurnal, Buku, Tesis, Laporan Ilmiah, internet dan laporan pemerintah serta respon organisasi internasional yang berfokus pada FGM di Sierra Leone. Dalam penelitian kualitatif, penjabaran atas langkah-langkah analisa data dan penjelasan peneliti atas data yang dikumpulkan penting dalam memastikan bahwa data tersebut bersifat valid. Analisis data dilakukan melalui proses keberkelanjutan yang dengan melakukan refleksi secara terus-menerus terhadap data, serta mengajukan pertanyaan-pertanyaan ana-litis, yang dilanjutkan dengan menulis catatan singkat sepan-jang penelitian, untuk mendapatkan hasil analitis dari data yang diperoleh. Metode kualitatif ini menghasilkan data yang 
deskriptif menurut analisa serta fakta yang ada dari subjek atau objek yang diamati (Creswell, 2010).

Penelitian kualitatif juga merupakan penelitian yang bersifat interpretatif. Interpretatif berarti penulis menyertakan pendapatnya berdasarkan pengertian yang telah diperoleh setelah pengkajian data. Dalam menjawab pertanyaan penelitian, jenis penelitian yang digunakan peneliti untuk menyusun penelitian ini adalah Deskriptif Analitis untuk mengetahui hubungan antar unsur yang terkait dengan bagaimana peran WHO dalam penghapusan praktik FGM (Female Genital Mutilation) di Sierra Leone. Pengertian dari penelitian deskriptif analitis itu sendiri merupakan penelitian yang melibatkan penjabaran unsur-unsur di dalam pokok permasalahan yang kemudian akan dipersatukan dengan hubungan antar unsur tersebut.

\section{HASIL PENELITIAN DAN PEMBAHASAN}

Dalam konteks pola hubungan internasional modern, negara bukanlah aktor tunggal. Mengingat semakin kompleksnya fenomena permasalahan yang terjadi dalam dunia internasional, sehingga dalam kasus-kasus tertentu justru peran negara harus didukung dengan adanya peran dari aktor non-negara seperti organisasi internasional baik yang dalam bentuk Interational Governmental Organization (IGO) ataupun International NonGovernmental Organizations (INGO) dalam penanganan masalah-masalah yang terjadi di dunia internasional (Kusuma \& Sitorus, 2019). Terlebih lagi masalah yang berkaitan dengan kesehatan di suatu masyarakat memiliki kompleksitas yang cukup rumit. Karena masalah kesehatan pada suatu masyarakat berkaitan dengan budaya kehidupan masayarakat, serta rendahnya pengetahuan tentang ancaman kesehatan yang dihadapi (Saputri \& Tumangger, 2019). Rendahnya pengetahuan tentang kesehatan ini tidak hanya dialami oleh masyarakat awam, tetapi pada kasus-kasus tertentu, tenaga medis juga memiliki pengetahuan dan kesadaran yang minim tentang suatu ancaman kesehatan karena adanya kebudayaan dan keyakinan yang melekat dalam suatu masyarakat. Dalam konteks ini, WHO sebagai organisasi kesehatan internasional tentunya memiliki perananan yang sangat penting dalam penyelesaian masalah FGM yang terjadi di dunia, termasuk yang terjadi di Sierra Leone.

Konsep peranan dalam terminologi hubungan internasional merupakan sebagai sebuah penjelasan mengenai prilaku aktor internasional baik individu maupun organisasi yang dipahami dalam suatu tatanan sistem internasional. Konsep teori peranan pertama kali dikembangkan di dalam ilmu sosiologi. Peranan merupakan aspek dinamis dalam kedudukan (status) atau perilaku yang diharapkan dari seseorang yang punya status. Jika seseorang atau lembaga melaksanakan hak dan kewajibannya sesuai dengan posisi atau kedudukannya, maka seseorang/lembaga telah menjalankan suatu peranan (role).

Sementara itu, fungsi dari Organisasi Internasional sendiri menurut A.Le Roy Bannet (Satrio, 2008) adalah:

1. Menyediakan hal-hal yang dibutuhkan bagi kerjasama yang dilakukan antar Negara dengan tujuan menghasilkan keuntungan yang besar bagi seluruh bangsa.

2. Memperbanyak saluran komunikasi antar pemerintahan, sehingga ketika masalah muncul ke permukaan, ide-ide dapat bersatu.

WHO sendiri merupakan bagian dari PBB yang merupakan organisasi internasional antar pemerintah negara terbesar di dunia. Organisasi internasional ini memiliki peran sangat penting dalam setiap penyelesaian masalah-masalah yang terjadi di dunia internasional, terutama yang berkaitan dengan isu kesehatan. Jika dilihat secara konseptual, organisasi internasional memiliki beberapa peran dalam menangani suatu masalah yang terjadi di dunia internasional, diantaranya peran sebagai Inisiator, Fasilitator, Determinator, dan Mediator (Aprinanda, 2016). 
1. Inisiator

Sebagai inisiator, organisasi internasional akan melakukan peranan dalam bentuk memprakarsai kerja sama serta mengajukan suatu masalah maupun fenomena pada komunitas internasional untuk mencari solusi terhadap hal tersebut. Bentuk kerja sama ini dapat dilakukan dengan negara, organisasi, masyarakat/komunitas hingga individu.

2. Fasilitator

Sebagai fasilitator, peranan yang dilakukan organisasi internasional adalah upaya untuk menyediakan fasilitas yang dibutuhkan untuk menyelesaikan masalah dan mencapai tujuan organisasi.

3. Determinator

Peranan organisasi internasional sebagai determinator adalah upaya dari organisasi internasional dalam memberi dan mengambil keputusan pada suatu masalah.

4. Mediator/rekonsiliator

Sebagai mediator/rekonsiliator, organisasi internasional akan melakukan peranan sebagai penengah guna menyelesaikan masalah atau konflik yang terjadi di antara anggotanya.

Peranan dari organisasi internasional, dalam hal ini WHO merupakan kebutuhan pokok dalam penanganan masalah FGM di seluruh dunia termasuk di Sierra Leone. Adapun bentuk peranan yang dilakukan oleh WHO dalam penanganan FGM khsususnya yang terjadi di Sierra Leone, yang sesuai dengan konseptual peranan organisasi internasional, WHO hanya menjalankan tiga dari empat peranan organisasi internasional, yaitu peran sebagai Inisiator, Fasilitator, dan Determinator. Hal ini terjadi karena peran sebagai Mediator tidak mungkin dilakukan oleh WHO dalam penangnan masalah FGM di Sierra Leone. Peran sebagai Mediator dapat dijalankan ketika terjadi konflik antar anggota organisasi. Sementara kasus FGM ini bersifat internal negara anggor, sehingga WHO hanya bisa menjalankan tiga dari empat peran yang bisa dijalankan oleh organisasi internasional. adapun penjelasan tentang tiga peran tersebut antara lain adalah:

WHO Sebagai Fasilitator WHO sebagai organisasi internasional telah menjalankan perannya sebagai Fasilitator dalam menangani isu FGM di Sierra Leone. WHO khususnya dan United Nations pada umumnya telah mendukung penuh penghapusan FGM atas segala pertimbangan tentang konsekuensi yang berbahaya bagi perempuan dan anak perempuan yang menjadi korban FGM. Selama beberapa tahun, pemerintah Sierra Leone didukung oleh PBB, dan telah berinvestasi dalam menyusun Strategi Nasional untuk mengurangi FGM yang dapat membantu menerjemahkan komitmen internasional yang telah disepakati oleh negara tersebut ke dalam tindakan praktis. Rancangan strategi telah ditulis setelah dilakukan konsultasi ekstensif dengan pemerintah, Kepala Paramount, pemimpin agama, Soweis, kelompok masyarakat sipil, dan NGOs (UNFPA, 2017).

Sejalan dengan upaya Pemerintah untuk menegakkan semua hak asasi perempuan, laki-laki, anak laki-laki dan perempuan di Sierra Leone, Pemerintah didorong dengan cepat untuk menyelesaikan rancangan strategi nasional dan mengimplementasikannya, dengan tujuan untuk memfasilitasi pendidikan publik dan keterlibatan masyarakat untuk mengakhiri praktik berbahaya FGM (UNFPA, 2017).

WHO Sebagai Determinator Salah satu bentuk perhatian PBB ialah dengan menghasilkan Convention on the Elimination of all Forms of Discrimination against Women (CEDAW) melalui resolusi A/RES/34/180 yang merupakan salah satu usaha untuk mengeliminasi segala tindak diskriminasi dan kekerasan terhadap perempuan.

Salah satu negara yang masih tinggi tingkat pelaksanaan praktek FGM nya di kawasan Afrika Barat adalah Sierra Leone. Budaya yang telah secara turun temurun ini 
menjadi alasan mengapa praktik ini masih tetap dijalankan, padahal pemerintah Sierra Leone telah menandatangani konvensi CEDAW pada 21 September 1998 diikuti dengan peratifikasiannya pada tanggal 11 November 1998 tanpa sayarat apapun (Ningtias, 2017). Konsekuensi dari ratifikasi CEDAW ialah bahwa Negara Peserta (peratifikasi konvensi) memberi komitmen, mengikatkan diri untuk menjamin melalui peraturan perundangundangan, kebijakan, program dan tindakan khusus sementara, mewujudkan kesetaraan dan keadilan antara laki-laki dan perempuan serta terhapusnya segala bentuk diskriminasi terhadap perempuan (Irianto, 2006).

Sierra Leone sebagai salah satu Negara yang telah meratifikasi CEDAW harus mematuhi pasal $2 \mathrm{f}$ dan 5a dimana Negara peserta konvensi harus memasukan kebijakan ini kedalam peraturan perudang-undangan nasionalnya. Konvensi tentang penghapusan segala bentuk diskriminasi terhadap perempuan atau CEDAW ini dapat diartikan sebagai konvensi yang mewajibkan Negara untuk mengambil tindakan terhadap mutilasi genital perempuan atau FGM. Kewajiban setiap Negara yang menandatangani dan meratifikasinya sudah ditulis dalam pasal-pasal yang dibuat oleh konvensi ini, salah satunya yang berkaitan hubungannya dengan FGM adalah pasal 2 dan pasal 5 yang berbunyi (Nations, 1979) :

Pasal 2: "Negara-negara Pihak mengutuk diskriminasi terhadap perempuan dalam segala bentuknya, setuju untuk mengejar dengan segala cara yang sesuai dan tanpa penundaan kebijakan penghapusan diskriminasi terhadap perempuan".

Pasal 5: "Untuk memodifikasi pola-pola perilaku sosial dan budaya laki-laki dan perempuan, dengan maksud untuk mencapai penghapusan prasangka dan adat dan semua praktik lain yang didasarkan pada gagasan inferioritas atau keunggulan salah satu dari jenis kelamin atau pada peran stereotip untuk pria dan wanita".

Sierra Leone juga telah meratifikasi Maputo Protocol pada tahun 2015, piagam hakhak perempuan Afrika, yang menyerukan penghapusan praktik-praktik berbahaya termasuk FGM, tetapi negara itu belum sepenuhnya menghapus praktik tersebut. Maputo Protocol adalah protokol yang menjamin hak-hak komprehensif untuk perempuan yang diadopsi oleh African Union pada 11 Juli 2003 di Maputo (Union, 2016). Menyusul pengadopsiannya, Negara-negara anggota African Union dalam deklarasi tentang Kesetaraan Gender di Afrika melakukan penandatanganan dan meratifikasi Maputo Protocol pada akhir 2004.

WHO Sebagai Inisiator Pada tahun 2018, WHO meluncurkan buku pedoman tentang FGM untuk meningkatkan pengetahuan, sikap dan keterampilan penyedia layanan kesehatan dalam mencegah dan mengelola FGM.

WHO bersama NGOs sedang bekerja dengan Dewan Sowei untuk memastikan bahwa mereka mengikuti larangan memotong genital anak perempuan dan perempuan di bawah 18 tahun. Di tingkat lokal, intervensi masyarakat terhadap FGM dalam banyak kasus lebih berhasil daripada upaya Pemerintah Federal. Para pemimpin di seluruh Sierra Leone telah mengesahkan peraturan daerah yang berkaitan dengan FGM seperti CEDAW dan Maputo Protocol melalui African Union.

Fatmata Turay yang berumur 19 tahun meninggal setelah menjalani praktik FGM yang diyakini sebagai bagian dari kepercayaan masyarakat Bondo. Tiga anggota masyarakat Bondo dan seorang perawat telah ditangkap akibat kejadian ini. Kematian Fatmata Turay juga memacu juru kampanye anti-FGM untuk melarang bahkan menghapus praktik FGM di seluruh Afrika Barat termasuk Sierra Leone (This is Africa, 2016).

Kelompok-kelompok hak asasi yang melakukan kampanye anti-FGM mendesak Sierra Leone untuk melakukan penyelidikan menyeluruh terhadap kematian korban praktik FGM tersebut. Praktek ini masih tersebar luas dan diam-diam dipraktikkan di beberapa 
bagian negara. Kelompok-kelompok hak asasi yang berkampanye melawan FGM, termasuk FORWARD (Foundation for Women's Health Research and Development) adalah yayasan penelitian dan pengembangan kesehatan wanita yang telah beroperasi sejak 1993 di Inggris. Tujuan organisasi ini adalah untuk mempromosikan tentang praktik kesehatan kepada para perempuan di Afrika dan anak-anak internasional. Dalam hal ini FORWARD bekerja dengan Gerakan Pemberdayaan Girl2Girl di Sierra Leone telah menyerukan Pengabaian total FGM sebagai bagian dari upacara Bondo. WHO memiliki tanggung jawab khusus dalam pengembangan materi pelatihan, termasuk persiapan pedoman untuk melengkapi programnnya yaitu mencari pekerja dengan pengetahuan, keterampilan, dan sikap yang sesuai untuk mencegah dan mengeliminasi FGM serta mengelola komplikasi kesehatan yang dihasilkan dari praktik tersebut. WHO akan menggunakan hubungan resminya dengan organisasi internasional untuk membangun kegiatan pelatihan yang ada dan mengembangkan materi pendidikan untuk para profesional.

Respon Masyarakat dan Pemerintah Sierra Leone Ada banyak organisasi non-pemerintah internasional dan nasional, termasuk kemitraan seperti Forum against Harmful Practices (FAHP) dan National Movement for Emancipation and Progress (NaMEP), yang bekerja di tingkat akar rumput di Sierra Leone untuk memobilisasi masyarakat untuk mengakhiri FGM. Beberapa perubahan positif telah diamati dalam hal peningkatan kesadaran dan dialog di sekitar subjek. Namun, upaya-upaya ini masih menghadapi tantangan besar dan tidak didukung sepenuhnya karena tidak adanya kebijakan dan legislasi nasional yang berkelanjutan dalam menangani iau FGM di Sierra Leone.

Tantangan yang dilaporkan termasuk perlawanan berkelanjutan para Soweis terhadap tekanan internasional untuk mengakhiri praktik ini, yang mereka rasakan mengancam masyarakat Bondo tradisional. Banyak pemimpin tradisional juga tetap enggan untuk secara terbuka mendukung pengabaian FGM karena mereka bersama para soweis berharap untuk mempertahankan status mereka di masyarakat serta mendapatkan secara finansial dari biaya inisiasi yang dibayarkan oleh keluarga setiap kali seorang gadis melaksanakan FGM. Tekanan masyarakat dan menyesuaikan diri dengan tradisi tetap tertanam kuat dan dikatakan bahwa ini bukan masalah perempuan yang memberikan persetujuan untuk dipotong, sebaliknya mereka tidak memiliki pilihan dan menghadapi stigmatisasi dari masyarakat jika mereka tidak melakukan praktik FGM (28TOOMANY, 2018).

Mereka yang tidak menjalankan praktik tradisional FGM akan dituduh najis, tidak bermoral dan bahkan berpenyakit. Para Sowei menganggap jika perempuan belum melakukan FGM maka masyarakat disekitarnya tidak akan berbicara dengan mereka (para perempuan yang belum melaksanakan FGM) serta akan diejek di jalanan. Tanpa kebijakan dan undang-undang untuk melindungi perempuan dan anak perempuan yang belum melaksanakan FGM dari bahasa dan perilaku yang kejam seperti itu, tekanan masyarakat untuk melaksanakan praktik FGM akan terus menjadi kuat seperti sebelumnya (28TOOMANY, 2018).

FGM dan Hukum Sierra Leone Sierra Leone saat ini tidak memiliki hukum nasional yang secara eksplisit melarang praktik FGM. Upaya-upaya sebelumnya untuk mengkriminalkannya belum terwujud. Perempuan dan anak perempuan yang belum pernah melaksanakan FGM dilarang untuk mengambil bagian dalam fungsi komunitas tertentu. Praktik ini sebagian besar dilakukan oleh penyunat tradisional (soweis) yang menghasilkan banyak kekuasaan dan kontrol atas fungsi sosial dan politik negara. Karena kurangnya itikad politik, kegagalan Negara untuk langsung mengutuk FGM dan komentar dari berbagai pemimpin politik yang membenarkan praktik ini, membuat pelanggaran hak asasi manusia ini terus berlanjut.

Beberapa Organisasi Internasional terkait isu ini meminta pemerintah Sierra 
Leone untuk secara permanen melarang FGM dengan memberlakukan dan menegakkan hukum anti FGM yang komprehensif. Selain itu pemerintah Sierra Leone juga harus mendukung penjangkauan pendidikan untuk komunitas yang relevan serta kepala daerah tentang bahaya FGM, melindungi wanita dan gadis yang tidak menjalankan praktik FGM dari intimidasi dan pelecehan. Tindakan-tindakan ini akan memastikan bahwa Sierra Leone menghormati tugas nasional, regional dan internasionalnya untuk melindungi hak-hak perempuan dan anak perempuan (EqualityNow, 2020). Menimbang bahwa tidak ada undang-undang di Sierra Leone yang mengkriminalkan FGM secara eksplisit, belum ada penuntutan yang terdokumentasi mengenai FGM di Sierra Leone. Selain itu, karena ketidaksetaraan gender yang ada di Sierra Leone, undang-undang yang dimaksudkan untuk melindungi dan menegakkan hak-hak perempuan dan anak perempuan tidak dilaksanakan sebagaimana mestinya (EqualityNow, 2020).

\section{SIMPULAN}

Female Genital Mutilation dengan tipe apapun merupakan salah satu bentuk pelanggaran HAM, khususnya HAP. Beragam regulasi internasional dan nasional mengenai HAM telah dilanggar oleh adanya praktik FGM tersebut dari mulai sebelum dan sesudah prosedur, dampak dari praktinya hingga sarana dan prasarana yang digunakan dalam praktik FGM. Praktik FGM juga merupakan sebuah bentuk kekerasan berbasis gender karena berakar pada tingkat ketidaksetaraan gender dan ketidakseimbangan kekuasaan antara pria dan wanita yang menghambat perempuan untuk mendapatkan penikmatan yang sama atas hak asasi manusia mereka. Kepercayaan akan masyarakata Sierra Leone terhadap praktik tradisional FGM menjadikan pemerintah Sierra Leone tidak memasukan larangan atas praktik FGM kedalam konstitusi nasionalnya.

WHO sebagai organisasi internasional telah melakukan tugasnya baik sebagai Fasilitator, Determinator maupun Inisiator. Hal ini dapat dilihat dari peran WHO melalui CEDAW, Maputo Protocol, serta kerjasama internasional bersama organisasi internasional dan para aktivis dalam penghapusan FGM di Sierra Leone. Dalam 4 peran WHO, hanya 3 perannya yang dapat di implementasikan pada isu FGM di Sierra Leone, karena sesuai dengan pengertiannya WHO sebagai Mediator berperan sebagai penegah antara 2 belah pihak dalam menyelesaikan suatu isu/masalah internasional dam peran WHO sebagai Mediator dirasa kurang tepat dalam mengangani isu Female Genital Mutilation di Sierra Leone. WHO sebagai organisasi internasional dalam menangani isu FGM di Sierra Leone tidak bisa mengintervensi konstitusi negara tersebut. Sierra Leone sebagai negara yang telah meratifikasi dan menandatangani konvensi CEDAW dan Protokol Maputo tidak dapat memasukan larangan penghapusan praktik FGM dalam undang-undangnya karena adanya kepentingan politik di negara tersebut. 
28TOOMANY. (2018, September). Sierra Leone: The Law and FGM. Diambil kembali dari 28TOOMANY:

https://www.28toomany.org/static/media/uploads/Law\%20Reports/sierra_leone_law_ report_v1_(september_2018).pdf

Anadia, F. P. (2017). Implementasi Kebijakan WHO (World Helath Organization) di Benin. Universitas Pasundan.

Aprinanda. (2016). Peran UNCHR Dalam Menangani Pengungsi Suriah Di Lebanon. Scholar Universitas Andalas, 15-17.

Creswell, J. W. (2010). Research Design Pendekatan Kualitatif, Kuantitatif, dan Mixed. Yogyakarta: Pustaka Pelajar.

EqualityNow. (2020, June 29). Learn More: FGM in Sierra Leone. Diambil kembali dari A Just World For Women and Girls: https://www.equalitynow.org/learn_more_fgm_in_sierra_leone

EqualityNow. (2020, June 20). Sierra Leone: Enact a Comprehensive Anti-FGM Law. Diambil kembali dari https://www.equalitynow.org/sierra_leone_enact_a_comprehensive_anti_fgm_law\#: :text=Sierra\%20Leone\%20does\%20not\%20presently,part\%20in\%20certain\%20com munity\%20functions.

Irianto, S. (2006). Perempuan dan Hukum: Menuju Hukum yang Berperspektif Kesetaraan dan Keadilan. Jakarta: Yayasan Obor Indonesia.

Kusuma, A. J., \& Sitorus, F. E. (2019). Strategi Diplomasi Kemanusiaan Pemerintah Indonesia Dalam Kasus Krisis Kemanusiaan Yang Dialami Etnis Rohingya Di Myanmar Tahun 2017. MANDALA, 151-168.

Nations, U. (1979, December 18). Convention on the Elimination of All Forms of Discrimination against Women New York, 18 December 1979. Diambil kembali dari United Nations: https://www.ohchr.org/EN/ProfessionalInterest/Pages/CEDAW.aspx

Nations, U. (1995, August). Harmful Traditional Practices Affecting The Health of Women And Children. Diambil kembali dari United Nations Office of The High Commissioner for Human Rights: https://www.un.org/ruleoflaw/blog/document/harmful-traditional-practices-affectingthe-health-of-women-and-children-fact-sheet-no-23/

Ningtias, D. A. (2017). Implementasi Convention on the Elemination of All Form of Discrimination Against Women (CEDAW) Dalam Penghapusan Praktik Female Genital Mutilation (FGM) Di Sierra Leone Tahun 2008-2013. Repository Universitas Riau JOM Fisip, 3. 
Refworld. (2020, July 15). Fact Sheet No. 23, Harmful Traditional Practices Affecting the Health of Women and Children. Diambil kembali dari Refworld: https://www.refworld.org/docid/479477410.html

Saputri, R. A., \& Tumangger, J. (2019). HULU-HILIR PENANGGULANGAN STUNTING DI INDONESIA. JPI: Jurnal of Political Issues, 1-9. https://doi.org/10.33019/jpi.v1i1.2

Satrio, A. (2008). Peran PBB Sebagai Organisasi Internasional Dalam Penyelesaian Perang Internal Di Sierra Leone. FISIP UI, 13.

This is Africa. (2016, August 19). Diambil kembali dari This is Africa: https://thisisafrica.me/politics-and-society/sierra-leone-19-year-old-school-girl-diesbotched-fgm-operation/

UNFPA. (2017, February 6). Statement by the United Nations in Sierra Leone on the International Day of Zero Tolerance for Female Genital Mutilation. Diambil kembali dari UNFPA: https://sierraleone.unfpa.org/en/news/statement-united-nations-sierraleone-international-day-zero-tolerance-female-genital

UNICEF, U. C. (2016). Statistical Profile on Female Genital Mutilation/cutting: Sierra Leone. Diambil kembali dari Refworld.org: https://www.refworld.org/docid/5a17d3f14.html

Union, A. (2016, April 15). Status of Implementation of the Protocol to the African Charter on Human and People's Rights on the Rights of Women in Africa. Diambil kembali dari Relief Web International: https://reliefweb.int/report/world/statusimplementation-protocol-african-charter-human-and-people-s-rights-rightswomen\#: :text=As\%20of\%20October $\% 202015 \% 20$ however,ratified $\% 20$ on $\% 2030 \%$ 20 October\%202015.

WHO. (2020). Female genital mutilation. Diambil kembali dari who.int: https://www.who.int/news-room/fact-sheets/detail/female-genital-mutilation 


\title{
Perbandingan Tata Kelola Penanganan Pandemi Covid 19 di Indonesia dan India
}

\author{
Nisa Khoerunisa ${ }^{1}$ dan Faisal Fadilla Noorikhsan ${ }^{1^{*}}$ \\ ${ }^{1}$ Jurusan Ilmu Politik, Universitas Siliwangi, 46115, Tasikmalaya-Indonesia
}

\begin{tabular}{l}
\hline \hline Info Artikel \\
\hline Dikirim: Okt 19, 2020 \\
Diterima: Jan 27, 2021 \\
Dipublikasi: Jan 31, 2021 \\
\hline
\end{tabular}

Kata Kunci:

Covid 19;

Kebijakan;

Lockdown;

PSBB;

Koresponden:

Faisal Fadilla Noorikhsan

Jurusan Ilmu Politik

Universitas Siliwangi

Email:

faisal.fadilla@unsil.ac.id

\section{Sitasi Cantuman:}

Khoerunisa, N. \& Noorikhsan, F. F. (2021). Perbandingan Tata Kelola Penanganan Pandemi Covid 19 di Indonesia dan India. Journal of Political Issues. 2(2); 89-101. https://doi.org/10.33019/jpi.v2i 2.36

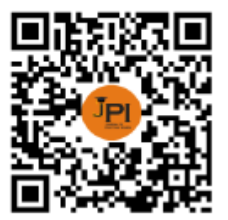

DOI:

https://doi.org/10.33019/jpi.v2i 2.36

ABSTRAK

Abstract This paper tries to compare the governance of handling the Coronavirus Diseases (Covid 19) pandemic in Indonesia and India. Although it had implemented a total lockdown until September the number of positive cases of COVID-19 in India reached more than 4.7 million with a death toll of more than 78 thousand people. Meanwhile, Indonesia has never recorded a total lockdown. The result is no better than India. Throughout September, seven times the record positive addition of Covid 19 broke. We try to do the best government policy analysis among the worst. This paper is made from qualitative research, namely research aimed at generating knowledge in a coherent way. Using the literature method, collecting as much information from print and electronic media related to COVID 19 in Indonesia and India, we analyzed the policies of the governments of the two countries. This paper recommends a thorough evaluation of the Indonesian government's policy in handling covid 19. Indonesia now tops the statistics on the number of deaths due to COVID-19 in Southeast Asia.

Abstrak Tulisan ini mencoba membandingkan tata kelola penanganan pandemi Coronavirus Diseases (Covid 19) di Indonesia dan India. Meskipun sempat menerapkan lockdown total sampai bulan September jumlah kasus positif COVID-19 di India tembus lebih dari 4,7 juta dengan angka kematian lebih dari 78 ribu jiwa. Sementara itu, Indonesia tak pernah tercatat melakukan lockdown total. Hasilnya tidak lebih baik dari India. Sepanjang bulan September tercatat tujuh kali rekor penambahan positif Covid 19 pecah. Kami coba melakukan analisis kebijakan pemerintah terbaik di antara yang terburuk. Tulisan ini dibuat dari penelitian kualitatif yakni penelitian yang ditujukan untuk menghasilkan pengetahuan dengan cara koheren. Dengan menggunakan metode kepustakaan, mengumpulkan sebanyak mungkin informasi dari media cetak dan elektronik terkait covid 19 di Indonesia dan India, kami menganalisis kebijakan pemerintah kedua negara tersebut. Tulisan ini merekomendasikan evaluasi menyeluruh terhadap kebijakan pemerintah Indonesia dalam penanganan covid 19. Pasalnya, kini Indonesia menduduki posisi teratas statistik jumlah kematian akibat COVID-19 di Asia Tenggara.

\section{Tentang:}

Nisa Khoerunisa, menyelesaikan Pendidikan S2 pada jurusan Magister Ilmu politik Universitas Padjajaran dan sekarang ini menjadi dosen tetap pada jurusan Ilmu Politik Universitas Siliwangi Tasikmalaya.

Faisal Fadilla Noorikhsan, menyelesaikan pendidikan S2 pada jurusan Magister Ilmu Politik Universitas Diponegoro Semarang tahun 2016. Saat ini menjadi dosen tetap pada jurusan Ilmu Politik Universitas Siliwangi Tasikmalaya

Lisensi:

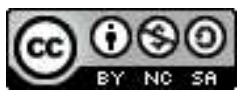

Attribution-NonCommercialShareAlike 4.0 International (CC- BY-NC-SA 4.0)

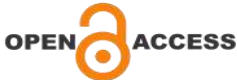




\section{PENDAHULUAN}

Pandemi Covid 19 merupakan salah satu pandemi dalam sejarah kontemporer. Di tengah globalisasi yang makin dalam dan masifnya perkembangan teknologi informasi, pandemi ini menghadirkan tentangan yang lebih besar dan kompleks. Kajian yang muncul sesaat setelah Covid 19 dinyatakan muncul adalah dampaknya terhadap ekonomi politik global dan domestik. Jika pandemi-pendemi sebelumnya menular melalui perantara binatang atau interaksi khusus antar manusia, Covid 19 memiliki karakter yang menular langsung antarmanusia (Shereen dkk., 2020).

Pemerintah dibanyak negara dihadapkan pada situasi membingungkan saat wabah covid 19 muncul. Mereka dipaksa mengambil langkah-langkah strategis guna menangani dan merespon keadaan pandemi. Masing-masing negara menunjukkan kesiapan yang berbedabeda. Pandemi Covid 19 juga telah menunjukan baik buruknya tata kelola dan kebijakan pemerintah suatu negara. Pada awalnya pemerintah Indonesia menunjukkan kegagapan dan terjebak dalam penyangkalan atas tingkat urgensi maupun dampak covid 19 sebelum akhirnya mengambil langkah-langkah yang dibutuhkan untuk menangani pandemi secara lebih sistematis. (Mas'udi \& Winarti 2020)

Sementara itu, India dengan populasi penduduk lebih dari 1,3 milyar mencatatkan angka kasus positif COVID-19 yang semakin meningkat. Pada bulan Juli (07/2020), satu bulan setelah lockdown dilonggarkan, India menjadi negara ketiga dengan kasus covid-19 terbanyak di dunia setelah Amerika Serikat dan Brasil. Kasus melaju pesat dengan penambahan lebih dari 20.000 kasus terkonfimasi setiap harinya. (BBC NEWS Indonesia, 2020). Terlepas dari kemajuan teknologi serta pelayanan kesehatan, pandemi membuat pemerintah mengambil kebijakan yang cenderung bersifat trial and error, yang berdampak pada keberlangsungan kehidupan warga negaranya.

Berbagai pendekatan menghadapi pandemi Covid 19 tidak terlepas dari pengaruh sistem politik, kultur dan gaya pemimpin negara masing-masing. Misalnya saja Korea Selatan yang memilih menggunakan tracing seluas mungkin, India dengan memilih lockdown, atau penggunaan PSBB yang dilakukan oleh Indonesia. Di Jepang, sekolah dan perguruan tinggi ditutup mulai pertengahan maret 2020. Penutupan tersebut membuat sekitar 13 juta murid dan mahasiswa di seluruh Jepang harus tinggal di rumah masing-masing, menghentikan semua program perkuliahan tatap muka, dan program-program magang di perusahaan (Davidson, Kuo dan McCurry, 2020). Pemerintah Vietnam, Laos, India, Srilanka, dan Malaysia memutuskan menutup semua kegiatan pendidikan sejak awal maret 2020

Pandemi juga menimbulkan issu baru terkait keberlangsungan sistem politik mana yang paling relevan dan berhasil menangani krisis demi peradaban hidup manusia. Ilmuan politik kembali menggulirkan perdebatan mengenai tipe rezim, demokratis vs otoriter, dan juga pilihan kebijakan pemerintah mana yang efektif, lockdown vs bukan lockdown. Baik Indonesia maupun India adalah negara di benua Asia yang masuk dalam kajian Global Democracy Ranking dengan posisi yang tidak jauh berbeda. Menurut Global Democracy, pada tahun 2015 Indonesia menempati peringkat ke 68, sedangkan India jauh lebih baik 3 tingkat yakni berada diurutan 65 (Global Democracy Ranking, 2015). Indonesia dan India dikategorikan sebagai developmental democratic state atau negara demokrasi yang sedang mengalami transisi. Keduanya memiliki persamaaan secara demografis dan historis yang membuat civil society dan proses demokratisasi diantara keduanya memiliki persamaan. Salah satunya adalah bermunculannya fenomena uncivil society (atau civil society yang sakit). Hal ini ditandai misalnya dengan bermunculan kelompok dengan membawa politik identitas tertentu dengan menggunakan kampanye kekerasan dalam gerakannya. (Muradi, 2016).

Tulisan ini mencoba membandingkan sejauh mana efektivitas tata kelola pandemi Covid 19 didua negara, yaitu Indonesia dan India. Sebagai negara yang sama-sama terkena dampak Covid-19, India memberlakukan lockdown total sebagai pilihan kebijakan yang 
diambil oleh pemerintah, sedangkan Indonesia menerapkan Pembatasan Sosial Berskala Besar (PSBB) selama tiga bulan, mulai dari pertengahan bulan Maret sampai Juni 2020. Menurut laporan Knowledge Group yang dimuat di laman Forbes, Indonesia masuk kategori 20 negara dengan tingkat safety serangan virus paling rendah, dengan risiko-risiko penularan paling tinggi. Dalam hal safety yang diukur dari aspek kebijakan berkaitan dengan quarantine efficiency, government management efficiency, monitoring and detection, dan emergency treatment readiness, Indonesia berada dalam lima negara dengan tingkat keamanan terbawah, bersama India, Srilanka, Myanmar, Kamboja, dan Laos (Colangelo, 2020)

Sebagai negara dengan populasi terbanyak didunia, baik India maupun Indonesia berhadapan dengan persoalan besar saat WHO menetapkan status Coronavirus Disease (covid-19) sebagai pandemi. Penyakit yang sudah menginfeksi lebih dari 110 negara ini disikapi dengan respon yang berbeda. Beragam pilihan sikap tersebut dinilai berhasil jika mampu menahan laju penyebaran dan rendahnya angka kematian yang disebabkan oleh covid-19. Kontrol pemerintah dan kebijakan yang responsif tersebut bukan hanya menyoal pengendalian angka fatalitas namun juga keberlangsungan hidup warganya secara umum. Dengan melihat pengamanan India yang memilih retriksi total (lockdown), lalu Indonesia dengan pembatasan sosial berskala besar (PSBB), tulisan ini bermaksud melihat efektivitas pilihan yang diambil oleh keduanya. Mekanisme pengambilan keputusan yang dilakukan oleh para pemangku kebijakan paling berperan dalam menekan laju penyebaran covid. Tujuan utama tulisan ini adalah sebagai studi awal respon negara terhadap penanganan Covid-19 dari perspektif efektivitas kebijakan. Artikel ini selanjutnya akan memetakan pendekatan yang dilakukan oleh Indonesia dan India untuk mengelola pandemi serta membandingkan efektivitas keberhasilan diantara kebijakan lockdown dengan PSBB. Berikutnya rumusan masalah yang akan dijawab adalah "Bagaimana Indonesia dan India mengelola krisis pandemi? Sejauh apa keberhasilan kebijakan lockdown di India dan PSBB di Indonesia mengatasi krisis pandemi?"

\section{METODE PENELITIAN}

Rancang penelitian yang digunakan oeh penulis adalah studi perbandingan (comparative study or casual comparative study). Jenis tulisan ini mengacu pada bentuk penelitian deskriptif yang membandingkan dua atau lebih dari situasi, kejadian, kegiatan, program dll, yang sejenis atau sama. (Syaodih, 2007) Tulisan dalam penelitian menggunakan metode kepustakaan. Adapun metode ini digunakan karena secara bibliografis berguna untuk menyusun kembali informasi empiris yang menjadi tema penulisan. Selain karena fungsinya sebagai membantu secara bibliografis, metode ini tepat digunakan untuk sebagai alternatif untuk mensiasati keterbatasan penulis untuk terjun langsung ke lapangan.

Teknik pengumpulan data dalam studi ini adalah dengan menggunakan metode studi literatur. Berbagai data sekunder di antaranya: artikel-artikel media massa, cetak maupun online terkait pandemi Covid-19 dengan berfokus mengkaji di dua negara, yaitu Indonesia dan India. Penulis memilih kedua Negara tersebut karena masing-masing dapat merepresentasikan kebijakan penanganan pandemi yang berbeda. Sumber-sumber lain dalam bentuk rekaman vidio menjadi data penunjang penelitian untuk memahami lebih jauh pandemi Covid-19, respon negara terdampak, dan dampaknya terhadap sosial-poitik. Datadata yang ada penulis olah dengan menggunakan pendekatan critical reading.

\section{HASIL PENELITIAN \\ Pandemi Yang Mengguncang Dunia}

Bermula dari kota Wuhan, China, virus varian baru yang kemudian diidentifikasi sebagai SARS Cov-2 menjadi bencana yang mewabah di seluruh negara di dunia. Respon negara dalam menghadapi pandemi Covid-19 beragam. Suatu negara dikatakan tanggap dalam 
penanganan pandemi apabila terdapat kepemimpinan yang kuat yang direspon solid oleh rakyatnya. Kesiapsiagaan suatu negara juga ditentukan dari seberapa mampu menekan laju penyebaran, tingkat fatalitas, kemampuan menangani pasien terinfeksi, serta dilihat dari kapasitas mobilisasi dan mengelola sumber daya secara tepat untuk menangani krisis beserta dampaknya. Kebijakan yang bersifat komprehensif juga mencakup keseluruhan siklus situasi krisis, mulai tanggap darurat, penanganan dampak sosial-ekonomi. Untuk menanggulangi perkembangan virus tersebut, berbagai cara ditempuh oleh negara agar dapat menjamin keberlangsungan hidup warga negaranya.

Penanganan Covid-19 dan dampaknya, membutuhkan kapasitas sumber daya yang sangat besar. Di beberapa negara bisa disaksikan pengerahan sumber daya yang luar biasa besar, baik untuk menangani wabah maupun untuk menyelamatkan ekonomi dan kehidupan sehari-hari masyarakat dengan berbagai bentuk subsidi ekonomi dan jaring pengaman sosial. Gerak cepat yang dilakukan oleh tiap negara dalam merespon covid-19 sangat menentukan bukan hanya laju angka perkembangan covid-19, tetapi juga gerak roda perekonomian warga negaranya. Sebagaimana halnya dengan negara-negara lain yang terdampak, Indonesia melakukan berbagai upaya agar penyebaran virus bisa ditekan semaksimal mungkin. Luasnya wilayah Indonesia, dengan jumlah populasi yang tidak sedikit membuat pemerintah Indonesia secara bertahap memberlakukan pembatasan aktivitas serta penutupan akses wilayah. Pilihan bersebrangan dilakukan oleh India yang secara mendadak melakukan retriksi total.

Indonesia adalah negara dengan populasi terbesar di Asia Tenggara. Begitu juga dengan India, sebagai peringkat pertama terpadat di Asia Selatan. Kondisi tersebut menimbulkan kekhawatiran dari pihak WHO yang menilai jika kedua negara tersebut dapat menjadi episenter baru. Senior Advisor on gender and Youth to the WHO, Diah Saminarsih mengatakan jika kedua negara ini tidak dapat mengontrol epidemi, maka Kawasan Asia Tenggara menjadi episenter di dunia, menggeser Amerika dan Eropa (Nursastri, 2020). Hal tersebut menjadi tantangan besar bagi pemerintah masing-masing negara dalam memformulasikan kebijakan yang dibuat.

Selain itu, pengelolaan pandemi Covid 19 menghadapi tantangan karena mobilitas manusia masa kini yang sangat tinggi. Covid 19 juga berkembang ketika populisme (kepemimpinan politik nasionalis dan sikap anti-science) semakin meluas dalam politik domestik banyak negara. Situasi dimana seharusnya pemerintah mengambil kebijakan rasional yang sifatnya jangka panjang, tergantikan oleh langkah politik dan kebijakan berorientasi popularitas jangka pendek dan berorientasi kepentingan untuk memperkokoh kekuasaan (Kluth, 2020). Karakter pandemi ini dijadikan komoditas politik personal atau kelompok, dengan mengorbankan esensi penanganan krisis, yaitu kemanusiaan.

\section{Semrawut Lockdown India Atasi Krisis Pandemi}

India adalah negara besar dengan populasi penduduk yang padat dan mengalami kasus Covid-19 tercatat sebanyak 1.116.597 hingga 19 Juli 2020 (HT Correspondent, 2020). Kasus Covid-19 pertama kali didokumentasikan pada tanggal 30 Januari 2020, yang mana adalah warga India yang dievakuasi dari China. (Laxminarayan, dkk, 2020) Dalam menangani covid-19, India menggunakan langkah-langkah pro-aktif yang terdiri dari pengujian agresif yang dilakukan oleh pemerintah pusat yang bekerjasama dengan negara bagian wilayahnya. Jika Indonesia tidak menggunakan langkah lockdown, negara dengan mayoritas beragama Hindu itu berani mengambil langkah untuk mengunci negaranya dalam beberapa tahapan. Negara yang terletak di Kawasan Asia Selatan ini menerapkan kebijakan lockdown, sejak 25 Maret 2020 untuk diberlakukan selama tiga pekan. Skenario tersebut digunakan oleh India untuk melacak orang yang terinfeksi yang akan terlihat gejalanya selama 14 hari, dan satu minggu kemudian dicadangkan untuk mengamati situasi infeksi, kematian dan tingkat pemulihan (Paital, Das, and Parida, 2020) 
Lockdown sendiri membawa konsekuensi bagi diberhentikannya semua aktivitas, baik itu bisnis maupun transportasi publik. Akibatnya, eksodus besar-besaran terjadi di kota besar. Belum seminggu sejak lockdown ditetapkan, India mengalami banyak persoalan. Berbagai persoalan muncul ke permukaan dan berujung krisis kemanusiaan pasca pengumuman Lockdown diberlakukan. Meskipun Pemerintah India mengumumkan bantuan stumulus ekonomi sebesar 260 Milyar kepada rakyatnya, namun dikarenakan tahapan skemanya belum jelas, jutaan pekerja informal dan pekerja migrant kehilangan pekerjaannya. 10 juta pekerja India kesulitan bagaimana mengakses makanan (International Growth Centre, 2020). Penguncian dengan minimalisir persiapan tersebut, selain mengakibatkan jutaan pekerja menganggur, pada akhirnya berdampak pada peningkatan laporan serangan rasis terhadap migran dari India Timur, termasuk dengan kekerasan fisik yang ditangkap dan dibagikan ke media social. (Kikon, 2020)

Kerusuhan terjadi akibat ratusan ribu orang memaksa untuk pulang kampung, kekerasan yang dilakukan oleh aparat marak terjadi, kasus kelaparan pun merajalela. Bahkan, tagar \#ModiMadeDisater sempat menjadi trending topic di twitter. (Adam, 2020). Begitu juga saat kemudian keputusan untuk memperpanjang lockdown dilakukan oleh India hingga 3 Mei 2020. Lockdown yang semula direncanakan berakhir pada 14 April harus mengalami perpanjangan karena Narendra Modi berkeyakinan jika penguncian dan distancing social merupakan cara yang efektif untuk melindungi warganya yang berjumlah 1,3 Miliar.

Pemerintah India lantas memperpanjang lockdown hingga 30 Juni 2020, dengan hanya mengizinkan pembukaan kegiatan ritel, rekreasi dan perbelanjaan secara bertahap (Saha, Barman, and Chouhan, 2020). Pemerintah memberikan keringanan bagi para petani dan pekerja harian dalam pemberlakuan aturan tersebut. Pemerintah India menilai pengorbanan kerugian ekonomi yang harus ditanggung akibat dari lockdown tidak lebih berarti daripada mempertahankan kehidupan warganya. Meskipun banyak menimbulkan persoalan kemanusiaan dan mendapatkan kritikan, lockdown yang diterapkan India selama 45 hari membuahkan hasil yang positif dan diklaim memainkan peranan besar dalam menekan angka penyebaran penyakit. (Bhattacharjee, Kumar, and Patel, 2020). Lockdown yang tepat waktu membuat volume yang terinfeksi covid-19 di India lebih sedikit dibandingkan negara besar lainnya. (Pai, Bhaskar, and Rawoot, 2020) Tindakan penguncian tersebut mendapatkan apresiasi dari WHO karena India sebagai negara terpadat kedua didunia menunjukkan tingkat infeksi dan kematian yang rendah dibandingkan negara lain. Masing-masing yaitu 9.152 dan 306 per 1,3 miliar populasi per/13 April 2020 (Paital, Das, and Parida, 2020). Selain menekan laju penyebaran covid-19, lockdown membawa dampak signifikan bagi kondisi lingkungan dan udara disana. India mengalami proses peremajaan yang ditandai oleh pengurangan polutan yang cukup berbahaya dan berakibat fatal bagi kesehatan manusia (Lal \& Pawar, 2011)

Guna menanggulangi dampak pandemi Covid 19, India menggelontorkan anggaran sebesar US\$2,1 milliar untuk melengkapi fasilitas kesehatan. Dari anggaran tersebut, Departemen Sains dan Tekhnologi Pemerintahan India telah mengajukan skema untuk mempromosikan penelitian dan penemuan di lembaga-lembaga penelitian yang bekerja dalam pengendalian wabah ketika sedang dilakukan lockdown. CSIR atau Dewan Riset Industri India India juga mengalami krisis infodemik dimana hoax Covid-19. India adalah pengguna internet dan media sosial kedua setalah China. Sebagai negara dengan populasi rakyat terbesar kedua di dunia, India menggabungkan berbagai pendekatan dalam mengatasi laju covid-19. Sekalipun menimbulkan efek kemanusiaan, lockdown dianggap membawa dampak signifikan bagi penekanan angka laju Covid-19. Gaya kepemimpjnan dibawah Perdana Menteri Narendra Modi yang tergas menyerukan lockdown dengan keseriusan sejak awal pandemik berkembang. Kesigapan otoritas kesehatan di India melalui proses pelacakan dan pengujian dilakukan guna menekan angka kematian. 
Langkah-langkah strategis yang dilakukan oleh pemerintahan India tersebut tidak bertahan lama. Proses penguncian tersebut selain menimbulkan dampak sosial, berdampak juga pada perputaran roda ekonomi sehingga India mulai melonggarkan kebijakan lockdown. Jika saat penguncian dilakukan selama bulan Maret-Mei kasus terkonsentrasi di kota-kota besar, pelonggaran lockdown berdampak pada mobilisasi penduduk India dari kota ke daerah pedesaan, yang berakibat pada penyebaran kasus Covid-19 di pedesaan. Pilihan kebijakaan untuk melonggarkan lockdown membuat kasus infeksi melonjak kembali dengan tajam. Memasuki bulan Agustus, kasus meningkat dan berkembang dengan cepat sehingga mencapai 75.000 kasus infeksi setiap harinya. Tercatat hingga pekan keempat Agustus (08/2002), India menjadi negara ketiga dengan catatan kematian tertinggi setelah Amerika Serikat dan Brazil dengan angka kematian mencapai 60.000 dan kasus terkonfirmasi sebanyak 3 juta kasus. (Gettleman, \& Yasir, 2020)

\section{Kegagapan Indonesia Hadapi Krisis Pandemi}

Ketika kasus pertama covid-19 terkonfirmasi di Indonesia pada tanggal 2 Maret 2020, secara global kasus terkonfirmasi sudah mencapai 88.948 kasus. Kasus pertama terkonfirmasinya Covid-19 di Indonesia dilaporkan WHO pada "situation report 2", dimana Indonesia tercatat bersama 5 negara lain yaitu Armenia, Czechia, Republik Dominika, Luksemburg, dan Islandia (WHO, 2020). Situasi krisis yang datang tiba-tiba memicu kepanikan semua pihak, baik di level pemerintah pusat maupun pemeirntah daerah serta masyarakat biasa. Dalam kondisi seperti itu pengambil kebijakan dituntut untuk membuat kebijakan yang dapat mereduksi potensi konflik akibat situasi krisis (Ambar \& Mas'udi, 2020)

Seminggu setelah kasus pertama terkonfirmasi dan kasus semakin melonjak, berbagai pihak mulai menggaungkan suara untuk melakukan lockdown (karantina wilayah) seperti yang sudah dicontohkan oleh negara lain seperti Tiongkok. Namun seruan lockdown ini tak membuat pemerintah bergeming. Presiden Joko Widodo memiliki keyakinan bahwa penyebaran Covid 19 bisa dilakukan dengan Physical Distancing. Meskipun pihak IDI menganggap karantina wilayah lebih efektif untuk memutus mata rantai penyebaran covid-19 dibandingkan pemberlakuan PSBB, namun pemberlakuan karantina wilayah tidak diberlakukan oleh Joko Widodo dengan pertimbangan ekonomi, geografis, kultural, dan sosiologis masyarakat Indonesia yang berbeda dengan negara lain yang menerapkan karantina wilayah. Menurut Joko Widodo, karantina wilayah tidak dipilih setelah membandingkan kebijakan tersebut dari negara lainnya yang dinilai tidak menjamin keberhasilan penerapan karantina wilayah tanpa menimbulkan masalah. Menurutnya, tidak ada satu formula yang pasti dalam mengatasi persoalan covid-19 ini. (Najwa Shihab, 2020)

Pemberlakuan kebijakan sosial berskala besar baru ditetapkan oleh Joko Widodo pada akhir Maret sebagai kelanjutan dari pembatasan social distancing dengan menggunakan Peraturan Pemerintah nomor 21 tahun 2020 sebagai dasar peraturan. Kebijakan tersebut diambil karena penambahan kasus yang makin meningkat dari hari ke hari. Juru bicara pemerintah untuk penanganan Covid-19 Achmad Yurianto yang sekaligus menjabat Dirjen Pencegahan dan Pengendalian Penyakit Kemenkes mengatakan jika PSBB dilakukan karena physical distancing yang diabaikan oleh masyarakat. Menurutnya, jika pembatasan sosial tidak mempan, maka akan diberlakukan pembatasan sosial berskala besar. Cara tersebut ditempuh karena diyakini dapat memutus rantai penularan. Ditambahkan olehnya, jaga jarak harus juga dilakukan karena jika hal tersebut gagal dilakukan maka negara akan terancam jebol. (Tempo, 2020)

Indonesia tergolong terlambat merespon situasi krisis. Jika dilihat dari perspektif komunikasi publik, Indonesia sempat melakukan hal gegabah dengan pernyataan-pernyataan simplikatif dari para pejabat publik. Misalnya saja klaim jika Indonesia sebagai satu-satunya negara yang tidak terinfeksi, atau kampanye jamu sebagai penangkal obat (Fakhruroji, dkk, 2020). WHO kemudian memberikan peringatan kepada Indonesia agar segera 
mendeklarasikan darurat nasional Covid-19 melalui surat tertanggal 10 Maret 2020 yang ditujukan kepada Presiden Indonesia, Joko Widodo (Berty, 2020). Dampaknya adalah pemerintah mengeluarkan produk hukum "tahu bulat". Hanya dalam jangka waktu satu bulan, 9 produk hukum terkait penanganan pandemi Covid-19 diterbitkan. Kebijakankebijakan tersebut merupakan respon atas eskalasi masalah ditinjau dari segi kesehatan masyarakat, sosial, administrasi, keuangan, kewenangan dan politik birokrasi pemerintahan.

Untuk menjaga stabilitas keuangan negara akibat krisis pandemi pemerintah Indonesia mengeluarkan Peraturan Pemerintah Pengganti Undang-Undang (Perppu) Nomor 1 tahun 2020 tentang Kebijakan Keuangan Negara dan Stabilitas Sistem Keuangan untuk Penanganan Covid-19 dan dalam rangka menghadapi ancaman yang membahayakan perekonomian nasional dan stabilitas sistem keuangan, tanggal 31 Maret 2020. Perppu ini menjadi landasan hukum bagi penyesuaian anggaran dalam kondisi luar biasa, sekaligus justifikasi penambahan anggaran belanja dan pembiayaan APBN 2020 untuk menangani Covid 19, dengan total tambahan belanja dan pembiayaan APBN tahun 2020 sebesar 405,1 triliun.

Selain itu, Dana sebesar 110 trilyun dialokasikan pemerintah untuk tambahan jaring pengaman social terkait covid-19. Jangkauan program keluarga harapan diperluas dari 9,2 juta penerima menjadi 10 juta penerima dan nilainya ditambah $25 \%$. Peruntukkan kartu sembako yang semula dianggarkan untuk 15,2 juta penerima diperbesar menjadi 20 juta penerima dengan nilai manfaat yang naik dari 150 ribu menjadi 200.000. Kemudian anggaran anggaran kartu prakerja dinaikan dari 10 trilliun menjdi 20 triiliun dengan rincian jumlah penerima. manfaat ditambah dari dua juta orang menjadi 5,6 juta penerima (Kompas, 2020)

Kebijakan Pembatasan Sosial Berskala Besar (PSBB) dilaksanakan setelah terbitnya Peraturan Pemerintah (PP) Nomor 21 tahun 2020, tanggal 31 Maret 2020, tiga minggu setelah kasus pertama diumumkan di Indonesia. PP tersebut mengatur tentang pelaksanaan PSBB dan pemerintah daerah dapat melaksanakannya atas persetujuan Menteri Kesehatan. Dengan jumlah kasus yang telah meningkat dan meluas lintas wilayah kebijakan ini sangat terlambat. Karena PSBB baru dilaksanakan bulan April, dan tidak serentak semua wilayah melaksanakannya.

PSBB di DKI Jakarta sendiri, misalnya, baru diberlakukan pada hari pertengahan April 2020. Kemudian diikuti oleh berbagai kota besar lainnya (Carina, 2020). Meskipun PSBB diberlakukan masyarakat masih diperbolehkan untuk keluar rumah dengan mengikuti mengikuti protokol kesehatan yang telah ditentukan. Penerapan PSBB yang diberlakukan di berbagia daerah tidak serta merta dipatuhi oleh masyarakat. Berbagai pelanggaran masih terjadi dan ditemukan selama penerapan PSBB. Misalnya saja keramaian masih ditemukan di jalan-jalan utama sebagian daerah wilayah DKI Jakarta hingga sepekan sejak PSBB diberlakukan. Pengendara sepeda motor masih banyak yang tidak menggunakan masker dan berboncengan. Begitu juga dengan para pedagang yang menawarkan dagangannya. Tercatat selama penerapan periode pertama penerapan PSBB di Jakarta, Polda Metro jaya mencatat ada 32.300 kendaraan yang melanggar aturan (Kompas, 2020). Jika merunut kronologi awal respon pemerintah terhadap pandemi Covid 19 maka ada empat faktor penyebab kegagalan kebijakan PSBB pemerintah Indonesia.

Pertama, lemahnya respon awal penangangan Covid-19. Hal tersebut bisa dilihat dari respon 'santai' yang ditunjukan oleh pejabat hingga menimbulkan sengkarut koordinasi diantara instansi pusat dan daerah. Krisis komunikasi yang terjadi mengakibatkan penaganan covid-19 di berbagai daerah tidak transparan dan terpadu. Kondisi tersebut terlihat dari berbagai penelitian yang menunjukan dis-trust yang ditunjukkan oleh publik kepada pemerintah. Penelitian yang dilakukan oleh INDEF menyebutkan bahwa hampir sebesar $66,3 \%$ sentimen negatif tertuju bukan hanya kepada pemerintah secara kolektif tetapi kepada Presiden dan Menteri kesehatan, atau hasil survei yang dilakukan oleh change.org yang menyebutkan 69,3\% dengan larangan jika pemerintah jangan menyepelekan masalah Covid- 
19 di awal (Pagiwati, 2020). Padahal kepercayaan dari masyarakat dapat dijadikan modal dalam membangun komunikasi yang partisipatif; yaitu komunikasi yang dilandaskan pada basis sains/pengetahuan.

Kedua, penegakan hukum yang belum optimal. Masyarakat banyak melanggar aturan dengan berbagai alasan. Pemberlakuan sanksi yang diterapkan masih banyak yang bersifat sanksi sosial dan belum diterapkan secara maksimal (Sulasih, 2020). Pemberlakuan sebuah aturan yang tanpa dibarengi oleh pengawasan dan pengawalan ketat, maka tidak akan menimbulkan efek jera bagi para pelanggarnya. Meskipun tataran hukum telah diterbitkan berbagai produk yang mengatur secara detail terkait kebijakan penanggulangan Covid-19, namun masih banyak pelanggaran yang dilakukan oleh masyarakat yang dibiarkan begitu saja. Hal yang menjadi dilematis tentu mengingat pemberlakuan hukuman akan menjadi kontraproduktif jika ditindak dengan hukuman pidana.

Ketiga, partisipasi warga masyarakat yang rendah. Partisipasi adalah faktor penentu efektivitas sebuah kebijakan. Budaya politik partisipan menjadikan individu mampu berperilaku menjaga diri dengan atau tanpa pengawasan dari aparat. Kesadaran yang tinggi dan partisipasi sukarela adalah bagian terpenting dari penanganan Covid-19 selain strategi lainnya. Hal tersebut diakui oleh Presiden Korea Selatan dan ditegaskan kembali oleh Kim Chang Beom, selaku duta besar Korea Selatan untuk Indonesia. Menurutnya, selain melakukan strategi test, trace and treat (lacak, uji dan obat), kesadaran warga menjadi hal yang penting karena di korea Selatan, setiap warga dituntut untuk patuh mengikuti aturan jaga jarak, disiplin melakukan pencegahan pribadi dan selalu mengikuti informasi. Proses pencegahan efektif dan isolasi mandiri tersebut dilakukan dengan menggunakan aplikasi selfdiagnosis dan aplikasi self-quarantin (Beom, 2020)

Keempat, massifnya perkembangan berita hoax terkait Covid-19 di tengah masyarakat. Beredar massif jika Covid-19 adalah konspirasi yang dibuat segelintir pihak demi keuntungan golongan tertentu. Lalu lalang disinformasi tersebut disebabkan oleh kemudahan akses tekhnologi dimana sebaran informasi mudah diakses oleh pengguna tanpa ada filtrasi. Kementrian Komunikasi dan Informasi (Kominfo) menemukan sebanyak 1028 isu hoax yang tersebar di berbagai platform digital (Kominfo, 2020). Hoax hadir dalam berbagai macam narasi pemberitaan berkaitan penyebab, gejala, penyebaran, hingga penyembuhan Covid-19. Hoax tentang teori konspirasi corona semakin beredar di media sosial dan menjadi pesan berantai sehingga dampak bagi perilaku masyarakat. Sikap abai dalam menjaga protokol kesehatan mebuat angka Covid-19 di Indonesia terus menanjak naik. Informasi terkait corona seharusnya berasal dari satu pintu yang terintegrasi sehingga tidak menimbulkan kesimpangsiuran di tengah masyarakat. Adapun sejauh ini penindakan yang dilakukan oleh pemerintah terhadap beredarnya issu corona masih berada dalam tindakan kuratif dengan mengajak perusahan platform digital untuk melakukan takedown (penurunan) terhadap sebaran hoax/disinformasi.

Eskalasi kasus Covid-19 masih terus terjadi dan pelanggaran-pelanggaran terhadap prinsip physical distancing pun terjadi dimana-mana. Hal ini menjadi tanda bahwa kebijakan pemerintah belum ditanggapi secara serius oleh segenap komponen masyarakat. Informasi simpang-siur tentang Covid-19 serta kegagalan memutus rantai persebaran menyebabkan tidak terjadinya perubahan sikap dan perilaku masyarakat. Untuk menyelesaikan masalah yang bersifat national threat, harus ada keputusan yang tepat dan tegas.

\section{PEMBAHASAN}

\section{Perbandingan Kebijakan Indonesia Dan India Dalam Penanganan Covid 19}

Penerapan restriksi wilayah secara ketat oleh India membawa dampak pada pengurangan penularan virus korona dan jumlah kasus yang dilaporkan. Namun efektivitas penguncian tersebut bervariasi antar wilayah dan tergantung oleh banyak faktor, termasuk variable demografis, kepadatan penduduk, dan pertemuan sosial. (Sebastian, Paul, \& 
Vilapurathu, 2020). Sementara itu, lockdown juga telah menimbulkan krisis kemanusiaan dan kekacauan baru akibat eksodus besar-besaran. Seiring berjalannya waktu, pelonggaran lockdown di India dilakukan demi menyelamatkan India dari dari jurang resesi. Hingga bulan Juni,(06/20) perekonomian India mengalami kontraksi dengan kecepatan terjal hingga 23,9\% yang terjadi akibat lockdown diberlakukan (Reuters, 2020). Setelah lockdown dilonggarkan, angka kasus terkonfirmasi covid-19 semakin meningkat di India

Indonesia sendiri memilih untuk menerapkan Pembatasan Sosial Bersakala Besar (PSBB) guna menekan laju covid-19, bukan menerapkan lockdown seperti yang dihimbau oleh WHO. Joko Widodo selaku Presiden menegaskan jika pemerintah daerah harus menerapkan kebijakan yang tidak bertentangan dengan protokol pemerintah pusat. Selain itu, Presiden membentuk satuan Gugus Tugas percepatan penangan Covid-19 guna mempermudah koordinasi pusat hingga ke daerah. Kebijakan tersebut dimulai oleh ibukota Jakarta dan diikuti oleh daerah lainnya. Jika lockdown mengharuskan penduduk untuk tidak keluar rumah sama sekali, PSBB masih memberikan ruang gerak bagi penduduk untuk melakukan aktivitas selagi tidak bertentangan dengan protokol kesehatan.

Table 1 Perbandingan Penanganan Covid-19 Yang Dilakukan Oleh India Dan Indonesia

\begin{tabular}{|c|c|c|}
\hline Jenis Penanganan & Indonesia & India \\
\hline Kasus pertama konfirmasi & 2 Maret 2020 & 30 Januari 2020 \\
\hline Jumlah kasus & 88.214 kasus/(20/7/2020) & $\begin{array}{l}1.116 .597 \\
(20 / 7 / 2020)\end{array}$ \\
\hline $\begin{array}{lll}\begin{array}{l}\text { Rasio } \\
\text { perhari }\end{array} & \text { test/Uji } & \text { Sampel } \\
\end{array}$ & $\begin{array}{l}44.543 \text { spesimen } \\
\text { (rekor terbanyak) }\end{array}$ & $\begin{array}{l}1,2 \text { juta specimen } \\
\text { (rekor terbanyak) }\end{array}$ \\
\hline Angka Fatalitas & 4.239 oraang $(20 / 7 / 2020)$ & $27.593(20 / 7 / 2020)$ \\
\hline Metode & $\begin{array}{l}\text { Pembatasan Sosial Skala } \\
\text { Besar (PSBB) }\end{array}$ & Lockdown \\
\hline Durasi & $\begin{array}{l}30 \text { hari } \\
\text { (tergantung kebijakan } \\
\text { daerah masing2) }\end{array}$ & $\begin{array}{l}45 \text { hari } \\
\text { (25 maret-14 April) } \\
\text { (14 April }-3 \mathrm{Mei}) \\
\text { (4 Mei- } 17 \mathrm{Mei}) \\
(18 \mathrm{Mei}-31 \mathrm{Mei})\end{array}$ \\
\hline Medical treatment & PCR, rapid test & PCR \\
\hline Tecknologi tool & - & Aaragoya Setu \\
\hline Anggaran kesehatan & $2.99 \%$ of GDP & $3.53 \%$ of GDP (2-17/2018) \\
\hline
\end{tabular}

Covid-19 lebih awal dikonfirmasi di India. Dengan jumlah testing yang lebih tinggi di bandingkan Indonesia, kedua negara ini mengalami kendala yang sama yakni rendahnya anggaran kesehatan. Implikasinya adalah, baik Indonesia mapun India memiliki fatalitas kesehatan yang terbatas jika dibandingkan dengan rasio jumlah populasi penduduk. Meskipun begitu, jumlah testing di Indonesia kalah jauh dengan yang sudah dilakukan oleh India. Catatan terkonfirmasi angka kasus di India mengalami lonjakan kasus setelah lockdown dilonggarkan. Hingga tulisan ini diturunkan, India menjadi negara dengan kasus konfirmasi covid-19 tertinggi di Asia.

\section{SIMPULAN}

Indonesia mengambil langkah PSBB yang dalam perjalanannya mengalami penyesuaian durasi untuk berbagai daerah. Sejumlah pelanggaran yang diakibatkan oleh rendahnya kesadaran warga masih sering ditemukan. Meskipun berhasil menekan sementara laju penyebaran Covid, PSBB dinilai tidak cukup efektif. Tantangan serupa dialami oleh India yang sama-sama memiliki populasi penduduk terbesar kedua di dunia. India memilih mengunci negara berpenduduk 1,3 miliar tersebut. Meskipun mampu menekan laju angka 
covid untuk sementara, pemberlakuan karantina wilayah secara mendadak dan minim persiapan telah menimbulkan krisis kemanusiaan. Keputusan penguncian wilayah tersebut berimbas keras pada rakyat miskin di India.

Kepemimpinan yang kuat dalam situasi krisis sangat dibutuhkan untuk memberikan arah penanganan krisis yang jelas dan menumbuhkan kepercayaan publik terhadapa sistem yang dikembangkan untuk melewati masa krisis. Dalam situasi krisis tidak semua pemimpin publik bisa menunjukan kepemimpinan memadai, yang berakibat pada tergerusnya legitimasi kepemimpinan, bahkan bisa menyebabkan krisis kepercayaan terhadap sistem. Pengalaman Indonesia di awal mewabahnya Covid-19 menunjukan salah satu beban terberat adalah politisasi pandemi di antara aktor-aktor kunci pemerintahan. Gagalnya sinergi dan kordinasi antarelemen dalam merespon ancaman pandemi akan dibayar mahal dengan krisis kemanusiaan yang mendalam.

\section{DAFTAR PUSTAKA}

Adam, A., \& Apinino, R. (2020, April 1). Lockdown India Sebabkan Kekacauan, Apa yang Terjadi? Tirto.Id. https://tirto.id/lockdown-india-sebabkan-kekacauan-apa-yang-terjadieJVG

Ambar, W., \& Mas'udi, W. (2020). Dinamika Respons Pemerintah Nasional: Krisis Kebijakan Penanganan Covid-19. dalam W. Mas'udi, \& P. S. Winarti, Tata Kelol Penangan Covid-19 di Indonesia: Kajian Awal (p. 48). Yogyakarta: UGM Press.

BBC News Indonesia. (2020, July 6). Covid-19: Sebulan usai longgarkan lockdown, India jadi negara ketiga dengan kasus terbanyak di dunia. https://www.bbc.com/indonesia/dunia-53306305

Beom, K. C. (2020, April 3). Peduli Sesama dan Bergotong Royong sebagai Kunci -. Kompas.Id. https://kompas.id/baca/opini/2020/04/03/peduli-sesama-dan-bergotongroyong-sebagai-kunci/

Berty, T. T. S. (2020, March 13). WHO Surati Jokowi, Minta RI Umumkan Darurat Nasional Virus Corona COVID-19. Liputan6.Com. https://www.liputan6.com/global/read/4201537/who-surati-jokowi-minta-ri-umumkandarurat-nasional-virus-corona-covid-19

Bhattacharjee, A., Kumar, M., \& Patel, K. K. (2021). When COVID-19 will decline in India? Prediction by combination of recovery and case load rate. Clinical Epidemiology and Global Health, 9, 17-20. https://doi.org/10.1016/j.cegh.2020.06.004

Carina, J. (2020, April 9). Berlaku 14 Hari, Penerapan PSBB di Jakarta Sampai 23 April 2020. KOMPAS.Com. https://megapolitan.kompas.com/read/2020/04/09/23332221/berlaku-14-haripenerapan-psbb-di-jakarta-sampai-23-april-2020

Colangelo, M. (2020, April 16). Deep Analysis Of Global Pandemic Data Reveals Important Insights. Forbes. https://www.forbes.com/sites/cognitiveworld/2020/04/13/covid-19complexity-demands-sophisticated-analytics-deep-analysis-of-global-pandemic-datareveals-important-insights/ 
Davidson, H., Kuo, L., \& McCurry, J. (2020, July 1). The longest holiday: parents coping with coronavirus school closures in east Asia. The Guardian. https://www.theguardian.com/world/2020/mar/03/the-longest-holiday-parents-copingwith-coronavirus-school-closures-in-east-asia

Fakhruroji, M., Tresnawaty, B., Sumadiria, H., \& Risdayah, E. (2020). Strategi komunikasi publik penanganan COVID-19 di Indonesia: Perspektif sosiologi komunikasi massa dan agama. LP2M UIN Sunan Gunung Djati.

Gettleman, J., \& Yasir, S. (2021, January 15). India's Covid Outbreak Is Now the World's Fastest-Growing. The New York Times. https://www.nytimes.com/2020/08/28/world/asia/india-coronavirus.html

Global Democracy Ranking. (2014). Democracy Ranking 2015. Democracy Ranking. http://democracyranking.org/wordpress/rank/democracy-ranking-2015/.

HT Correspondent. (2020, July 19). Coronavirus in India: Highest single-day spike of 40k pushes count past 1.1 million. Hindustan Times. https://www.hindustantimes.com/india-news/highest-single-day-spike-of-40k-pushescount-past-1-1-mn/story-eTLEIMrU8idNSMuxiXmVYK.html

International Growth Center. (2020, May 14). Webinar: The impact of COVID-19 on informal and migrant workers in India[Video]. YouTube. https://www.youtube.com/watch?v=NcVAyxFSt8M

Kikon, D. (2021, January 7). A long way from home. Pursuit. https://pursuit.unimelb.edu.au/articles/a-long-way-from-home

Kluth, A. (2020, March 31). From Orban to Kaczynski, Wannabe Autocrats Love the Pandemic. Washington Post. https://www.washingtonpost.com/business/from-orban-tokaczynski-wannabe-autocrats-love-the-pandemic/2020/03/30/4dd7a89a-72a7-11eaad9b-254ec99993bc_story.html

Kominfo. (2020). Kominfo Mencatat Sebanyak 1.028 Hoaks Tersebar terkait COVID-19. Website Resmi Kementerian Komunikasi Dan Informatika RI. https://kominfo.go.id/content/detail/28536/kominfo-mencatat-sebanyak-1028-hoakstersebar-terkait-covid-19/0/sorotan_media

Kompas. (2020, April 27). Jumlah Pelanggar PSBB Jakarta Periode Awal Capai 32.300 Kendaraan. KOMPAS.Com. https://otomotif.kompas.com/read/2020/04/27/070200315/jumlah-pelanggar-psbbjakarta-periode-awal-capai-32.300-kendaraan

Lal, D. M., \& Pawar, S. D. (2011). Effect of urbanization on lightning over four metropolitan cities of India. Atmospheric Environment, 45(1), 191-196. https://doi.org/10.1016/j.atmosenv.2010.09.027

Laxminarayan, R., Wahl, B., Dudala, S. R., Gopal, K., Mohan B, C., Neelima, S., Jawahar Reddy, K. S., Radhakrishnan, J., \& Lewnard, J. A. (2020). Epidemiology and transmission dynamics of COVID-19 in two Indian states. Science, 370(6517), 691697. https://doi.org/10.1126/science.abd7672 
Mas'udi, W., \& Winarti, P. S. 2020. Tata Kelola Penanganan Covid-19 Di Indonesia Kajian Awal. Yogyakarta: Gajah Mada University Perss.

Muradi, G. F. (2016). DEMOKRASI CIVIL SOCIETY DI INDONESIA DAN INDIA: SEBUAH PERBANDINGAN. Jurnal Wacana Politik, 1(2). https://doi.org/10.24198/jwp.v1i2.11061

Najwa Shihab. (2020, April 22). Jokowi Diuji Pandemi: Didesak Mundur, Menkes Terawan Dipuji Jokowi (Part 1) | Mata Najwa[Video]. YouTube. https://www.youtube.com/watch?v=JFHHzLixfXA

Nursastri, S. A. (2020, April 10). Pakar Peringatkan, Indonesia dan India Berpotensi Jadi Episenter Baru Covid-19. KOMPAS.Com. https://www.kompas.com/sains/read/2020/04/10/180200123/pakar-peringatkanindonesia-dan-india-berpotensi-jadi-episenter-baru-covid

Pagiwati, Rosi Tri. (2020, July 30). Webinar FISIP UI 2020 - Seri 01 : Komunikasi Publik Pemerintah di Masa Pandemi Covid-19[Video]. YouTube. https://www.youtube.com/watch?v=0vwFmk9eHcI

Pai, Chintamani, Bhaskar, A. \& Rawoot V. 2020. "Investigating the Dynamics of COVID-19 Pandemic in India under Lockdown." Chaos, Solitons and Fractals 138: 109988. https://doi.org/10.1016/j.chaos.2020.109988

Paital, B., Das, K., \& Parida, S. K. (2020, September 1). Investigating the dynamics of COVID-19 pandemic in India under lockdown. ScienceDirect. https://linkinghub.elsevier.com/retrieve/pii/S0960077920303878

Reuters. (2020, September 4). GDP contracts by record $23.9 \%$ in Q1. Factly. https://factly.forumias.com/gdp-contracts-by-record-23-9-in-q1/

Saha, J., Barman, B., \& Chouhan, P. (2020). Lockdown for COVID-19 and its impact on community mobility in India: An analysis of the COVID-19 Community Mobility Reports, 2020. Children and Youth Services Review, 116, 105160. https://doi.org/10.1016/j.childyouth.2020.105160

Sebastian, S., Paul, A., Joby, J., Saijan, S., Joseph, J., \& Kunjumon, J. (2020). Impact of Lockdown in India: A Case Study Comparing Karnataka with an International Model. Kesmas-National Public Health Journal. 15(2): 93-98.

Shereen, M. A., Khan, S., Kazmi, A., Bashir, N., \& Siddique, R. (2020). COVID-19 infection: Origin, transmission, and characteristics of human coronaviruses. Journal of Advanced Research, 24, 91-98. https://doi.org/10.1016/j.jare.2020.03.005

Sulasih, E. S. (2020). Ketidakefektifan Penerapan Pembatasan Sosial Berskala Besar (PSBB) di Daerah Khusus Ibukota Jakarta. Binamulia Hukum, 9(1), 67-82. https://doi.org/10.37893/jbh.v9i1.104

Syaodih, S. N. 2007. Metode Penelitian Pendidikan. Bandung: Rosdakarya. 
Tempo. (2020, April 7). Pembatasan Sosial untuk Hentikan Penularan Covid-19. https://nasional.tempo.co/read/1328644/pembatasan-sosial-untuk-hentikan-penularancovid-19

WHO. 2020. 14 World Health Organization Coronavirus Disease 2019 (COVID-19) Situation Report - 42 Data as Reported by 10 AM CET 02 March $2020 \mathrm{H}$. https://www.who.int/docs/default-source/coronaviruse/situation-reports/20200302sitrep-42-covid-19.pdf?sfvrsn=224c1add_2. 


\begin{tabular}{l} 
\\
\hline \hline Info Artikel \\
\hline Dikirim: Okt 26, 2020 \\
Diterima: Jan 27, 2021 \\
Dipublikasi: Jan 31, 2021 \\
\hline Kata Kunci: \\
Desa; \\
Peraturan Desa; \\
Lubuk Larangan; \\
\hline
\end{tabular}

Koresponden:

Bustanuddin

Fakultas Hukum

Universitas Jambi

Email:

bustanuddin@unja.ac.id

Sitasi Cantuman:

Bustanuddin, \& Radjab, D. (2021). Formulasi Pembentukan Peraturan Desa tentang Lubuk Larangan. Journal of Political Issues. 2(2); $\quad$ 102-114. https://doi.org/10.33019/jpi.v $2 \mathrm{i} 2.39$

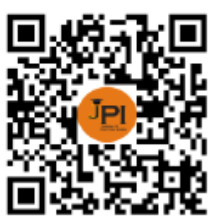

DOI:

https://doi.org/10.33019/jpi.v $2 \mathrm{i} 2.39$

Lisensi:

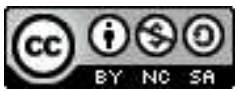

Attribution-NonCommercialShareAlike 4.0 International (CC- BY-NC-SA 4.0)

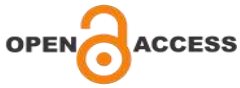

\section{Bustanuddin $^{1 *}$, Dasril Radjab ${ }^{1}$}

${ }^{1}$ Fakultas Hukum, Universitas Jambi, 36361, Jambi-Indonesia

\begin{abstract}
ABSTRAK
Abstract Research on the Formulation of the Formation of Sungai Rotan Village Regulations, Renah Mendaluh Subdistrict, Tanjung Jabung Barat Regency on Lubuk Larangan is based on the problem that is the lack of village regulations that regulate environmental sustainability, especially with regard to prohibition pits. So it is necessary to form a rule that regulates the subject. This study examines how the Formulation of the Establishment of Rotan River Village Regency Renah Mendaluh West Tanjung Jabung Regency About Lubuk Larangan. The establishment of this Village Rule aims to produce a legal product that can provide protection will provide a guarantee of sustainability of the existence of prohibition pits located in the Rotan river Village. The establishment of Village Rules is implemented, as part of the process of implementing local government and village government to realize the sovereignty of the people and sustainable development in accordance with the provisions of the law, which leads to increased welfare and interests of the people and the resolution of problems in society. This research is a normative legal research. This study conducts a study that emphasizes the process of Formulation of the Establishment of Rotan Rivers Village Renah Mendaluh District West Tanjung Jabung Regency About Lubuk Larangan. This study produces a study on the need for village law products for the people of Sungai Rotan Village as a guide in society, especially with regard to the responsibility for environmental sustainability.
\end{abstract}

Abstrak Penelitian mengenai Formulasi Pembentukan Peraturan Desa Sungai Rotan Kecamatan Renah Mendaluh Kabupaten Tanjung Jabung Barat Tentang Lubuk Larangan ini didasarkan pada permasalahan yakni ketidakadanya peraturan desa yang mengatur tentang kelestarian lingkungan khususnya berkenaan dengan lubuk larangan. Sehingga perlu dibentuk suatu aturan yang mengatur perihal tersebut. Penelitian ini mengkaji bagaimana Formulasi Pembentukan Peraturan Desa Sungai Rotan Kecamatan Renah Mendaluh Kabupaten Tanjung Jabung Barat Tentang Lubuk Larangan. Pembentukan Peraturan Desa ini bertujuan untuk mengahsilkan suatu produk hukum yang dapat memberikan perlindungan akan memberikan jaminan kelestarian akan keberadaan lubuk larangan yang terdapat di Desa sungai Rotan. Pembentukan Peraturan Desa dilaksalanakan, sebagai bagian dari proses penyelenggaraan pemerintahan daerah dan pemerintahan desa untuk mewujudkan kedaulatan rakyat dan pembangunan berkelanjutan yang sesuai dengan ketentuan hukum yang berlaku, yang bermuara pada peningkatan kesejahteraan dan kepentingan rakyat dan penyelesaiaan permasalahan dalam masyarakat. Penelitian ini merupakan penelitian hukum normatif. penelitian ini melakukan pengkajian yang menitik beratkan kepada proses Formulasi Pembentukan Peraturan Desa Sungai Rotan Kecamatan Renah Mendaluh Kabupaten Tanjung Jabung Barat Tentang Lubuk Larangan. Penelitian ini menghasilkan suatu kajian akan kebutuhan produk hukum desa bagi masyarakat Desa Sungai Rotan sebagai pedoman dalam bermasyarakat khususnya berkenaan dengan tanggaung jawab akan kelestarian lingkungan hidup.

\section{Tentang:}

Bustanuddin, Penulis menyelesaikan studi S-2 di Magister Ilmu Hukum Universitas Gadjah Mada Pada Tahun 2012, Saat ini Penulis sedang melanjutkan Studi S-3 di Pascasarjana Doktor Ilmu Hukum Universitas Jambi. Penulis saat ini bekerja sebagai Dosen di Fakultas Hukum Universitas Jambi.

Dasril Radjab. Penulis menyelesaikan studi S-2 di Magister Ilmu Hukum Universitas Sumatra Utara Pada Tahun 1997. Penulis saat ini bekerja sebagai Dosen di Fakultas Hukum Universitas Jambi. 


\section{PENDAHULUAN}

Kajian terhadap pembentukan suatu peraturan perundang-undangan, selalu berkaitan dengan konsep norma, konsep kaedah atau konsep hukum. Norma, kaedah atau hukum merupakan suatu ukuran yang harus dipatuhi oleh seseorang dalam hubungannya dengan sesama ataupun lingkungannya (Indrati, 2007). Dalam pandangan Sudikno Mertokesumo suatu norma, kaedah atau hukum itu merupakan suatu perumusan akan pandangan yang bersifat obyektif tentang penilaian atau sikap seyogyanya, seharunya yang dilakukan atau tidak dilakukan, yang dilarang atau dianjurkan untuk dijalankan. Pada suatu posisi suatu kaedah hukum lazim diartikan sebagai peraturan hidup yang menentukan bagaimana manusia atau kita seyogyanya serta seharunya berperilaku, bersikap didalam masyarakat agar kepentingannya dan kepentingan orang lain akan selalu terlindungi (Mertokesumo, 2007). Amiroeddin Syarif berpandangan bahwa suatu norma, kaedah atau merupakan suatu patokan atau standar yang didasarkan kepada ukuran nilai-nilai tertentu (Syarif, 1987).

Pembentukan suatu peraturan perundang-undangan dalam pandangan M Solly Lubis bahwa pembentukan suatu peraturan merupakan suatu proses akan pembentukan sebuah peraturan negara. Memperhatikan kondisi ini maka tata cara dan tahapan dalam pembentukan peraturan perundang-undangan yang berlaku di Indonesia, dimulai dari tahapan perencanaan, tahap pembahasan, tahap pengesahan dan tahap penetapan dan tahap akhirnya pengundangan peraturan yang bersangkuta, (Lubis, 1995). selanjutnya ketika akan membicarakan berkaitan tentang berlakunya suatu peraturan perundang-undangan yang akan dibentuk dalam pandangan Purnadi Purwacaraka dan Soerjono Soekanto dikenal beberapa azas-azas atau konsep seperti i. azas pembentukan peraturan perundang-undangan tidak berlaku surut; ii. Azas pembentukan peraturan perundang-undangan dibuat oleh penguasa yang lebih tinggi, mempunyai kedudukan yang lebih tinggi pula; iii. azas pembentukan peraturan perundangundangan yang bersifat khusus menyampingkan peraturan perundang-undangan yang bersifat umum. Azas Peraturan perundang-undangan yang berlaku belakangan membatalkan Peraturan perundang-undangan yang berlaku terdahulu, azas pembentukan peraturan perundang-undangan tidak dapat diganggu gugat, serta azas pembentukan peraturan perundang-undangan sebagai sarana untuk semaksimal mungkin dapat mencapai kesejahteraan spirituil dan materiel bagi masyarakat maupun individu melalui pembaharuan atau pelestarian (Purbacaraka \& Soekanto, 1993).

Hal senada diungkapkan oleh Amiroeddin Syarif ketika menguatkan konsep tersebut yang menyatakan asas-asas peraturan perundang-undangan yakni asas pembentukan peraturan perundang-undangan berdasarkan Asas Tingkatan Hirarki, asas pembentukan Peraturan perundang-undangan tidak dapat diganggu gugat, asas pembentukan peraturan perundang-undangan yang bersifat khusus mengenyampingkan peraturan perundangundangan yang bersifat umum, asas pembentukan peraturan perundang-undangan tidak berlaku surut; dan asas pembentukan peraturan perundang-undangan yang baru mengenyampingkan Peraturan perundang-undangan yang lama (Syarif, 1987).

Didalam pembantukan suatu peraturan perundang-undangan, termasuk dalam pembentukan peraturan desa Disamping adanya asas-asas pembentukan perundang-undangan dan asas materi muatan peraturan perundang-undangan yang diatur dalam ketentuan yang berlaku. Suatu peraturan perundang-undangan yang baik hendaknya harus memiliki tiga landasan dan dasar yakni landasan dasar Filosofis, landasan dasar sosiologis dan landasan dasar yuridis. Dalam pembentukan peraturan perundang-undangan termasuk peraturan desa selain ketiga asas dan fondasi dasar tersebut ada juga yang menambahnya dengan landasan teknik perancangan dan landasan politis (Ranggawidjaja, 1998). Hal senada seperti disampaikan oleh M. Solly Lubis dalam bukunya yang menyatakan bahwa dalam pembuatan dan pembentukan sutau peraturan negara ada tiga dasar atau landasan yang harus dipenuhi dalam rangka pembuatan segala peraturan, pada tiap jenis dan tingkat yaitu landasan Filosofis, landasan yuridis dan landasan politis (Lubis, 1995). Kondisi yang membedakan 
antara pandangan-pandangan tersebut yakni M. Solly Lubis memasukan landasan Politis, sedangkan Rosjidi Ranggawidjaja memasukan landasan sosiologis. Ketentuan-ketentuan tersebut nantinya akan menjadi sebuah ketentuan dan keputusan yang tertulis berkenan pembentukan peraturan perundang-undangan.

Disisi lain ketika membicarakan konsep norma, kaedah atau hukum maka tidak lepas membicarak suatu peraturan. Suatu Peraturan merupakan suatu ketentuan umum yang ditujukan kepada hal-hal yang masih abstrak (Wirjosoegito, 2004). Dalam hal ini membicarakan hal dan angan-angan yang dicita-citakan ketika menjalankan suatu urusan. Suatu delegasi dalam pembuatan suatu peraturan berarti pembuat peraturan maka peraturan yang lebih tinggi memberi wewenang kepada pembuat peraturan yang lebih rendah. UndangUndang Dasar (Grondwet) memberi wewenang atau delegasi kepada Undang-Undang (wet) (Hardjowidigdo, 2004). Kewenangan dalam pembuatan peraturan perundang-undangan diatribusikan atau diserahkan atau dibagi berdasarkan ketentuan dalam aturan dasar bernegara yang terdapat dalam Undang-Undang Dasar suatu negara maupun dalam ketentuan UndangUndang dalam arti Formil. Pada saat Undang-Undang Dasar atau Undang-Undang dalam arti formil dengan tegas menentukan atau memberi wewenang untuk itu (Hardjowidigdo, 2004). Ketika suatu peraturan yang dibawahnya secara hierarki bertentangan dengan peraturan diatasnya maka suatu aturan itu dapat dibatalkan atau batal demi hukum.

Berkenaan Pembentukan Peraturan Perundang-Undangan dinyatakan bahwa dalam membentuk peraturan perundang-undangan termasuk peraturan desa harus berdasarkan pada asas pembentukan peraturan Perudang-undangan yang baik dan benar yang meliputi adanya kejelasan tujuan, kelembagaan atau organ pembentuk yang tepat, kesesuaian antara jenis dan materi muatan, dapat dilaksanakan, kedayagunaan dan kehasilgunaan, kejelasan rumusan, dan keterbukaan.

Selanjutnya ditentukan materi muatan suatu peraturan perandang-undangan termasuk peraturan desa harus mengandung asas pengayoman, kemanusian, kebangsaan, kekeluargaan, kenusantaraan, bhinneka tunggal ika, keadilan, kesamaan kedudukan dalam hukum dan pemerintahan, ketertiban dan kepastian hukum; dan/atau, keseimbangan, keserasian, dan keselarasan. Termasuk dalam pembentukan peraturan terkait permasalahan lingkungan dan kehutanan.

Berkaitan dengan kondisi kehutanan dimana hutan, sungai, danau, laut, dan apa yang ada didalamnya merupakan kekayan alam yang dimiliki oleh Negara Kesatuan Republik Indonesia. Kekayaan yang melimpah merupakan sumber penghidupan masyarakat Indonesia. Provinsi Jambi dan Kabupaten Tanjung Jabung Barat secara khusus memiliki kekayaan alam yang melimpah yang menjadi sumber penghidupan masyarakat Kabupaten Tanjung Jabung seperti potensi, kelapa sawit, karet, Padi, hasil perikanan dan lain sebagainya. Sehingga perlu diatur dengan peraturan tertentu demi untuk menjaga kelestariannya dan keberadaanya tidak disalahgunakan oleh pihak yang tidak bertanggung jawab..

Hutan dengan segala isinya merupakan sebuah karunia dan amanat sang pemilik dunia dan akhirat yang menganugerahkan segala kemudahan akan sumber daya kehutanan kepada warga Negara dan masyarakat Indonesia. Hutan dan segala isinya dalam satuan wilayah Negara merupakan kekayaan yang dikuasai dan dikelola oleh Negara. Negara dalam hal ini harus memberikan manfaat yang serbaguna bagi umat manusia atau warga Negara Indonesia, karenanya wajib disyukuri, diurus, dan dimanfaatkan secara optimal, serta dijaga kelestariannya untuk kemakmuran, bagi generasi sekarang maupun generasi mendatang. Pembangunan sumber daya kehutanan dan sumber daya alam hayati, hutan dan ekosistemnya pada hakikatnya adalah bagian integral dari pembangunan nasional yang berkelanjutan sebagai pengamalan Pancasila yang tak terpisahkan. Selain itu unsur-unsur sumber daya alam hayati dan ekosistemnya pada dasarnya saling tergantung antara satu dengan yang lainnya dan saling mempengaruhi sehingga kerusakan dan kepunahan salah satu unsur akan berakibat terganggunya ekosistem. Berkaitan dengan kondisi inilah kondisi kehutanan dan lingkuang 
seperti hutan, sungai, danau dan sumber daya alam lainnya harus di proteksi sejak dini dengan peraturan perundang-undangan sampai tingkat terbawah yang mengatur perihal urusan-urusan pemerintahan sampai ketinggkat desa.

Berkenaan dengan permasalahan tersebut telah diatur dalam ketentuan UndangUndang Dasar Negara yang menyatakan bahwa bumi, air dan kekayaan alam yang terkandung di dalamnya dikuasai oleh negara dan dipergunakan untuk sebesar-besarnya kemakmuran rakyat, maka pengelolaan sumberdaya alam berupa hutan, sungai harus berorientasi kepada konservasi sumberdaya alam untuk menjamin kelestarian dan keberlanjutan fungsi sumberdaya alam, dengan menggunakan pendekatan yang bercorak komprehensif dan terpadu.

Pembentukan peraturan perundang-undangan terkait dan termasuk peraturan desa merupakan suatu perwujudan untuk membentuk suatu Negara hukum yang berorientasi untuk menjaga kelestasrian alam dan lingkungan hidup. Kondisi ini dikarenakan bahwa suatu Negara hukum atau sering disebut dengan rechsstaat menurut Philipus Hadjon adalah suatu negara yang keberadaannya lahir dari suatu perjuangan menentang absolutisme sehingga sifatnya revolusioner dan bertumpu pada atas sistem kontinental yang disebut dengan system hukum civil law. Negara hukum dalam pandangan lain memiliki suatu konsep adanya i. perlindungan terhadap hak asasi manusia, ii. adanya pemisahan kekuasaan dalam negara, dan iii. setiap tindakan negara harus berdasarkan undang-undang yang dibuat terlebih dahulu serta iv. ketika memiliki peradilan administrasi untu menyelesaikan perselisihan antara penguasa dan rakyat (Kumpulan Makalah, 2003). Selanjutnya akan diatur lebih lanjut dengan peraturan-peraturan yang ada dibawahnya termasuk peraturan desa.

Sehingga ketika akan mendirikan sebuah Negara hukum, kemudian membuat hukum dan menjalankan hukum, maka tidak akan bisa dilepaskan dari rancangan besar mengenai bagaimana kehidupan manusia itu dibangun dalam sebuah negara. Bahwa suatu negara hukum itu dibangun untuk merancang sebuah kehidupan rakyat yang mensejahterakan dan membahagiakan. Sehingga bagaimana negara hukum Indonesia ini merancang kehidupan sekian ratus juta rakyatnya menjadi pintu masuk bagi legislasi dinegeri ini (Rahardjo, 2006).

Selian itu Hukum merupakan lembaga yang bekerja dalam masyarakat, dimana ketika bekerja dalam masyarakat hukum memiliki tiga perspektif yakni, hukum sebagai kontrol, hukum sebagai social engineering dan hukum sebagai emansipasi masyarakat terhadap hukum. (Rahayu, 2014) Dengan kondisi seperti ini maka ketika akan menerapkan sebuah Negara Hukum maka suatu negara itu hendaknya mempunyai dua tugas utama yakni yang pertama mengorganisir dan menngintegrasikan kegiatan manusia dan golongan-golongan kearah tercapainya tujuan-tujuan dari masyarakat seluruhnya. Negara menentukan bagaimana kegiatan asosial-asosial kemasyarakatan disesuaikan satu sama lain dan diarahkan ketujuan nasional dan yang kedua mengendalikan dan mengatur gejala-gejala kekuasaan yang asosial, yakni yang bertentangan satu sama lain, supaya tidak menjadi antagonisme yang membahayakan (Budiardjo, 2008).

Sehingga pada suatu titik, maka negara yang berdasarkan atas hukum atau Rechtsstaats pada umumnya akan bercirikan sebuah Negara yang berdemokrasi konstitusionil, dimana Undang-undang dasar mempunyai mempunyai fungsi yang khas yaitu membatasi kekuasaan pemerintah sedemikian rupa sehingga penyelenggaraan kekuasaan tidak bersifat sewenang-wenang. Dengan demikian dharapankan hak-hak warga negara akan lebih terlindungi (Budiardjo, 2008).

Indonesia sebagai negara hukum yang berbentuk Republik terdiri atas wilayahwilayah yang tersebar dari sabang sampai merauke dari tingkatan provinsi dampai ketingkat desa. Desa sebagai bagian dari pemerintahan terkecil di Indonesia layaknya pemerintahan provinsi dan kabupaten juga memiliki peraturan yang dinamakan dengan peraturan desa. Peraturan desa merupakan Salah satu komponen dalam menjalankan konsep Negara hukum 
pada tingkat desa yakni dengan keberadaan suatu peraturan perundang-undangan, yang dinamakan peraturan desa.

Provinsi Jambi terdiri atas beberapa kabupaten/kota, salah satunya Kabupaten Tanjung Jabung Barat. Salah satu desa yang terdapat di Kabupaten Tanjung Jabung Barat adalah Desa Sungai Rotan. Desa Sungao Rotan secara geografis terbentang diwilayah Tanjung Jabung Barat yang memiliki potensi hutan alam, perikanan sungai dan air tawar yang melimpah. Dalam rangka pengelolaan pengelolaan Hutan, sungai dan kekayaan alam yang ada di Desa Sungai Rotan Kecamatan Renah Mendaluh Kabupaten Tanjung Jabung Barat perlu dibentuk sebuah konsep pengelolaan kehutanan dengan pendekatan khusus yang disebut dengan konsep Lubuk Larangan. Konsep lubuk larangan ini nanti akan diatur dengan peraturan desa Sungai Rotan Kecamatan Renah Mendaluh yang berorientasi kepada kepentingan umum. Menyikapi kondisi ini perlu dilakukan pengkajian terhadap Implementasi Pembentukan Peraturan Desa Sungai Rotan Kecamatan Renah Mendaluh Kabupaten Tanjung Jabung Barat Tentang Lubuk Larangan.

Berkaitan dengan pembentukan peraturan, alah satu produk hukum yang digunakan untuk mengatur perilaku kehidupan bermasyarakat selain undang-undang, peraturan daerah, terdapat juga peraturan desa yang dapat digunakan sebagai acuan dalam pedoman kemasyarakatan ditingkat Desa. Peraturan Desa yang dapat dibentuk merupakan peraruran desa yang mengatur kondisi khusus yang terdapat di desa-desa. Salah satu peraturan desa yang dapat dibuat adalah peraturan desa berkenaan dengan kemasyarakatan adat suatu desa atau mengatur hal-hal khusus didesa tersebut seperti pengaturan tentang kondisi kehutanan adat dan lingkungan adat.

Lubuk larangan merupakan suatu konsep pemanfaataan lingkungan yang diganakan masyarakat desa dalam rangkan kelestarian lingkungan alam setempat. Lubuk larangan merupakan konsep khusus kehutanan yanga berada di Provinsi Jambi. Keberadaan kehutanan dan lingkungan alam serta perairan dengan konsep lubuk larangan merupakan hal khusus yang perlu dijaga dengan baik dengan perlindungan yang diberikan dengan menetapkan suatu kebijakan tertentu dalam suatu aturan seperti peraturan desa.

Berkenaan dengan latar belakang tersebut maka, kajian penelitian ini akan menganalisis Apakah kerangka hukum yang relevan untuk Implementasi Pembentukan Peraturan Desa Sungai Rotan Kecamatan Renah Mendaluh Kabupaten Tanjung Jabung Barat Tentang Lubuk Larangan? Serta Formulasi kebijakan apakah yang perlu dirumuskan oleh Pemerintah Daerah terhadap Implementasi Pembentukan Peraturan Desa Sungai Rotan Kecamatan Renah Mendaluh Kabupaten Tanjung Jabung Barat Tentang Lubuk Larangan. Rumusan permasalahan ini dirumuskan dengan tujuan untuk Memformulasikan Pembentukan Peraturan Desa Sungai Rotan Kecamatan Renah Mendaluh Kabupaten Tanjung Jabung Barat Tentang Lubuk Larangan. Sehingga memberikan pedoman dalam pelaksanaan kebijakan ke depan untuk perlindungan dan kesejahteraan masyarakat khususnya masyarakat Desa Sungai Rotan Kecamata Kecamatan Renah Mendaluh Kabupaten Tanjung Jabung Barat.

\section{METODE PENELITIAN}

Metode penelitian yang digunakan dalam penelitian ini merupakan penelitian hukum normatif. Dalam penelitian ini akan diteliti asas-asas, prinsip, norma dan isi kaidah hukum dari peraturan perundang-undangan berkaitan dengan Pembentukan peraturan desa. Metode pendekatan yang digunakan untuk melakukan penelitian ini yaitu menggunakan pendekatan peraturan perundang-undangan (statute approach), dan pendekatan konseptual (conceptual approach) (Marzuki, 2012). Pendekatan Peraturan perundang-undangan akan dilakukan metode penelaahan terhadap semua perundang-undangan yang terkait dengan permasalahan yang akan dilakukan penelitian. Selain pendekatan perundang-undangan, penelitian ini dilakukan juga dengan pendekatan konseptual, yaitu: penelitian yang beranjak dari 
pandangan-pandangan dan doktrin-doktrin tentang perlindungan hukum khususnya untuk petani dan nelayan tradisional yang berkecimpung dalam pemanfaatan lubuk dan perairan tawar yang ada di Desa Sungai Rotan. Adapun peraturan perundang-undangan yang akan dianalisis meliputi peraturan yang terkait dengan pembentukan peraturan Desa Sungai Rotan Tentang Lubuk Larangan. Ketentuan-ketentuan tersebut berorientasi kepada urgensi dan teori mengenai pluralisme hukum untuk dianalisis akan pengaruh dan relevansinya dalam pembentukan tata hukum lokal dan nasional, sehingga menghasilkan peraturan desa yang sesuai dengan ketentuan peraturan perundang-undangan yang berlaku.

\section{HASIL PENELITIAN DAN PEMBAHASAN}

Prinsip Penyelenggaraan Pemerintahan Desa

Desa atau yang disebut dengan nama lain, selanjutnya disebut Desa, adalah kesatuan masyarakat hukum yang memiliki batas-batas wilayah yang berwenang untuk mengatur dan mengurus kepentingan masyarakat setempat berdasarkan asal-usul dan adat istiadat setempat yang diakui dan dihormati dalam sistem Pemerintahan Negara Kesatuan Republik Indonesia. Pemerintahan desa merupakan lembaga perpanjangan pemerintah pusat memiliki peran yang strategis dalam pengaturan masyarakat desa/kelurahan dan keberhansilan pembangunan nasional, maka perlu adanya peraturan-peraturan atau Undang-Undang yang berkaitan dengan pemerintahan desa yang mengatur tentang pemerintahan desa, sehingga roda pemerintahan berjalan dengan optimal.

Dalam undang-undang tentang desa dinyatakan bahwa Desa adalah kesatuan masyarakat hukum yang memiliki batas wilayah yang berwenang untuk mengatur dan mengurus urusan pemerintahan, kepentingan masyarakat setempat berdasarkan prakarsa masyarakat, hak asal usul, dan/atau hak tradisional yang diakui dan dihormati dalam sistem pemerintahan Negara Kesatuan Republik Indonesia. Selanjutnya dinyatakan bahwa Pemerintahan Desa adalah penyelenggaraan urusan pemerintahan dan kepentingan masyarakat setempat dalam sistem pemerintahan Negara Kesatuan Republik Indonesia. Penyelenggaraan pemerintahan desa menurut undang-undang desa dikatakan bahwa Pemerintah Desa adalah Kepala Desa atau yang disebut dengan nama lain dibantu perangkat Desa sebagai unsur penyelenggara Pemerintahan Desa. artinya bahwa pemerintahan desa diselenggarakan oleh pemerintah desa.

Penyelenggaraan pemerintahan desa pada prinsipnya menurut undang-undang tentang Nomor 6 Tahun 2014 Tentang Desa bertujuan untuk:

a. memberikan pengakuan dan penghormatan atas Desa yang sudah ada dengan keberagamannya sebelum dan sesudah terbentuknya Negara Kesatuan Republik Indonesia;

b.memberikan kejelasan status dan kepastian hukum atas Desa dalam sistem ketatanegaraan Republik Indonesia demi mewujudkan keadilan bagi seluruh Rakyat Indonesia;

c. memberikan kejelasan status dan kepastian hukum atas Desa dalam sistem ketatanegaraan Republik Indonesia demi mewujudkan keadilan bagi seluruh rakyat Indonesia;

d.melestarikan dan memajukan adat, tradisi, dan budaya masyarakat Desa;

e. mendorong prakarsa, gerakan, dan partisipasi masyarakat Desa untuk pengembangan potensi dan Aset Desa guna kesejahteraan bersama;

f. membentuk Pemerintahan Desa yang profesional, efisien dan efektif, terbuka, serta bertanggung jawab;

g. meningkatkan pelayanan publik bagi warga masyarakat Desa guna mempercepat perwujudan kesejahteraan umum;

h. meningkatkan ketahanan sosial budaya masyarakat Desa guna mewujudkan masyarakat Desa yang mampu memelihara kesatuan sosial sebagai bagian dari 
ketahanan nasional;

i. memajukan perekonomian masyarakat Desa serta mengatasi kesenjangan pembangunan nasional; dan

j. memperkuat masyarakat Desa sebagai subjek pembangunan.

Keberadaan sebuah Desa memiliki keanekaragaman disesuaikan dengan asal usul budaya yaitu: (1) Keanekaragaman, disesuaikan dengan asal usul dan kondisi sosial budaya masyarakat setempat, (2) partisipasi, bahwa penyelenggaraan pemerintahan dan pembangunan desa harus mampu mewujudkan peran aktif masyarakat agar senantiasa memiliki bertanggung jawab terhadap perkembangan kehidupan bersama sebagai sesama warga desa, (3) otonomi asli, bahwa kewenangan pemerintah desa dalam kewenangan, bahwa kewenangan pemerintah desa dalam mengatur dan mengurus masyarakat setempat didasarkan hak asal usul dan nilai-nilai sosial budaya yang terdapat pada masyarakat setempat namun dalam perspektif administrasi desa(4) Demokrasi, artinya Penyelenggaraan pemerintahan dan pelaksana pembangunan di desa harus menampung aspirasi-aspirasi masyarakat dimusyawarakan dan kemudian dipilih untuk dilaksanakan melalui BPD dan Lembaga Kemasyarakatan sebagai mitra Pemerintah Desa (5) Pemberdayaan Masyarakat, artinya Penyelenggaraan dan pembangunan di desa ditujukan untuk meningkatkan taraf hidup dan kesejahteraan masyarakat melalui penetapan kebijakan, program dan kegiatan yang sesuai dengan pokok masalah dan prioritas kebutuhan masyarakat (Ali Fauzan, 2010).

Disamping itu penyelenggaraan pemerintahan desa harus dilaksanakan dengan konsep kepemimpinan yang tepat sehingga tujuan penyelenggaran pemerintahan desa berjalan lancar. Pelaksanaan "kepemimpinan" berdasar atas pandangan Kartono, Keating, Heywood, dan Yukl dapat diartikan sebagai berikut, yaitu sosok individu yang punya kemahiran dankeunggulan serta kapabilitas keefektifan tindakan sehingga ia kuasa memengaruhi individu atau kelompok masyarakat agar bekerja sama dalam melaksanakan praktik-praktik tertentu ataupun untuk mencapai satu dan/atau banyak misi yang dikehendaki (Mayrudin, dkk, 2020).

Pemerintahan Desa juga merupakan proses dari hasi sebuah demokrasi dimana demokrasi bisa dilihat sebagai satu perangkat praktek dan prinsip yang sudah dilembagakan dan selanjutnya melindungi kebebasan itu sendiri. Demokrasi yang melibatkan konsensus di dalamnya, namun secara minimal persyaratan demokrasi terdiri dari: pemerintahan yang dipilih dari suara mayoritas dan memerintah berdasarkan persetujuan masyarakat, keberadaan pemilihan umum yang bebas dan adil, proteksi terhadap kaum minoritas dan hak asasi dasar manusia, persamaan perlakuan di mata hukum, proses pengadilan dan pluralisme politik. Artinya demokrasi tidak hanya sekedar melibatkan kebebasan masyarakat dalam sistem politik, akan tetapi lebih dari itu sampai dengan tata cara melibatkan rakyat dalam demokrasi. Termasuk dalam pembentukan peraturan yang akan diberlakukan dalam pemerintahan desa (Primadi, dkk, 2019).

\section{Formulasi Pembentukan Peraturan Desa Tentang Lubuk Larangan}

Penyelenggaraan Pemerintahan Desa Merupakan bagian tidak terpisahkan dari penyelenggaraan pemerintahan daerah. Selayaknya pemerintahan daerah, pemerintahan desa juga memiliki aturan yang mengatur tentang penyelenggaraan pemerintahan desa yang disebut dengan peraturan desa. Pembentukan Peraturan Desa tidak jauh berbeda dengan pembentukan peraturan perundang-undangan lainnya seperti peraturan daerah.

Pembentukan peraturan perundang-undangan menurut Jimly Asshiddiqie yang dikutip oleh Yuliandri menyangkut empat bentuk kegiatan, yaitu : pertama, prakarsa pembuatan perundang-undangan (legislative initiation); kedua pembahasan rancangan perundang-undangan (law making process); ketiga, persetujuan atas pengesahan rancangan peraturan perundang-undangan (law enactmen approval); dan keempat pemberian 
persetujuan pengikatan atau ratifikasi atas perjanjian atau persetujuan internasional dan dokumen-dokumen hukum yang mengikat lainnya (binding decision making on international law agreement and treaties or other legal binding documents) (Yuliandri, 2009).

Berkenaan dengan pembuatan peraturan perundang-undangan, Burkhardt Krems dalam A Hamid Attamimi menyatakan bahwa dalam bidang hukum yang menyangkut pembentukan peraturan perundang-undangan negara, maka pembentukan peraturan perundang-undangan itu menyangkut (i) isi peraturan, (ii) bentuk dan susunan peraturan, (iii) metode dan pembentukan peraturan dan (iv) prosedur dan proses pembentukan peraturan (Attamimi, 1990). Selanjutnya I.C. Van der Vlies Menyatakan bahwa ketentuan-ketentuan yang harus diperhatikan oleh pembuat peraturan perundang-undangan dalam membuat peraturan perundang-undangan terdapat dalam satu tempat dan saling berurutan. Ketentuanketentuan yang terpenting terdapat diberbagai tempat dalam peraturan perundang-undangan menyangkut isi maupun prosedur (Vlies, 2005). Proses pembuatan peraturan perundangundangan termasuk peraturan desa Suangi Rotan Tentang Lubuk Larangan didalamnya disesuaikan dengan prosedur dan ketentuan yang yang telah ditetapkan.

Dari paparan di atas jelaslah bahwa faktor keberadaan produk hukum di daerah seperti Peraturan Desa yang baik yang sesuai dengan ketentuan yang berlaku merupakan salah satu faktor yang sangat menentukan bagi keberhasilan pelaksanaan otonomi daerah dan penyelanggaraan pemerintahan daerah di desa. Dengan kata lain, salah satu ciri dari daerah otonom dan penyelenggaraan pemerintahan desa terletak pada kemampuan self supportingnya dalam acuan hukumnya, termasuk di dalamnya adalah kemampuan penyelenggara desa dalam membuat produk hukum Desa Sungai Rotan Kecamatan Renah Mendaluh Kabupaten Tanjung Jabung Barat Tentang Lubuk Larangan yang tepat dan sesuai dengan kondisi desa. Serta menyelengarakan Implementasi Pembentukan Peraturan Desa Sungai Rotan Kecamatan Renah Mendaluh Kabupaten Tanjung Jabung Barat Tentang Lubuk Larangan sesuai dengan tujuan yang dikehendaki. Keberadaan produk hukum desa yang mengatur tentang lubuk larangan yang tepat dan sesuai akan memperlancar dan mempermudah dalam penyelenggaraan pemerintahan desa yang bertujuan untuk mempercepat proses kesejahteraan masyarakat di desa sungai rotan. Keberadaan produk hukum desa berkenaan dengan pengutan tentang lubuk larangan juga berfungsi dalam mengatur serta meningkatkan pendapatan desa Sungai Rotan serta meningkatkan berbagai program-program pembangunan dalam melaksanakan berbagai fungsinya secara baik dan benar, seperti fungsi pelayanan kepada masyarakat (public services), fungsi pembangunan (development), dan fungsi perlindungan kepada masyarakat (society protec-tion). Pengaturan berkaitan Pembentukan Peraturan Desa Sungai Rotan Kecamatan Renah Mendaluh Kabupaten Tanjung Jabung Barat Tentang Lubuk Larangan yang tepat akan menjadikan proses pembangunan daerah desa Sungai Rotan Kecamatan Renah Mendaluh Kabupaten Tanjung Jabung Barat akan berkembang dengan cepat dan baik.

Oleh karena itu dalam upaya merealisasikan tujuan penyelenggaraan dan peningkatan pembangunan daerah dan desa yang baik, diperlukan produk hukum desa berkaitan Implementasi Pembentukan Peraturan Desa Sungai Rotan Kecamatan Renah Mendaluh Kabupaten Tanjung Jabung Barat Tentang Lubuk Larangan yang baik sebagai salah satu acuan dalam penyelanggaraan pemerintahan desa Sungai Rotan.

Berdasarkan pemikiran sebagaimana diuraikan di atas, pembentukan Peraturan Desa memperhatikan ketentuan undang-undang nomor 12 tahun 2011 tentang pembentukan peraturan perundang-undangan dan undang-undang nomor 6 tahun 2014 tentang Desa pembentukan peraturan desa diperlukan dalam rangka:

1. Kejelasan dan Kepastian hukum bagi pemeritahan daerah desa Suangi Rotan Kecamatan Renah Mendaluh Kabupaten Tanjung Jabung Barat Tentang Lubuk Larangan yang sesuai dengan ketentuan yang berlaku;

2. Kesesuain produk hukum Desa tentang Tata Cara Pembentukan Peraturan Desa 
Sungai Rotan Kecamatan Renah Mendaluh Kabupaten Tanjung Jabung Barat Tentang Lubuk Larangan yang dihasilkan dan mempermudah koordinasi serta kelancaran proses penyelenggaraan pemerintahan desa dalam rangka perlindungan lubuk larangan di desa Suangi Rotan;

3. Kejelasan tugas, wewenang, dan tanggung jawab pemerintahan Desa dalam pembangunan Desa Sungai Rotan Kecamatan Renah Mendaluh Kabupaten Tanjung Jabung Barat serta menjamin kelestarian alam yakni Lubuk Larangan.

4. Kejelasan dan kepastian hukum bagi pemerintahan desa dan atau masyrakat desa dalam mengajukan proses Pembentukan Peraturan Desa Sungai Rotan Kecamatan Renah Mendaluh Kabupaten Tanjung Jabung Barat Tentang Lubuk Larangan yang bertujuan memberikan perlindungan terhadap masalah lingkungan khususnya berkaitan dengan lubuk larangan.

Tujuan pembentukan peraturan desa selaras dengan ketentuan Undang-Undang Tentang Pembentukan Peraturan Perundang-undangan yang menjelaskan bahwa produk hukum termasuk peraturan desa merpakan bagian dari peraturan perundang-undangan. Peraturan perundang-undangan meruapakan peraturan tertulis yang dibentuk oleh lembaga negara atau pejabat yang berwenang dan mengikat secara umum sedangkan Materi muatan Peraturan perundang-undangan adalah materi yang dimuat dalam Peraturan perundangundangan sesuai dengan jenis, fungsi dan hierarki Peraturan perundang-undangan.

Proses pembuatan Peraturan Perundang-Undangan yang pada dasarnya dimulai dari perencanaan, persiapan, tekhnik penyusunan, perumusan, pembahasan, pengesahan, pengundangan dan penyebarluasan dalam rangka penyelenggaraan pemerintahan daerah diatur dalam undang-undang pembentukan peraturan perundang-undangan yakni UndangUndang Republik Indonesia Nomor 10 Tahun 2004 Tentang Pembentukan Peraturan Perundang-undangan yang telah diubah dengan Undang-Undang Republik Indonesia Nomor 12 Tahun 2011 Tentang Pembentukan Peraturan Perundang-undangan.

Berkaitan dengan penyelanggaran pemerintahan daerah dalam konsep otonomi daerah yang dituangkan dalam Undang-Undang Nomor 22 tahun1999 tentang Pemerin-tahan Daerah yang kemdian disempurnakan dengan diundangkan UU No. 32 Tahun 2004 tentang Pemerintahan Daerah dan diubah dengan Undang-Undang Nomor 23 tahun 2014 tentang Pemerintahan Daerah.

Dengan ditetapkannya Undang-Undang Nomor 23 tahun 2014 tentang Pemerintahan Daerah, paradigma pembangunan daerah berubah menjadi paradigma daerah membangun yang didekati dengan prinsip: (i) pelaksanaan otonomi daerah yang luas, nyata, dan bertanggung jawab; (ii) asas keseimbangan pertumbuhan antar daerah serta antar desa dan kota; (iii) pemberdayaan masyarakat; serta (iv) pendayagunaan potensi sumber daya alam dengan berpegang pada kelestarian lingkungan hidup. Lebih jauh diungkapkan bahwa pemberian otonomi daerah dan desentralisasi fiskal dari pemerintah pusat ke daerah dimaksudkan untuk mempercepat pembangunan daerah agar dapat tercipta, antara lain: (i) peningkatan pelayanan dan kesejahteraan seluruh masyarakat di daerah; (ii) berkembangnya kehidupan yang demokratis yang disertai dengan peningkatan peran serta masyarakat dalam perencanaan pembangunan di daerah; serta (iii) terpeliharanya hubungan yang serasi antara pusat dan daerah serta antardaerah dalam rangka menjaga keutuhan Negara Kesatuan Republik Indonesia (Soedjito, 2002).

Peraturan tentang Pemerintahan Daerah ini mengisyaratkan adanya 4 (empat) pilar yang mendukung pelaksanaan otonomi daerah dan desentralisasi fiskal, yaitu: (i) kapasitas aparat daerah; (ii) kapasitas kelembagaan daerah; (iii) kapasitas keuangan daerah, dan (iv) kapasitas lembaga nonpemerintah di daerah. Dari keempat pilar dapat terlaksana dengan adanya pedoman yang tertuang dalam produk hukum daerah yang konkrit dan nyata yang dijadikan pedoman dan prosedur dalam penyelenggaraan pemerintahan daerah. Selain itu 
pembentukan peraturan Desa merupakan bagian dari kesatuan tertib hukum ini dalam proses pembentukan hukum yang bersifat hierarkis dan dinamis. (Nasution, 2018)

Pelaksanaan otonomi daerah yang dititikberatkan pada Daerah Kabupaten dan Daerah Kota dimulai dengan adanya penyerahan sejumlah kewewenangan (urusan) dari pemerintah pusat ke pemerintah daerah yang bersangkutan. Penyerahan berbagai kewenangan dalam rangka desentralisasi ini tentunya harus disertai dengan diberikannya kewenangan untuk membuat pedoman sendiri yang tertuang dalam produk hukum daerah yang dibuat oleh penyelenggara pemerintahan daerah.

Ada sementara pihak yang memandang bahwa keberhasilan pelaksanaan otonomi daerah akan ditentukan oleh adanya 5 (lima) kondisi strategis yang meliputi: (i) Self Regular Power, dalam arti kemampuan mengatur dan melaksanakan otonomi daerah demi kepentingan masyarakat di daerahnya; (ii) Self Modifying Power, berupa kemampuan menyesuaikan terhadap peraturan yang telah ditetapkan secara nasional sesuai dengan kondisi daerah termasuk terobosan inovatif ke arah kemajuan dalam menyikapi potensi daerah; (iii) Creating Local Political Support, dalam arti penyelenggaraan pemerintahan daerah yang mempunyai legitimasi kuat dari masyarakatnya, baik pada posisi kepala daerah sebagai Eksekutif maupun DPRD sebagai pemegang kekuasaan Legislatif; (iv) Managing Financial Resources, dalam arti mampu mengembangkan kompetensi dalam mengelola secara optimal sumber penghasilan dan keuangan guna pembiayaan aktivitas pemerintahan, pembangunan dan pelayanan kepada masyarakat; serta (v) Developing Brain Power, dalam arti membangun SDM (Sumber Daya Manusia) yang handal dan selalu bertumpu pada kapabilitas dalam menyelesaikan masalah (Suwardyono, 2000).

Secara umum, faktor-faktor yang akan menentukan dan mempengaruhi keberhasilan pelaksanaan otonomi daerah di Indonesia, antara lain yaitu: (i) faktor manusia sebagai subjek penggerak (faktor dinamis) dalam penyelenggaraan otonomi daerah; (ii) faktor keuangan yang merupakan tulang punggung bagi terselenggaranya aktivitas pemerintahan daerah; (iii) faktor peralatan yang merupakan sarana pendukung bagi terselenggaranya aktivitas pemerintahan daerah; serta (iv) faktor organisasi dan manajemen yang merupakan sarana untuk melakukan penyelenggaraan pemerintahan daerah secara baik, efisien, dan efektif (Kaho, 1997).

Dari paparan di atas jelaslah bahwa faktor dan keberadaan produk hukum sangat menentukan bagi keberhasilan pelaksanaan otonomi daerah. Dengan kata lain, salah satu ciri dari daerah otonom terletak pada kemampuan self supporting-nya dalam bidang pembentukan produk hukum daerah yang baik dan sesuai dengan kebutuhan masyarakat daerah. Kondisi ini dapat terlaksana dengan adanya pedoman pembentukan produk hukum peraturan desa pada setiap desa.

Desa Sungai Rotan Merupakan salah satu desa yang terletak di Kecamatan Renah Mendalu Kabupaten Tanjung Jabung barat yang memiliki potensi alam berupa aliran suangai yang biasa disebut lubuk yang sangat menyokong perekonomian Desa Sungai Rotan dan sekitarnya. Kondisi aliran sungai di desa Sungai Rotan perlu di proteki dengan aturan desa yang mengatur tentang pedoman dan pemanfaatn sungai yang biasa disebut dengan larangan. Jaminan perlindungan terhadap aliran sungai dan lingkungan yang adan disekitar Desa Sangai Rotan dimungkina jika ada aturan tertentu yang mengatur tentang itu. Kondisi ini tentunya dapat terlaksana dengan adanya pedoman penyelenggraan pemerintahan desa yang tertuang dalam produk hukum peraturan desa yang dijabar kedalam pembentukan Peraturan Desa Sungai Rotan Kecamatan Renah Mendaluh Kabupaten Tanjung Jabung Barat Tentang Lubuk Larangan. Kemampuan pemerintah daerah dalam penyelenggaraan pemerintahan daerah yang baik akan sangat ditentukan oleh keberadaan dari produk hukum yang mengatur berbagai program-program pembangunan daerah bagaimana daerah dalam melaksanakan berbagai fungsinya secara baik dan benar, seperti fungsi pelayanan kepada masyarakat (public services), fungsi pembangunan (development), dan fungsi perlindungankepada 
masyarakat (society protec-tion) sesuai ketentuan yang tertuang dalam produk hukum daerah tersebut.

Pemanfaatan sumber daya alam yang terdapat di desa Sungai Rotan selama ini belum terkelola dengan baik. Masyarakat Desa Sungai Rotan dalam pemenuhan kebutuhan seharihari dalam pemanfaatn air sungai dan hutan tidak memperhatikan kelestarian hutan dan sungai yang berada di wilayah desa. Penangkapan ikan banyak dilakukan dengan memberi tuba ikan dan menggunakan alat setrum yang bisa mengakibatkan benih-benih ikan yang belum layak panen menjadi ikut mati. Selain itu pemanfaat air sungai oleh masyarakat juga tidak terjaga dengan baik. Dalam kehidupan sehari-hari pemanfaat sungai selain untuk kebutuhan lauk-pauk juga untuk pemanfaat sebagai tempat untuk mandi, cuci dan kakus. Pemanfaatan untuk mandi, cuci, dan kakus sekaligus sering tidak dijaga kebersihannya, dimana deterjen dan sabun bekas cucian tetap mengalir dan mengendap di sungai sehingga zat-zat kimia sisa dari mencuci dan mandi terlanjur mengkontaminasi air sungai. Kondisi ini mengakibatkan kondisi air sungai tidak lagi steril untuk dimanfaatkan untuk kebutuhan sehari-hari. Memperhatikan kondisi ini, perlu dibuat peraturan secara khusus dan pengelolaan sumber daya sungai dengan model tertentu diterapkan di Desa Sungai Rotan. Hak-hak tradisional yang ada diakui dan dijunjung tinggi. Hak-hak tradisional ini meliputi hak ulayat, hak-hak memperoleh manfaat atau kenikmatan dari tanah dan air atau hasil hutan dan lainlain sekitarnya. (Huda: 2015).

Keberadaan peraturan Desa Tentang Lubuk Larangan diharapkan dapat menjaga kelestarian lingkungan alam dan sungai yang ada didesa Sungai Rotan sehingga dapat dimanfaatkan oleh masyarakata secara berkelanjutan. Kelestarian hutan dan juga sungai yang ada didesa sungai rotan dengan konsep lubuk larangan dapat meningkatkan proses pembangunan desa Sungai Rotan itu sendiri. Dalam upaya merealisasikan tujuan pembangunan daerah didesa Sungai Rotan Kecamatan Renah Mendaluh Kabupaten Tanjung Jabung Barat, diperlukan Peraturan Peraturan Desa Sungai Rotan Kecamatan Renah Mendaluh Kabupaten Tanjung Jabung Barat Tentang Lubuk Larangan, yang secara umum akan mengatur dan menjadi pedoman dalam rangka penyelenggaraan pemerintahan daerah khususnya Penyelenggaran Pemerintahan Desa Sungai Rotan Kecamatan Renah Mendaluh Kabupaten Tanjung Jabung Barat.

Kondisi dilapangan dalam proses pembentukan peraturan desa tentang lubuk larangan, terdapat dualisme kepentingan masyarakat dan pihak penyelenggara desa. Satu sisi lubuk larangan merupakan fasilitas tradisional yang selalu dimanfaatkan masyarakat untuk kebutuhan sehari-hari, disisi lain pemerintah desa menginginkan kelestarian lubuk larangan terjaga dengan baik dengan pemanfaat lubuk larangan dengan mempedomani peraturan desa yang akan dibuat.

Pembentukan peraturan desa tentang lubuk larangan merupakan perwujudan dalam mendistribusikan hak dan kewajiban, tujuan legislator atau pembentukan peraturan yang menginginkan kebahagian masyarakat, dengan menempatkan empat tujuan pembentukan hukum yakni, sumber nafkah, kemakmuran, kesetaraan dan rasa aman dalam kehidupan bermasyarakat. (Bentham, 2019). Tujuan akhir pembentukan peraturan daerah tentang lubuk larangan ini adalah untuk kelestarian lingkungan, terutama di Desa Sungai Rotan. Pengaturan ini memberikan perlindungan akan kelestarian lingkungan hukum. Kondisi ini diwujudkan karena perlindungan dan pengelolan lingkungan Hidup merupakan upaya manusia untuk berinteraksi dengan lingkungan guna mempertahankan kehidupan, mencapai kesejahteraan dan kelestarian lingkungan. (Helmi, 2012). Hal ini selaras dengan Fungsi Negara Modern yang disampaikan oleh Jimly Asshiddiqie mencakup 4 dimensi yakni sumber daya dalam wilayah Negara, hukum dan keadilan, legitimasi dan demokrasi, serta kesejahteraan. (Asshiddiqie, 2018). Bahwa pembentukan peraturan peraturan desa tentang lubuk larangan ini berorientasi kepada kesejahteraan lingkungan dan kesejahteraan masyarakat Sungai Rotan Kecamatan Mendaluh Kabupaten Tanjung Jabung Barat. 


\section{SIMPULAN}

Keberadaan produk hukum desa yang mengatur tentang lubuk larangan yang tepat dan sesuai akan memperlancar dan mempermudah dalam penyelenggaraan pemerintahan desa yang bertujuan untuk mempercepat proses kesejahteraan masyarakat di desa sungai rotan. Keberadaan produk hukum desa berkenaan dengan pengaturan tentang lubuk larangan juga berfungsi dalam mengatur serta meningkatkan pendapatan desa Sungai Rotan serta meningkatkan berbagai program-program pembangunan dalam melaksanakan berbagai fungsinya secara baik dan benar, seperti fungsi pelayanan kepada masyarakat (public services), fungsi pembangunan (development), dan fungsi perlindungan kepada masyarakat (society protec-tion). Pengaturan berkaitan Pembentukan Peraturan Desa Sungai Rotan Kecamatan Renah Mendaluh Kabupaten Tanjung Jabung Barat Tentang Lubuk Larangan yang tepat akan menjadikan proses pembangunan daerah desa Sungai Rotan Kecamatan Renah Mendaluh Kabupaten Tanjung Jabung Barat akan berkembang dengan cepat dan baik. Pembentukan Peraturan Desa Sungai Rotan bertujuan untuk menjaga kelestarian lingkungan Desa Sungai Rotan khususnya berkenaan dengan kelestarian akan keberadaan Lubuk Larangan.

\section{DAFTAR PUSTAKA}

Asshiddiqie, J. (2018). Konstitusi Keadilan Sosial. Jakarta: Kompas Media Nusantara.

Attamimi, A. H. S. (1990). Peranan Keputusan Presiden Republik Indonesia dalam Penyelenggaran Pemerintahan Negara: Suatu Studi Analisa Mengenai Keputusan Presiden yang Berfungsi Pengaturan dalam Kurun Waktu Pelita I - Pelita IV. Disertasi pada Fakultas Pascasarjana Universitas Indonesia.

Bentham, J. (2019). Teori Perundang-Undangan Prinsip-Prinsip Legislasi Hukum Perdata Dan Hukum Pidana. Bandung: Nuansa Cendikia.

Budiardjo, M. (2008). Dasar-Dasar Ilmu Politik. Jakarta: PT. Gramedia.

Fauzan, A. (2010). Implementasi peraturan pemerintah Nomor 72 tahun 2005 tentang desa Terkait dengan peran badan permusyawaratan desa Dalam penyusunan dan penetapan Peraturan Desa Di Kecamatan Wanasari Kabupaten Brebes (Doctoral dissertation, UNIVERSITAS DIPONEGORO).

Hardjowidigdo, R. (2004). Wetgevingsleer di Negeri Belanda dan Perkembangan UndangUndang saat ini di Indonesia. Jakarta: Badan Pembinaan Hukum Nasional Departemen Hukum dan Hak Aasi Manusia.

Helmi. (2012). Hukum Perizinan Lingkungan Hidup. Jakarta: Sinar Grafika.

Huda, N. M. (2015). Hukum Pemerintahan Desa. Hukum Pemerintahan Desa. Bandung: Nusa Media.

Indrati, M. F. (2007). Ilmu Perundang-undangan 1. Yogyakarta: Penerbit Kanisius.

Kaho, J. R. (1997). Prospek Otonomi Daerah di Negara Republik Indonesia. Jakarta: PT Raja Grafindo Persada. 
Kumpulan Makalah, (2003). Hukum dan Hak Asasi Manusia Jilid I. Bandung, PPs Unpad.

Lubis, M. S. (1995). Landasan dan Teknik Perundang-Undangan. PT. Mandar Maju, Bandung.

Marzuki, P. M. (2012). Penelitian Hukum. Jakarta: Kencana.

Mayrudin, Y., Husna, N., \& Yuliati, F. (2020). Formal and Informal Leadership Power Contestation in Public Policy and Daily Politics. Journal of Political Issues, 2(1), 1-9. https://doi.org/10.33019/jpi.v2i1.30

Mertokesumo, S. (2007). Penemuan Hukum sebuah pengantar. Yogyakarta: PT. Liberty.

Nasution, B. J. (2011). Negara Hukum dan Hak Asasi Manusia. Mandar Maju.

Primadi, A., Efendi, D., \& Sahirin, S. (2019). Peran Pemilih Pemula Dalam Pengawasan Pemilu Partisipatif. Journal of Political Issues, 1(1), 63-73. https://doi.org/10.33019/jpi.v1i1.7

Purbacaraka, P. \& Soekanto, S. (1993). Perundang-Undangan dan Yurisprudensi, ,Bandung: PT. Citra Aditya Bakti.

Rahardjo, S. (2006). Hukum dalam Jagat Ketertiban. Jakarta: UKI PRESS

Rahayu, D. P. (2014). Budaya Hukum Pancasila. Yogyakarta: Thafa Media.

Ranggawidjaja, R. (1998). Pengantar Ilmu Perundang-Undangan Indonesia. Bandung: Penerbit Mandar Maju.

Soedjito, Bambang Bintoro, Kondisi Keuangan Daerah Dalam Pembangunan Daerah, Makalah disampaikan pada Workshop Sehari dengan tema: Pembangunan Daerah dan Alternatif Pembiayaannya, yang diadakan atas kerjasama antara SIAGA Project UGMBES-BAPPENAS, Jakarta: 23 April 2002.

Suwardyono, E. W. (2000). Kesiapan Jawa Timur dalam Proses Desentralisasi Fiskal: Suatu Kajian Pendahuluan. Lokakarya Nasional Strengthening the University Capacity to Support Decentralization. Jakarta.

Syarif, A. (1987). Perundang-undangan, Dasar, Jenis Dan Teknik Pembuatannya. Jakarta: PT. Bina Aksara.

Vlies, I. C. V. d. (2005). Perancang Peraturan Perundang-Undangan. Terjemahan oleh Linus Doludjawa. Jakarta: Direktorat Jenderal Peraturan Perundangundangan Departemen Hukum dan Hak Asasi Manusia.

Wirjosoegito, S. (2004). Proses \& Perencanaan Peraturan Perundangan. Jakarta: Ghalia Indonesia.

Yuliandri. (2009). Asas-asas Pembentukan Peraturan Perundang-undangan Yang Baik. Jakarta: PT. Raja Grafindo Persada. 


\section{Tindakan Pencegahan Pembakaran Hutan dalam Perspektif ASEAN Community}

\begin{tabular}{|c|c|}
\hline \multicolumn{2}{|r|}{$\begin{array}{l}\text { Retno Kusniati }^{1} \text {, Bunga Permatasari }{ }^{1 *} \text {, Mohamad Rapik } \\
{ }^{1} \text { Fakultas Hukum, Universitas Jambi, 36361, Jambi-Indonesia }\end{array}$} \\
\hline Info Artikel & ABSTRAK \\
\hline $\begin{array}{l}\text { Dikirim: Okt 25, } 2020 \\
\text { Diterima: Jan } 18,2021 \\
\text { Dipublikasi: Jan } 31,2021 \\
\end{array}$ & $\begin{array}{l}\text { Abstract This article aims to elaborate on the values of the ASEAN Community in } \\
\text { preventing forest and land fires through the ASEAN Agreement Transboundary Haze } \\
\text { Pollution (AATHP), and the Implementation of AATHP in Indonesia. This is because the }\end{array}$ \\
\hline $\begin{array}{l}\text { Kata Kunci: } \\
\text { ASEAN; } \\
\text { Hutan; } \\
\text { Lahan; } \\
\text { Pembakaran; }\end{array}$ & $\begin{array}{l}\text { causes cross-border air pollution which results in disruption of diplomatic relations } \\
\text { among the ASEAN Member States. Even though ASEAN Member countries have agreed to } \\
\text { create an ASEAN Community. Therefore, by applying the normative juridical legal } \\
\text { research method, this paper intends to explore several things, namely first; how the values } \\
\text { of the ASEAN Community in preventing forest and land fires through the ASEAN }\end{array}$ \\
\hline $\begin{array}{l}\text { Koresponden: } \\
\text { Bunga Permatasari } \\
\text { Fakultas Hukum } \\
\text { Universitas Jambi }\end{array}$ & $\begin{array}{l}\text { of AATHP in Indonesia. This article finds that the values of the ASEAN Community have } \\
\text { been contained in every article regulated in the AATHP for the prevention of forest and } \\
\text { land fires that occur in the ASEAN region. Second, Indonesia has ratified the AATHP and } \\
\text { made legal products that can reach actors of forest and land burning. This is marked by } \\
\text { the passing of the Law on Environmental Protection and Management, the Forestry Law, } \\
\text { the Plantation Law, and the Law on Prevention and Eradication of Forest Destruction. } \\
\text { Besides, in Jambi Province, Jambi Province has also established Local Regulation } \\
\text { Number } 2 \text { of } 2016 \text { concerning Prevention and Control of Forest and Land Fires. }\end{array}$ \\
\hline
\end{tabular}

\section{Sitasi Cantuman:}

Kusniati, R., Permatasari, B., \& Rapik, M. (2021). Tindakan Pencegahan Pembakaran Hutan dalam Perspektif ASEAN Community. Journal of Political Issues. 2(2); 115 123.

https://doi.org/10.33019/jpi.v $2 \mathrm{i} 2.37$

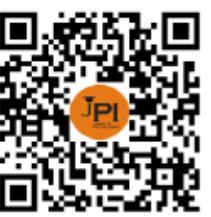

DOI:

https://doi.org/10.33019/jpi.v $2 \mathrm{i} 2.37$

Lisensi:

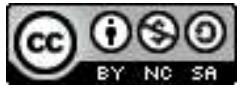

Attribution-NonCommercialShareAlike 4.0 International (CC- BY-NC-SA 4.0)

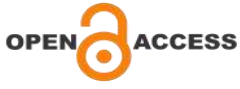

Abstrak Artikel ini bertujuan untuk memaparkan tentang nilai-nilai ASEAN Community dalam pencegahan pembakaran hutan dan lahan melalui ASEAN Agreement Transboundary Haze Pollution (AATHP), dan Implementasi AATHP di Indonesia. Hal ini disebabkan karena Persoalan Kebakaran hutan dan Lahan merupakan salah satu isu utama di kawasan ASEAN, dan dampaknya menimbulkan pencemaran udara lintas batas negara yang mengakibatkan terganggunya hubungan diplomatik diantara Negara Anggota ASEAN. Padahal negara Anggota ASEAN bersepakat untuk mewujudkan ASEAN Community. Oleh karena itu, dengan menerapkan metode penelitian hukum yuridis normatif, tulisan ini hendak menjelajahi beberapa hal, yaitu pertama; bagaimana nilai-nilai nilai-nilai ASEAN Community dalam pencegahan pembakaran hutan dan lahan melalui AATHP, Kedua, bagaimana implementasi AATHP di Indonesia. Artikel ini menemukan bahwa nilai-nilai ASEAN Community telah tertuang dalam setiap pasal yang diatur dalam AATHP guna pencegahan kebakaran hutan dan lahan yang terjadi pada kawasan ASEAN, Kedua, Indonesia telah meratifikasi AATHP dan membuat produk hukum yang dapat menjangkau para pelaku pembakaran hutan dan lahan. Hal ini ditandai dengan disahkannya UU Perlindungan dan Pengelolaan Lingkungan Hidup, UU Kehutanan, UU Perkebunan, dan UU Pencegahan dan Pemberantasan Perusakan Hutan. Selain itu, di Provinsi Jambi, juga membentuk Peraturan Daerah Provinsi Jambi Nomor 2 Tahun 2016 tentang Pencegahan Dan Pengendalian Kebakaran Hutan Dan Lahan.

\section{Tentang:}

Retno Kusniati, menyelesaikan studi Magister (S2) Universitas Sriwijaya pada tahun 2004. Saat ini penulis adalah mahasiswa Program Pascasarjana Doktor Ilmu Hukum Universitas Jambi dan dosen Fakultas Hukum di Universitas Jambi.

Bunga Permatasari, menyelesaikan studi Magister (S2) Universitas Jambi pada tahun 2014. Saat ini penulis adalah dosen Fakultas Hukum di Universitas Jambi

Mohamad Rapik, menyelesaikan studi Magister (S2) pada dua Institusi yaitu IAIN Sultan Thaha Saifudin Jambi pada tahun 2003 dan Universitas Jambi pada tahun 2012. Saat ini penulis adalah mahasiswa Program Pascasarjana Doktor Ilmu Hukum Universitas Jambi dan dosen Fakultas Hukum di Universitas Jambi. 


\section{PENDAHULUAN}

Hutan adalah anugerah tak ternilai dari Tuhan. Oleh karena itu manusia memiliki tanggung jawab untuk melindungi dan melestarikannya dengan antara lain menghindari menyebabkan kerusakan di bumi ini agar tidak hanya dilestarikan untuk hari ini tetapi juga di masa depan (Gusliana,2019). Peristiwa bencana El Nino yang mengakibatkan hangusnya hutan seluas 25 juta hektar (ha) di seluruh dunia, membuat isu lingkungan terkait kebakaran hutan menarik perhatian International (Tacconi, 2003).

Kebakaran hutan dan lahan merupakan ancaman bagi pembangunan berkelanjutan karena dampaknya secara langsung terhadap ekosistem(UNISDR 2002), kebakaran tersebut, berkontribusi terhadap peningkatan emisi karbon yang memicu perubahan iklim dan berdampak pada produktivitas dan mengancam keanekaragaman hayati (Sommers, Loehman, \& Hardy, 2014).

Di Asia Tenggara, permasalahan mengenai dampak kebakaran hutan mendapat perhatian yang serius dengan disepakatinya Agreement on Transboundary Haze Pollution (AATHP) untuk mencegah dan menanggulangi pencemaran asap lintas-batas oleh negara anggota ASEAN. Selain itu, dalam kerja sama ASEAN di bidang lingkungan hidup, salah satu focus utamanya adalah penyelesaian kabut asap lintas batas negara (Yudha dkk, 2017).

Indonesia pernah menjadi sorotan dunia tahun 1997-1998 akibat kebakaran hutan dan lahan yang terjadi cukup lama. Negara Asean terutama Thailand, Filipina, dengan Malaysia dan Singapura yang paling terpengaruh akibat asap dari kebakaran hutan dan lahan tersebut (Schweithelm, \& Barber, 2000). Kebakaran besar hutan dan lahan terulang kembali di 2015 dan 2019. laporan dari Lembaga Penerbangan dan Antariksa Nasional memperkirakan luas hutan dan lahan Indonesia yang terbakar Tahun 2015 mencapai 2.089.911 hektar (ha) yang terdiri dari 618.574 ha lahan gambut dan 1.471.337 (ha) lahan non gambut. Selain itu, Bank Dunia mencatat total kerugian yang diakibatkan bencana kabut asap itu mencapai Rp 221 triliun (Tempo, 2016).

Shannon N Koplitz mengemukakan ada 100.300 kasus kematian yang disebabkan oleh kebakaran hutan di Indonesia pada September-Oktober 2015. Dari jumlah itu diperkirakan 91.600 (24.000-159.200) di Indonesia, 6.500 (1.700-11.300) di Malaysia, dan 2200 (660-3.800) di Singapura (Koplitz, dkk., 2016). Berbeda dengan yang disampaikan oleh Kepala Pusat Data dan Informasi dan Humas Badan Nasional Penanggulangan Bencana (BNPB) Sutopo Purwo Nugroho, ada sebanyak 24 orang yang meninggal dunia akibat peristiwa kebakaran hutan dan lahan tersebut (Putri, 2015).

Tahun 2019 peristiwa kebakaran hutan dan lahan pun kembali terulang. Bukan Indonesia saja yang mengalami kebakaran hutan dan lahan yang besar, melainkan beberapa Negara di ASEAN pun juga turut terbakar hutannya. Di Thailand, Kebakaran telah menghancurkan hutan sebanyak 2.7 juta rai yang berada di 9 Provinsi Thailand Utara (The Thaiger, 2019)' Selain itu, diberitakan bahwa asap kebakaran hutan dan lahan Indonesia telah menyebar hingga ke Thailand Selatan (Perdana, 2019) dan kawasan resort Phuket (Asmardika, 2019).

Kebakaran hutan dan lahan ini dipicu oleh kebiasaan masyarakat dan para pemegang perkebunan menggunakan metode slash and burn (Potter, Padoch, \& Peluso, 1996) dalam membuka lahan. Selain itu, aktivitas ini juga dilakukan dalam rangka transformasi pembukaan lahan transmigrasi (Schweithelm, \& Barber, 2000), industri perkebunan dan palawija (Barr, 2001), dan lahan perkebunan ke kelapa sawit (Schweithelm, \& Barber, 2000). Menurut Kemen G Austin, Amanda Schwantes, Yaofeng Gu, dan Prasad S Kasibhatla menunjukkan bahwa ekspansi perkebunan kelapa sawit dari tahun 2001-2016 menyebabkan hilangnya 23 persen hilangnya tutupan hutan Indonesia (Virgy, Djuyandi, \& Darmawan, 2020). Selain itu, Under Fire (Greenpeace Indonesia, 2015) yang dikeluarkan pada November 2015 menyebutkan perusahaan-perusahaan pemasok minyak kelapa sawit Wilmar International melakukan deforestasi melalui metode pembakaran lahan hutan dan 
menyebabkan dampak kesehatan yang masif terhadap masyarakat sekitar (Virgy, Djuyandi, \& Darmawan, 2020).

Kenyataannya, berdasarkan hukum internasional, pencemaran udara lintas batas negara akibat kebakaran hutan dan lahan akan menjadi tanggung negara sebagaimana ditegaskan dalam Prinsip 21 Deklarasi Stockholm 1972 bahwa:

"States have, in accordance with the Charter of the United Nations and the principles of international law, the sovereign right to exploit their own resources pursuant to their own environmental policies, and the responsibility to ensure that activities within their jurisdiction or control do not cause damage to the environment of other States or of areas beyond the limits of national jurisdiction."

Di sisi ini lain terkait pula dengan prinsip "Sic Utere Tuo Alienum Non Laedas (Seseorang harus menggunakan miliknya dengan tidak menimbulkan kerugian terhadap orang lain)"(Triadmodjo, 2000) yang menentukan bahwa "No state has the right to use or permit the use of its territory in such a manner as to cause injury by fumes in or to the territory of another and that measures of control were necessary"(Kamil, 1999)

Pasal 2 huruf (a) Undang-Undang Nomor 32 Tahun 2009 tentang Pengelolaan dan Perlindungan Lingkungan Hidup (UUPLH) mengatur bahwa Perlindungan dan pengelolaan lingkungan hidup dilaksanakan berdasarkan asas tanggung jawab Negara. Provinsi Jambi, turut bertanggung jawab dalam pencemaran udara akibat kebakaran hutan dan lahan. Berdasarkan Data Warsi, terdapat 30.947 titik api. 157.137 (ha) hutan dan lahan di Jambi terbakar, yang mana hutan 101.418 (ha) merupakan hutan gambut. Dan ini lebih buruk dari tahun 2015, 90.363 hutan gambut yang terbakar serta kerugian lingkungan 12 triliun rupiah (Suprapto \& Suryadi, 2020).

Padahal Hutan Gambut di Provinsi Jambi mempunyai nilai penting bagi dunia, karena mampu menyimpan setidaknya 57 miliar ton karbon. dan Kawasan hutan gambut yang terbakar, salah satunya ada di kawasan Taman Nasional Berbak yang merupakan kawasan pelestarian alam untuk konservasi hutan rawa terluas di Asia Tenggara.

Kewajiban untuk mengambil langkah pencegahan dan penanggulangan diatur dalam Pasal 3 ayat (3) AATHP bahwa:

"The Parties should take precautionary measures to anticipate, prevent and monitor tranboundary haze pollution as a result of land and/or forest fires which should be mitigated, to minimise its adverse effects. Where there are threats of serious or irreversible damage from transboundary haze pollution, even without full scientific certainty, precautionary measures shall be taken by Parties concerned."

Kewajiban tersebut ditegaskan kembali dalam ketentuan Pasal 4 bahwa:

"When the transboundary haze pollution originates from within their territories, respond promptly to a request for relevant information or consultations sought by a State or States that are or may be affected by such transboundary haze pollution, with a view to minimising the consequences of the transboundary haze pollution. Take legislative, administrative and/or other measures to implement their obligations under this Agreement."

Kebakaran hutan dan lahan yang berakibat pada pencemaran udara lintas batas negara tersebut tentunya akan menghalangi tujuan dari pembentukan ASEAN Community. Masyarakat ASEAN yang secara resmi diberlakukan pada tanggal 31 Desember 2015 memiliki tujuan tidak hanya mempertahankan stabilitas keamanan kawasan dan meningkatkan kesejahteraan rakyat, tetapi sekaligus mendorong terciptanya masyarakat yang berpandangan maju, hidup dalam lingkungan yang damai, stabil, sejahtera, demokratis serta 
saling peduli dan melindungi hak asasi dan keadilan sosial (Direktorat Jenderal Kerjasama ASEAN, 2018).

Oleh karena itu, berdasarkan persoalan yang ditimbulkan oleh pencemaran udara lintas batas negara yang terjadi di ASEAN akibat kebakaran hutan dan lahan, artikel ini berupaya menelusuri bagaimana nilai-nilai ASEAN Community dalam pencegahan pembakaran hutan dan lahan dalam AATHP, Kedua, bagaimana implementasi AATHP di Indonesia.

\section{METODE PENELITIAN}

Artikel ini menggunakan metode penelitian yuridis normatif. Adapun pendekatan yang dilakukan meliputi pendekatan perundang-undangan, pendekatan konseptual, dan pendekatan analitis (Sinamo, 2009). Pengumpulan dan Penelusuran bahan-bahan hukum yang relevan menggunakan sistem mendeley. Bahan hukum terkumpul diindentifikasi dengan cara studi bahan-bahan hukum dan studi dokumen yang relevan. Bahan hukum hakekat, asas-asas, konsepsi-konsepsi, doktrin hukum serta substansi norma hukum dalam pencegahan dan penanggulangan kebakaran hutan dan lahan dikumpulkkan melalui referensi yang bersifat:1) umum yaitu buku hukum, dan review hukum dan internasional, dan 2) khusus berupa jurnal hukum. Studi dokumen merujuk dan dilakukan pada dokumen public yang resmi dan terpecaya.

\section{HASIL PENELITIAN DAN PEMBAHASAN}

\section{Upaya Pencegahan Pembakaran Hutan Dan Lahan Dalam Perspektif nilai-nilai ASEAN Community.}

ASEAN Charter (Piagam ASEAN) telah ditetapkan sebagai statuta dasar ASEAN menggantikan Deklarasi ASEAN. Perubahan ini berakibat secara de jure ASEAN menjadi organisasi kawasan yang berdasarkan aturan (Puspita, 2015). Selain itu, ASEAN juga membentuk ASEAN Community. ASEAN Community ini dibentuk dengan tiga pilar utama. Ketiga pilar tersebut Mayarakat Sosial Budaya ASEAN, Masyarakat Ekonomi ASEAN, dan Masyarakat Keamanan ASEAN. Dari ketiga pilar tersebut, Masyarakat Sosial Budaya ASEAN yang merupakan salah satu pilar ditandai eksistensinya melalui cetak biru masyarakat Sosial Budaya ASEAN yang memiliki karakterisitik atau nilai yaitu: engages and benefits people, inclusive, sustainable, resilient, dynamic.(Direktorat Jenderal Kerjasama ASEAN, 2018)

Jauh sebelum disahkannya ASEAN Community tersebut, nilai-nilai Masyarakat Sosial Budaya ASEAN yang berupa engages and benefits people, inclusive, sustainable, resilient, dynamic (Direktorat Jenderal Kerjasama ASEAN, 2018) dapat ditemukan semangat nilai tersebut dalam AATHP. Kebakaran Hutan dan Lahan yang terjadi di Indonesia dan Negara anggota ASEAN merupakan salah satu tantangan yang dihadapi masyarakat Sosial budaya ASEAN sejak sebelum ASEAN community terbentuk. Dan AATHP merupakan salah satu cara yang ditempuh oleh negara anggota ASEAN guna memperkuat kerja sama kawasan dalam pengelolaan hutan secara berkelanjutan dalam konteks pencegahan dan pengendalian kebakaran hutan yang dapat menyebabkan pencemaran udara lintas batas Negara melalui Penandatanganan AATHP. Meskipun tiap-tiap negara ASEAN memiliki respon yang berbeda-beda dalam meratifikasi AATHP tesebut. Hal ini dapat terlihat dalam tabel di bawah. 
Table 1 Negara Yang Telah Meratifikasi AATHP

\begin{tabular}{ccc}
\hline Negara Anggota & Tanggal Ratifikasi & $\begin{array}{c}\text { Tanggal Penyerahan } \\
\text { Ratifikasi }\end{array}$ \\
\hline Brunei Darussalam & 27 Febuari 2003 & 23 April 2003 \\
Kamboja & 24 April 2006 & 9 November 2006 \\
Filipina & 1 Febuari 2010 & 4 Maret 2010 \\
Myanmar & 5 Maret 2003 & 17 Maret 2003 \\
Thailand & 10 September 2003 & 26 September 2003 \\
Myanmar & 5 Maret 2003 & 17 Maret 2003 \\
Laos & 19 Desember 2004 & 13 Juli 2005 \\
Indonesia & 16 September 2014 & 20 Januari 2015 \\
Malaysia & 3 Desember 2002 & 18 Febuari 2003 \\
Vietnam & 24 Maret 2003 & 29 Mei 2003 \\
\hline
\end{tabular}

Sumber: ASEAN Haze Action, 2015

Pada intinya, nilai-nilai ASEAN yang terdapat AATHP merupakan wujud nyata sense of community. Sense of Community didefinisikan sebagai "a feeling that members have of belonging, a feeling that members matter to one another and to the group, and a shared faith that members' needs will be met through their commitment to be together" (McMillan \& Chavis, 1986) yang dapat diartikan rasa kebersamaan adalah perasaan yang dimiliki anggota, perasaan bahwa anggota itu penting satu sama lain dan untuk kelompok, dan keyakinan bersama bahwa kebutuhan anggota akan terpenuhi komitmen mereka untuk bersama.

Untuk itu sense of community dari ASEAN Community mempunyai motto ASEAN: One Vision, One Identity, One Community. Oleh karenanya, motto ASEAN tersebut membuat Keberadaan AATHP sebagai dasar hukum yang digunakan oleh semua anggota ASEAN untuk membuat produk hukum dalam pencegahan dan penanggulangan kebakaran hutan di negaranya, agar memperkuat secara bersama-sama dalam kedaulatan negara masing-masing untuk menindak kasus kebakaran hutan dan lahan secara tegas. Selain hal tersebut, AATHP juga memperkokoh hubungan kerjasama regional dan internasional dalam hal percepatan penanganan kebakaran hutan dan lahan.

Terdapat 32 Pasal secara keseluruhan dalam AATHP. Adapun 32 Pasal ini terdiri dari:

a. Ketentuan Umum

Pasal 1-4 dalam Bab I Ketentuan Umum ini pada dasarnya berisi tentang definisi dari istilah-istilah yang digunakan, tujuan, prinsip, dan kewajiban umum yang ada dalam AATHP.

b. Pemantauan, Penilaian, Pencegahan, dan Tanggapan.

Pasal 5-15 dalam Bab II mengatur bahwa tiap anggota ASEAN harus benar siap dalam melaksanakan aktivitas pemantauan, penilaian, pencegahan, dan tanggapan saat terjadi kebakaran hutan dan lahan di negaranya yang berpotensi dapat menyebabkan pencemaran udara lintas batas Negara.

c. Kerja Sama Teknis dan Penelitian Ilmiah

Pasal 16 dan 17 dalam Bab III mengatur tentang kerja sama teknis dan penelitian ilmiah antara Anggota dan ASEAN Centre yang mana ASEAN Centre harus memfasilitasi aktifitas kerja sama teknis guna melaksanakan proses pencegahan dan penaggulangan pencemaran udara lintas batas Negara akibat dari kebakaran hutan dan lahan.

d. Pengaturan Kelembagaan

Pasal 18 - Pasal 20 bab IV berisikan tentang pengaturan kelembagaan

e. Prosedur 
Pasal 21 - Pasal 27 mengatur tentang prosedur dan keuangan untuk pengendalian pencemaran udara lintas batas negara akibat kebakaran hutan dan lahan harus melalui hasil mufakat.

f. Ketentuan Akhir

Pasal 28-31 merupakan Bab ketentuan akhir dalam Perjanjian internasional ini.

\section{Implementasi ASEAN Agreement Transboundary Haze Pollution di Indonesia.}

Indonesia telah meratifikasi AATHP melalui Undang-Undang Nomor 26 Tahun 2014, guna mengatasi pencemaran asap lintas batas secara efekif yang diakibatkan oleh Kebakaran Hutan dan Lahan. Hal ini demi tercapainya tujuan Masyarakat Sosial Budaya ASEAN.

Perjanjian ini berisi mengenai ketentuan dalam pengawasan, penilaian dan pencegahan, kerjasama teknis, dan penelitian ilmiah, mekanisme dalam koordinasi, jalur komunikasi dan penyederhanaan prosedur imigrasi bagi penanggulangan bencana. Berdasarkan perjanjian ini, maka didirikan ASEAN Coordinating Center for Transboundary Haze Pollution Control yang bertujuan untuk menangani berbagai aktivitas yang harus dilaksanakan menurut perjanjian (Hakim, 2007)

Indonesia, sebagai bentuk komitmen dalam mematuhi isi dari Pasal 9 AATHP, membentuk produk hukum nasional dalam rangka penindakan hukum terhadap tindakan pidana pelaku pembakaran hutan dan lahan. Hal ini dibuktikan dengan disahkannya UU Perlindungan dan Pengelolaan Lingkungan Hidup (UUPPLH), UU Kehutanan, UU Perkebunan, dan UU Pencegahan dan Pemberantasan Perusakan Hutan. UUPPLH yang dalam isinya terdapat pengaturan larangan pembukaan lahan dengan cara pembakaran hutan, maka diberikan sanksi berupa pidana penjara dan denda.

Di sisi yang berbeda, pengaturan tentang sanksi terhadap orang yang membakar hutan diatur dengan Undang-Undang Kehutanan. Selain itu, UU Perkebunanan mengatur bahwa setiap para pemilik Pelaku Usaha Perkebunan, terdapat larangan untuk membuka dan/atau mengolah lahan dengan cara membakar. Jika tindakan ini dilakukan, maka akan ada sanksi pidana penjara dan denda.

Selanjutnya, Peraturan Menteri dan Presiden terkait isu kebakaran hutan dan/atau lahan yang berpedoman pada aturan AATHP adalah Peraturan Menteri Lingkungan Hidup dan Kehutanan RI No: P.74/menlhk/setjen/kum.1/8/2016 tentang Pedoman Nomenklatur Perangkat Daerah Provinsi dan Kabupaten/Kota Urusan Pemerintah Bidang Lingkungan Hidup dan Kehutanan. Peraturan ini merupakan bentuk tindak lanjut dari amanah Pasal 211 ayat (2) Undang-Undang Nomor 23 Tahun 2014 tentang Pemerintah Daerah dan pasal 109 ayat (1) PP Nomor 18 Tahun 2016 tentang perangkat daerah.

Berdasarkan Peraturan Menteri Lingkungan Hidup dan Kehutanan ini, pemerintah daerah akan menetapkan stuktur organisasi, tata hubungan kerja, tugas dan fungsi dari Dinas Lingkungan Hidup dan Kehutanan yang ditetapkan melalui Peraturan Gubernur dan Peraturan Walikota. Jadi setiap daerah diamanatkan tugas untuk membuat sistem regulasi pemanfaatan hutan, yang mana hal ini sesuai dengan yang diinginkan oleh AATHP agar negara anggota membuat regulasi tentang pemanfaatan hutan yang melibatkan berbagai pihak yang dianggap perlu, salah satunya pemerintahan daerah.

Provinsi Jambi yang merupakan kesatuan dari Negara Indonesia, wajib turut serta mewujudkan tujuan dari masyarakat Sosial Budaya ASEAN, karena merupakan bagian dari masyarakat ASEAN itu sendiri. Salah satu caranya dengan mencegah terjadi kebakaran hutan dan lahan di Provinsi Jambi, yang dampaknya tidak hanya dirasakan oleh masyarakat di Provinsi Jambi, namun dapat dirasakan seluruh Masyarakat ASEAN, terutama dampak dari pencemaran udara lintas batas negara akibat kebakaran hutan dan lahan yang terjadi. Oleh karenanya, dibentuklah Peraturan Daerah Provinsi (PERDA) Jambi Nomor 2 Tahun 2016 tentang Pencegahan Dan Pengendalian Kebakaran Hutan Dan Lahan. 
PERDA Provinsi Jambi ini pada dasarnya mengatur larangan bagi setiap orang/badan hukum untuk membakar hutan dan lahan guna membuka hutan/lahan tersebut. Selain itu, terdapat pula pengaturan sanksi hukum administrasi terhadap pemegang izin jika dalam pengawasan ditemukan pelanggaran terkait pencegahan dan pengendalian kebakaran hutan dan lahan. Setiap orang atau pemegang izin yang dengan sengaja dan/atau karena kelalaiannya menyebabkan terjadinya pencemaran dan kerusakan lingkungan akibat kebakaran hutan dan lahan diancam dengan pidana sesuai peraturan perundang-undangan.

Keberlakuan PERDA Provinsi Jambi Nomor 2 Tahun 2016 tentang Pencegahan Dan Pengendalian Kebakaran Hutan Dan Lahan menunjukan bahwa Indonesia telah memiliki produk hukum terkait pencegahan kebakaran hutan dan lahan di tingkat nasional dan juga di tingkat lokal, dan hal tersebut membuktikan bahwa adanya keinginan kuat Indonesia untuk berkomitmen dan tunduk terhadap AATHP, Meskipun Indonesia belum memiliki aturan khusus yang mengatur tentang pencemaran kabut asap lintas batas negara.

Persoalan yang muncul dalam rangka menanggulangi pencemaran asap lintas batas, AATHP mengembangkan kebijakan pembukaan lahan tanpa bakar (zero burning policy) yang diatur dalam Pasal 9 ayat (1). Sayangnya, ketentuan ini bertentangan dengan beberapa peraturan perundang-undangan yang ada di Indonesia. Padahal seharusnya ada harmonisasi ketentuan dalam perundang-undangan dengan ketentuan dalam AATHP. Adapun Peraturan perundang-undangan yang bertentangan tersebut terdapat Pada Pasal 69 ayat 2 UUPPLH: "Ketentuan sebagaimana dimaksud pada ayat (1) huruf h memperhatikan dengan sungguhsungguh kearifan lokal di daerah masing-masing."

Penjelasan umum UUPPLH ini menyatakan kearifan lokal yang dimaksud adalah melakukan pembakaran lahan dengan luas lahan maksimal 2 hektar per kepala keluarga untuk ditanami tanaman jenis varietas lokal dan dikelilingi oleh sekat bakar sebagai pencegah penjalaran api ke wilayah sekelilingnya. Hal ini didukung pula dengan adanya Peraturan Menteri Negara Lingkungan Hidup Nomor 10 Tahun 2010 tentang Mekanisme Pencegahan Pencemaran dan/atau Kerusakan Lingkungan Hidup yang Berkaitan dengan Kebakaran Hutan dan/ atau Lahan, menurut Permen ini, masyarakat hukum adat diperbolehkan untuk melakukan pembakaran lahan dengan luas lahan maksimum 2 (dua) hektar per kepala keluarga untuk ditanami jenis varietas lokal.

\section{SIMPULAN}

Salah satu langkah yang ditempuh guna pencegahan terjadinya kebakaran dan lahan di Indonesia yaitu dengan Indonesia meratifikasi AATHP. AATHP merupakan perjanjian yang dibentuk oleh negara Anggota ASEAN, hal ini dikarenakan ASEAN memiliki motto One Vision, One Identity, One Community. Oleh karenanya, motto ASEAN tersebut membuat Keberadaan AATHP sebagai dasar hukum yang digunakan oleh semua anggota ASEAN untuk membuat produk hukum dalam pencegahan dan penanggulangan kebakaran hutan di negaranya, agar memperkuat secara bersama-sama dalam kedaulatan negara masing-masing untuk menindak kasus kebakaran hutan dan lahan secara tegas. adapun salah satu langkah yang dilakukan Indonesia dalam implementasi AATHP adalah dengan membuat peraturan perundangan-undangan yang berkaitan dalam pencegahan terjadinya kebakaran hutan dan lahan. Hal ini ditandai dengan disahkannya UU Perlindungan dan Pengelolaan Lingkungan Hidup, UU Kehutanan, UU Perkebunan, dan UU Pencegahan dan Pemberantasan Perusakan Hutan. Selain itu, di Provinsi Jambi, juga membentuk Peraturan Daerah Provinsi Jambi Nomor 2 Tahun 2016 tentang Pencegahan Dan Pengendalian Kebakaran Hutan Dan Lahan. 


\section{DAFTAR PUSTAKA}

ASEAN Haze Action. (2015, September 17). Status of Ratification. ASEAN Haze Action Online. http://haze.asean.org/status-of-ratification/ (August 20, 2020).

Asmardika, R. (2019). "Kabut Asap Dari Indonesia Capai Thailand, Selimuti Resor Wisata Di Phuket." okezone.com. https://news.okezone.com/read/2019/09/23/18/2108192/kabut-asap-dari-indonesiacapai-thailand-selimuti-resor-wisata-di-phuket (August 17, 2020).

Barr, Christopher M. \& Center for International Forestry Research. \& World Wide Fund for Nature. Macroeconomics for sustainable Development Program Office. (2001). Banking on sustainability : structural adjustment and forestry reform in post-Suharto Indonesia /by Christopher Barr. Washington, D.C : WWF Macroeconomics Program Office

Direktorat Jenderal Kerjasama ASEAN. (2018). ASEAN Selayang Pandang, 23rd ed. Jakarta: Direktorat Jenderal Kerjasama ASEAN

Gusliana, H. B. (2019). The Authority of the Local Government in Forest Management and its Implication toward Local Autonomy in Riau Province. Jambe Law Journal, 1(2), 251-267. https://doi.org/10.22437/jlj.1.2.251-267

Hakim, Fika Yulialdina. 2007. "International Law Making ASEAN Agreement on Transboundary Haze Pollution." Indonesia Journal of International Law 4(4): 816-30.

Kamil, M. (1999). Prinsip-Prinsip dalam Hukum Lingkungan Internasional. Jurnal Hukum \& Pembangunan, 29(2), 107. https://doi.org/10.21143/jhp.vol29.no2.553

Koplitz, S. N., Mickley, L. J., Marlier, M. E., Buonocore, J. J., Kim, P. S., Liu, T., Sulprizio, M. P., DeFries, R. S., Jacob, D. J., Schwartz, J., Pongsiri, M., \& Myers, S. S. (2016). Public health impacts of the severe haze in Equatorial Asia in September-October 2015: demonstration of a new framework for informing fire management strategies to reduce downwind smoke exposure. Environmental Research Letters, 11(9), 094023. https://doi.org/10.1088/1748-9326/11/9/094023

McMillan, D. W., \& Chavis, D. M.. (1986). "Sense of Community: A Definition and Theory." Journal of Community Psychology 14(1): 6-23.

Perdana, A. V. (2019). "Kabut Asap Selimuti Langit Di Thailand Selatan, Disebut Akibat Karhutla Di Indonesia." Kompas.com. https://internasional.kompas.com/read/2019/09/23/19282121/kabut-asap-selimuti-langitdi-thailand-selatan-disebut-akibat-karhutla?page=all (August 17, 2020).

Potter, L., Padoch, C., \& Peluso, N. L. (January 01, 1996). Forest degradation, deforestation, and reforestation in Kalimantan: Towards a sustainable land use?. Borneo in Transition : People, Forests, Conservation, and Development, 13-40.

Puspita, N. Y. (2015). KEWENANGAN HUKUM ASEAN DALAM MEMBUAT PERJANJIAN INTERNASIONAL DENGAN PIHAK EKSTERNAL BERDASARKAN PIAGAM ASEAN. Yustisia Jurnal Hukum,4(3), 719-745. 
https://doi.org/10.20961/yustisia.v4i3.8704

Putri, W. D. (2015, December 20). BNPB Catat Kerugian Akibat Kebakaran Hutan 2015 Rp $221 \quad$ Triliun. Republika Online. https://nasional.republika.co.id/berita/nasional/umum/15/12/20/nzms82359-bnpb-catatkerugian-akibat-kebakaran-hutan-2015-rp-221-triliun (February 17, 2020).

Schweithelm, J., \& Barber, C. V. (2000). Trial by Fire : Forest Fires and Forestry Policy in Indonesia's Era of Crisis and Reform. Washington: World Resources Inst.

Sinamo, N. (2009). Metode Penelitian Hukum. Jakarta: PT. Bumi Intitama Sejahtera

Sommers, W. T., Loehman, R. A., \& Hardy, C. C. (2014). Wildland fire emissions, carbon, and climate: Science overview and knowledge needs. Forest Ecology and Management, 317, 1-8. https://doi.org/10.1016/j.foreco.2013.12.014

Suprapto, Y., \& Suryadi. 2020. "Mengulas Karhutla Jambi 2019, Awal Tahun Riau Mulai Kebakaran.” Mongabay. https://www.mongabay.co.id/2020/01/27/mengulas-karhutlajambi-2019-awal-tahun-riau-mulai-kebakaran/ (February 17, 2020).

Tacconi, L. (2003). Kebakaran hutan di Indonesia: penyebab, biaya dan implikasi kebijakan. Kebakaran Hutan Di Indonesia: Penyebab, Biaya Dan Implikasi Kebijakan, 1-28. https://doi.org/10.17528/cifor/001200

Tempo. (2016). "Riset: Ada 100.300 Kematian Akibat Kebakaran Hutan 2015." tempo.co. https://nasional.tempo.co/read/805612/riset-ada-100-300-kematian-akibat-kebakaranhutan-2015?page_num=1 (February 17, 2020).

The Thaiger. (2019, April 13). Forest fires destroy 2.7 million rai of land whilst Chiang Mai is back on top. https://thethaiger.com/hot-news/air-pollution/forest-fires-destroy-2-7million-rai-of-land-whilst-chiang-mai-is-back-on-top (February 17, 2019).

Triadmodjo, M. (2000). "Anatomi Hukum Lingkungan International: Sistem Generik Penyangga Kehidupan Ummat Manusia." Jurnal i-lib UGM 2: 128-42. http://ilib.ugm.ac.id/jurnal/download.php?dataId=2415.

UNISDR. 2002. "Disaster Reduction and Sustainable Development Disaster Reduction and Sustainable Development Understanding the Links between Vulnerability and Risk to Disasters Related to Development and Environment.” In , 3. www.unisdr.org.

Virgy, M. A., Djuyandi, Y., \& Darmawan, W. B. (2020). Strategi Jaringan Advokasi Transnasional Greenpeace Indonesia Terkait Isu Deforestasi Hutan Indonesia oleh Wilmar International. Journal of Political Issues, 1(2), 74-91. https://doi.org/10.33019/jpi.v1i2.9

Yudha, W., Chandra, M., Petranto, A., J.S. Lantu, G., and Siahaan, B. Y. P. (2017). Satu Visi Satu Identitas Satu Masyarakat. 22nd ed. Jakarta: Sekretariat Direktorat Jenderal Kerja Sama ASEAN, Ditjen Kerja Sama ASEAN, Kementerian Luar Negeri. 


\title{
Politik Hukum Kewenangan Pemerintah Daerah Dalam Pengaturan Hak Kekayaan Intelektual
}

\author{
Darwance $^{1 *}$, Yokotani $^{1}$, Wenni Anggita ${ }^{2}$ \\ ${ }^{1}$ Jurusan Hukum, Fakultas Hukum, Universitas Bangka Belitung, 33172, Bangka-Indonesia \\ ${ }^{2}$ Jurusan Akuntansi, Fakultas Ekonomi, Universitas Bangka Belitung, 33172, Bangka-Indonesia
}

\begin{tabular}{l}
\hline Info Artikel \\
\hline Dikirim: Nov 03, 2020 \\
Diterima: Jan 28, 2021 \\
Dipublikasi: Jan 31, 2021 \\
\hline Kata Kunci: \\
Hak Kekayaan Intelektual; \\
Peraturan; \\
Politik Hukum; \\
\hline
\end{tabular}

Koresponden:

Darwance

Jurusan Hukum

Universitas Bangka Belitung

\section{Email:}

darwance@yahoo.co.id

\section{Sitasi Cantuman:}

Darwance, Yokotani \& Anggita, W. (2021). Politik Hukum Kewenangan Pemerintah Daerah Dalam Pengaturan Hak Kekayaan Intelektual. Journal of Political Issues. 2(2); 124134. https://doi.org/10.33019/jpi.v $2 \mathrm{i} 2.40$

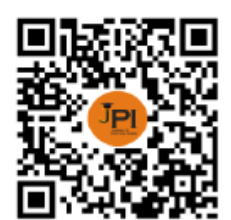

DOI:

https://doi.org/10.33019/jpi.v $2 \mathrm{i} 2.40$

Lisensi:

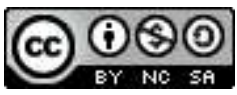

Attribution-NonCommercialShareAlike 4.0 International (CC- BY-NC-SA 4.0)

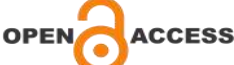

\begin{abstract}
ABSTRAK
Abstract The objects of protection for intellectual property rights are vary greatly. Along with the development of science and technology, the objects of protection for intellectual property rifghts are developing from time to time. The objects are not only in one place. In Indonesia, the protected potential objects spread in various region. In some IPR branches, one of the reasons in because the communal ownership or the discover is no longer known, the IPR perspective cannot be protected, for example traditional knowledge or medicines. Some ofe the case include piracy of biodiversity from knowledge of traditional Indonesian medicines, namely the patenting of the brotowali plant by Japanes company. On the other hand, the statutory regulations on IPRs have minimal direct authority to local governments regarding IPR protection. Therefore, this normative research with laws and regulations approach exemines legal politics of local government authority in laws and regulations in the field of intellectual property rights. The result is from all of laws and regulations in the field of IPR, explicitly the authority of local government is only regulated in Law Number 20 Year 2016 Concerning on Mark and Geographical Indications. The rest is general in nature, for example the use of the term "state" in the Copyrights Law as the holder of traditional cultural expressions and copyright of works whose creatoris unknown. In fact, in the context of a rule of law, government authority derives from the prevailing laws and regulations, in line with the legality principle which is the basis in every state and government administration.
\end{abstract}

Abstrak Seiring dengan perkembangan ilmu pengetahan dan teknologi, objek perlindungan hak kekayaan intelektual pun semakin berkembang dari waktu ke waktu. Objek-objek yang dimaksud tidak hanya ada di satu tempat saja, tetapi menyebar di berbagai daerah. Pada beberapa cabang HKI, salah satunya karena kepemilikan komunal atau penemunya tidak lagi diketahui, tidak dapat diberikan perlindungan perspektif HKI, misalnya pengetahuan atau obat-obatan tradisional. Beberapa kasus di antaranya adalah pembajakan keanekaragaman hayati dari pengetahun obat-obatan tradisional Indonesia, yakni dipatenkannya tanaman brotowali oleh perusahaan Jepang. Di sisi lain, peraturan perundang-undangan bidang HKI minim memberikan kewenangan secara langsung kepada pemerintah daerah berkaitan dengan perlindungan HKI. Oleh sebab itu, penelitian yang bersifat normatif dengan pendektan peraturan perundang-undangan ini mengkaji politik hukum tentang kewenangan pemerintah daerah dalam peraturan perundangundangan di bidang hak kekayaan intelektual. Hasilnya, dari seluruh peraturan perundangundangan bidan HKI, kewenangan pemerintah daerah secara eksplisit hanya diatur dalam Undang-Undang Merek dan Indikasi Geografis. Selebihnya penyebutannya bersifat umum, misalnya penggunaan istilah "negara" dalam Undang-Undang Hak Cipta sebagai pemegang ekspresi budaya tradisional dan hak cipta atas ciptaan yang penciptanya tidak diketahui. Padahal, dalam konteks negara hukum, wewenang pemerintahan berasal dari peraturan perundang-undangan yang berlaku, sejalan dengan asas legalitas yang merupakan dasar dalam setiap penyelenggaraa kenegaraan dan pemerintahan.

\footnotetext{
Tentang:

Darwance, menyelesaikan studi (S2) di Fakultas Hukum Universitas Gadjah Mada Yogyakarta pada tahun 2014. Saat ini penulis adalah dosen tetap di Fakultas Hukum Universitas Bangka Belitung.

Yokotani, menyelesaikan studi (S2) di Sekolah Tinggi Ilmu Hukum (STIH) Pertiba pada tahun 2011. Saat ini penulis adalah dosen tetap di Fakultas Hukum Universitas Bangka Belitung.

Wenni Anggita, menyelesaikan studi (S2) Jurusan Akuntansi di Fakultas Ekonomika dan Bisnis Universitas Diponegoro Semarang pada tahun 2014. Saat ini penulis adalah dosen tetap di Jurusan Akuntansi Fakultas Ekonomi Universitas Bangka Belitung.
} 


\section{PENDAHULUAN}

Pada dasarnya, manusia dilahirkan dalam kondisi memiliki kemampuan yang berbeda-beda. Dapat pula dikatakan bahwa antara manusia yang satu dengan manusia yang lain, sekalipun umpamanya memiliki potensi yang sama dalam konteks kreativitas, akan tetapi memiliki tingkat keahlian yang berbeda sehingga luaran yang dihasilkan menjadi berbeda pula. Contoh sederhana, tidak semua orang pandai menciptakan lagu. Sekalipun beberapa orang yang memiliki kemampuan yang sama, yakni sama-sama bisa menciptakan lagu, tingkat kepiawaian mereka dalam menciptakan lagu menempati level yang berbeda. Salah seorang di antara mereka bukan hanya bisa menciptakan lagu, tapi lagu-lagu yang ia ciptakan selalu enak dan nyaman di telinga. Sementara salah seorang lagi, bisa menciptakan lagu tapi lagu ciptaanya dianggap biasa-biasa saja.

Dengan beberapa dasar pemikiran, salah satunya bahwa setiap orang memiliki kemampuan yang berbeda dalam mengelola intelektualitasnya, maka lahirlah kemudian konsep perlindungan terhadapnya yang dikenal dengan Hak Kekayaan Intelektual (HKI). HKI salah satunya dimaknai sebagai istilah hukum umum untuk paten, hak cipta, dan merek dagang, yang memberikan hukum hak untuk melindungi ide, ekspresi ide, dan penemu atau pencipta gagasan semacam itu (Rout, 2018). Pada perkembangannya kemudian, cakupan atau objek perlindungan HKI terus berkembang yang semula hanya hak cipta, paten, dan merek, bertambah di antaranya adalah rahasia dagang, desain industri, desain tata letak sirkuit terpadu, perlindungan varietas tanaman, dan indikasi geografis.

Dari aspek historis, secara global dikatakan bahwa HKI bermula dari sejumlah invensi yang berhasil diwujudkan oleh beberapa penemu di Eropa (Saidin, 2019). HKI pada praktiknya memang lebih dahulu berkembang di negara maju. Sedangkan di negara-negara berkembang, termasuk Indonesia, HKI baru menjadi perhatian beberapa dekade terakhir, terutama setelah negara berkembang meratifikasi pembentukan World Trade Organiation (WTO) yang salah satu konsekuensinya adalah harus menyesuaikan pengaturan tentang HKI di negara masing-masing sesuai dengan kehendak WTO. Di Indonesia, sekalipun aturan tentang HKI sudah ada sejak sebelum kemerdekaan, tetapi perhatian terhadap HKI baru betul-betul diseriusi sejak awal tahun 1980-an, ditandai dengan beberapa produk hukum yang mengatur tentang cabang dari HKI, seperti hak cipta, paten, merek, dan lain sebagainya.

Penerapan HKI di Indonesia praktiknya berhadapan dengan sejumlah hal yang dapat pula dikatakan sebagai kendala dalam ranah implementasi. Hal ini diakibatkan oleh konsep HKI yang didominasi oleh hak-hak yang bersifat individualistik (hak kepemilikan indivdu), sementara karakter masyarakat Indonesia adalah komunalistik yang lebih mengutamakan kepentingan bersama. Di sisi lain, teknologi dan merek asing yang datang ke Indonesia untuk dipasarkan, adalah bentuk-betuk produk yang di negara asalnya sudah dilindungi oleh HKI. Beberapa di antaranya misalnya minuman merek Coca Cola yang terdaftar sebagai The Coca Cola Company di Amerika Serikat sejak 27 Maret 1944 (Republika, 2013), atau Kentucky Fried Chicken (KFC) merek dagang waralaba dari Yumi Brands Inc yang bermarkas di Amerika Serikat yang didirikan oleh Colonel Harland Sanders (Kontan.co.id, 2020). Di samping itu pula, pada beberapa cabang HKI, beberapa hal yang ada di tengah-tengah masyarakat kita, salah satunya karena kepemilikan komunal atau penemunya tidak lagi diketahui, tidak dapat diberikan perlindungan perspektif HKI, misalnya pengetahuan atau obat-obatan tradisional. Beberapa kasus di antaranya adalah pembajakan keanekaragaman hayati dari pengetahun obat-obatan tradisional Indonesia, yakni dipatenkannya tanaman brotowali oleh perusahaan Jepang (Rosidawati, 2013).

Pengetahuan tradisional yang dimaksud sebagian besar di antaranya berada di tengahtengah masyarakat Indonesia yang sebagian besar ada di daerah. Hal ini selain ruang lingkup perlindungan HKI semakin meluas, objek yang dimaksud pun tidak hanya ada di satu tempat saja. Dalam konteks Indonesia, objek-objek yang berpotensi diberikan perlindungan menyebar di berbagai daerah. Oleh sebab itu, keterlibatan pemerintah daerah, baik 
pemerintah provinsi maupun kabupaten/ kota, dalam hal ini sangat dibutuhkan dalam memaksimalkan perlindungan di bidang HKI. Di samping itu, sesuai dengan ketentuan Pasal 9 Ayat (1) Undang-Undang Nomor 23 Tahun 2014 tentang Pemerintahan Daerah (UU Pemerintah Daerah) disebutkan urusan pemerintahan terdiri atas urusan pemerintahan absolut, urusan pemerintahan konkuren, dan urusan pemerintahan umum. Sementara itu, kewenangan pemerintahan daerah dapat dibedakan menjadi dua, yaitu kewenangan pemerintahan wajib dan pilihan. Adapun kewenangan pemerintah yang bersifat pilihan terkait dengan potensi unggulan dan kekhasan daerah tertentu, dalam konteks ini termasuk kekayaan hayati yang dimiliki dan menjadi ciri khas sebuah daerah.

Hanya saja, dari regulasi yang ada, politik hukum dalam pengaturan hak kekayaan intelektual tidak melibatkan pemerintah daerah di semua cabang HKI. Pemerintah daerah dilibatkan hanya dalam perlindungan indikasi georgafis, yang tertuang dalam UndangUndang Nomor 20 Tahun 2016 tentang Merek dan Indikasi Geografis (UU Merek dan Indikasi Geografis). Penelitian ini bertujuan untuk mengetahui dan menganalisis bagaimana politik hukum kewenangan pemeintah daerah dalam peraturan perundang-undangan bidang HKI di Indonesia. Oleh sebab itu, pertanyaan dalam penelitian ini yang hendak dikaji adalah bagaimana politik hukum kewenangan pemeintah daerah dalam peraturan perundangundangan bidang HKI di Indonesia?

\section{METODE PENELITIAN}

Penelitian ini adalah penelitian hukum normatif atau yang lazim pula disebut sebagai penelitian kepustakaan, yakni penelitian hukum yang dilakukan dengan cara meneliti bahan pustaka atau data sekunder belaka, meliputi penelitian terhadap asas-asas hukum, sistematik hukum, taraf sinkronisasi vertikal dan horizontal, perbandingan hukum dan sejarah hukum (Soekanto \& Mamudji, 2015). Penelitian hukum normatif meneliti hukum dari perspektif internal dengan objek penelitiannya adalah norma hukum (Diantha, 2017). Pendekatan yang digunakan dalam penelitian ini yakni pendekatan perundang-undangan (statute approach), yakni penelitian yang dilakukan dengan menelaah semua undang-undang dan regulasi yang bersangkut paut dengan isu hukum yang sedang ditangani (Marzuki, 2016). Sumber data yang digunakan merupakan sumber data sekunder, yakni data yang diperoleh dari bahan kepustakaan atau literatur yang mempunyai hubungan dengan objek penelian. Teknik pengumpulan data yang digunakan adalah studi literatur, yakni studi yang mengkaji tentang berbagai dokumen-dokumen, baik yang berkaitan dengan peraturan perundang-undangan maupun dokumen-dokumen yangs sudah ada. Teknik nalisis data yang bersifat kualitatif, yakni analisis yang tidak menggunakan angka, melainkan memberikan gambaran-gambaran (deskripsi) dengan kata, atau temuan-temuan, dan karenanya ia lebih mengutamakan mutu/ kualitas dari data, dan bukan kuantitas (Salim \& Nurbani, 2013).

\section{HASIL PENELITIAN}

\section{Kausul Politik Hukum dan Hak Kekayaan Intelektual}

Secara etimologis politik hukum merupakan terjemahan dari istilah hukum Belanda rechtspolitiek, yang merupakan bentukan dari dua kata recht dan politiek. Adapun dalam kamus bahasa Belanda yang ditulis oleh Van der Tas, kata politiek mengandung arti beleid yang dalam bahasa Indonesia berarti kebijakan (policy). Dari penjelasan itu bisa dikatakan bahwa politik hukum secara singkat berarti kebijakan hukum (Syaukani \& Thihari, 2010).

Beberapa ahli mengutarakan definisi dari politik hukum. Menurut Padmo Wahjono politik hukum adalah kebijakan penyelenggara negara yang bersifat mendasar dalam menentukan arah, bentuk maupun isi dari hukum yang akan dibentuk dan tentang apa yang dijadikan kriteria untuk menghukumkan sesuatu, yakni berkaitan dengan hukum yang berlaku 
di masa mendatang (ius constituendum) hukum (Syaukani \& Thihari, 2010). Sementara itu, Teuku Mohammad Radhie mendefinisikan politik hukum sebagai suatu pernyataan kehendak penguasa negara mengenai hukum yang berlaku di wilayahnya dan mengenai arah perkembangan hukum yang dibangun, mencakup ius constituendum atau hukum yang berlaku di wilayah negara pada saat ini dan ius constitunendum atau hukum yang akan atau seharusnya diberlakukan di masa mendatang hukum (Syaukani \& Thihari, 2010; Mahfud, 2011).

Menurut Soedarto, politik hukum adalah kebijakan dari negara melalui badan-badan negara yang berwenang untuk menetapkan peraturan yang dikehendaki, yang diperkirakan akan digunakan untuk mengekspresikan apa yang terkandung dalam masyarakat dan untuk mencapai apa yang dicita-citakan (Syaukani \& Thihari, 2010; Latif \& Ali, 2011). Satjipto Rahardjo mendefinisikan politik hukum sebagau aktivitas memilih dan cara yang hendak dipakai umtuk mencapai suatu tujuan sosial dengan hukum tertentu di dalam masyarakat (Syaukani \& Thihari, 2010; Latif \& Ali, 2011).

Muchtar Kusumatmadja mengatakan politik hukum adalah kebijakan hukum dan perundang-undangan, dalam rangka pembaruan hukum, yang apabila dikaitkan dengan pengertian hukum adalah menyangkut hukum mana yang perlu dibentuk (diperbaharui, diubah arau diganti) dan hukum mana yang harus dipertahankan agar secara bertahap tujuan negara dapat terwujud (Latif \& Ali, 2011). Sementara itu, Solly Lubis mendefinisikan politik hukum sebagai kebijakan politik yang menentukan aturan hukum apa yang seharusnya berlaku mengatur berbagai hal kehidupan masyarakat dan bernegara (Latif \& Ali, 2011). Menurut Abdul Hakim Garuda Nusantara, secara harfiah politik hukum diartikan sebagai kebijakan hukum (legal policy) yang hendak diterapkan secara nasional oleh pemerintah, yang meliputi penerapan hukum positif secara konsisten, pembangunan hukum dan pembaruan hukum postif yang dianggap telah ketinggalan zaman atau menciptakan hukum baru sesuai dengan perkembangan yang terjadi dalam masyarakat, penegasan fungsi dan kewenangan lembaga penegak hukum dan peningkatan kesadaran hukum masyarakat (Irawan, 2011).

Moh. Mahfud MD mengatakan bahwa politik hukum adalah legal policy atau garis (kebijakan) resmi tentang hukum yang akan diberlakukan baik dengan pembutan hukum baru maupun dengan penggantian hukum lama, dalam rangka mencapai tujuan negara. Politik hukum dengan demikian merupakan pilihan tentang hukum yang akan diberlakukan sekaligus pilihan tentang hukum-hukum yang akan dicabut atau tidak diberlakukan yang kesemuanya dimaksudkan untuk mencapai tujuan negara seperti yang tercantum di dalam Pembukaan Undang Dasar Negara Republik Indonesia Tahun 1945 (UUD NRI) 1945 (Mahfud, 2017).

Setelah mempelajari pendapat-pendapat para ahli di atas, politik hukum dapat dirumuskan sebagai upaya yang dilakukan oleh pemerintah untuk mewujudkan tujuan negara yang dicita-citakan dan tertuang dalam suatu kebijakan hukum (legal policy). Berdasarkan pengertian tersebut dapat pula dirumuskan ruang lingkup kajian politik hukum, meliputi; (1) dasar berlakunya hukum positif (aspek filosofis, yuridis, dan sosiologis); (2) kebijakan hukum pemerintah (legal policy) untuk mewujudkan tujuan hukum dala kehidupan berbangsa dan bernegara; (3) studi terhadap hukum positif yang sudah ada untuk kemudian melakukan amandemen atau perubahan jika ditemukan ketidaksesuaian dengan perkembangan masyarakat; (4) menciptakan hukum baru yang sesuai dengan kebutuhan dan perkembangan masyarakat serta pergaulan internasional; dan (5) penegasan mengenai kewenangan lembagalembaga negara yang merumus tujuan hukum nasional, pembuatan hukum dan melaksanakan hukum secara nyata. Politik hukum HKI adalah kebijakan hukum yang dilakukan oleh pemerintah untuk mewujudkan tujuan peraturan perundang-undangan HKI, kajian mengenai kesesuaiannya dengan kebutuhan masyarakat Indonesia (kepentingan nasional) serta kesesuaianya dengan Pancasila dan UUD NRI 1945, dan melakukan amandemen atau 
menciptakan peraturan perundang-undangan baru yang lebih sesuai dengan kepentingan nasional serta serta tidak bertentangan dengan Pancasila dan UUD NRI 1945 (Irawan, 2011).

\section{Hak Kekayaan Intelektual dan Pengaturannya di Indonesia}

Secara sederhana, HKI merupakan hak yang dimiliki oleh seseorang secara individual atau beberapa orang maupun badan hukum secara komunal atas hasil kreativitasnya dalam mengolah akal dan pikiran, yakni mengolah ide dan gagasan, dan mewujudkannya menjadi sesuatu yang betul-betul nyata. Perlindungan yang dimaksud bukan diberikan kepada benda sebagai wujud kreativitas, tetapi ide dan gagasan yang ada di balik terciptanya benda itu. Ide dan gagasan itulah yang tidak dimiliki oleh setiap manusia (Darwance, Yokotani \& Anggita, 2020).

HKI pada dasarnya sulit diberikan definsi tapi dapat dijelaskan dengan contoh-contoh (Lindsey dkk, 2013). Misalnya, HKI melekat pada sebuah karya berbentuk buku, lagu, dan karya sastra seperti cerita pendek atau novel. Menurut Eddy Damian, HKI merupakan kekayaan tidak berwujud (intangible) hasil olah pikir atau kreativitas manusia yang menghasilkan suatu ciptaan atau invensi di bidang seni, sastra, ilmu pengetahuan dan teknologi yang mempunyai manfaat ekonomi (Imaniyati, 2010). Sementara Rachmadi Usman mengartikan HKI sebagai hak atas kepemilikan atas karya-karya yang timbul atau lahir karena adanya kemampuan intelektualitas manusia dalam ilmu pengetahuan dan teknologi (Usman, 2002).

HKI lazimnya dibagi atas dua kelompok, yakni hak milik perindustrian (industrialpropertyrights) dan hak cipta (copyrights). Hak milik perindustrian meliputi paten (patents), merek (trademarks), desain industri (industrialdesign), dan lain-lain. Sedangkan yang termasuk dalam hak cipta dibedakan antara hak cipta (atas seni, sastra, dan ilmu pengetahuan) dan hak-hak yang terkait dengan hak cipta (neigbouringrights). Perbedaan pokok antara hak milik perindustrian dengan hak cipta terletak pada dasar-dasar lahirnya perlindungan. Perlindungan terhadap hak milik perindustrian lahir sejak pengakuan hak tersebut diberikan oleh negara. Dalam hal ini, pendaftaran hak milik industri merupakan suatu keharusan. Sedangkan hak cipta mengenal asas perlindungan otomatis (automaticalprotection) (Hasibuan, 2006).

Pengaturan yang mengaturnya adalah Undang-Undang Nomor 28 Tahun 2014 tentang Hak Cipta, Undang-Undang Nomor 13 Tahun 2016 tentang Paten, Undang-Undang Nomor 30 Tahun 2000 tentang Rahasia Dagang, Undang-Undang Nomor 20 Tahun 2016 tentang Merek dan Indikasi Geografis, Undang-Undang Nomor 31 Tahun 2000 tentang Desain Industri, Undang-Undang Nomor 32 Tahun 2000 tentang Desain Tata Letak Sirkuit Terpadu, dan Undang-Undang Nomor 29 Tahun 2000 tentang Perlindungan Varietas Tanaman.

\section{PEMBAHASAN}

\section{Kewenangan Pemerintah Daerah Dalam Pengaturan HKI}

Penyelenggaraan pemerintahan daerah merupakan bentuk realisasi dari UUD NRI 1945, bertujuan agar pemerintah daerah menjadi bagian dari sistem pemerintahan Indonesia sebagai upaya mengatur hubungan antara pemerintah pusat dan pemerintah daerah. Pada prinsipya, kewenangan pemerintahan daerah dibedakan menjadi dua, yaitu kewenangan pemerintahan wajib dan pilihan. Kewenangan pemerintah yang bersifat pilihan terkait dengan potensi unggulan dan kekhasan daerah tertentu. Pada hakikatnya urusan pemerintah pusat yang diserahkan kepada pemerintah daerah adalah urusan pemerintah daerah dalam menyelenggarakan semua urusan pemerintahan kecuali urusan politik luar negeri, pertahanan, keamanan, yustisi, moneter dan fiskal nasional serta agama (Antikowati \& Indrayati, 2017). Dalam bidang hukum dan hak asasi manusia misalnya, di daerah ada Kantor Wilayah Kementerian Hukum dan Hak Asasi Manusia yang menjadi wakil pemerintah pusat dalam urusan hukum dan hak asasi manusia. 
Selain itu, otonomi daerah dalam sistem negara kesatuan seperti Indonesia ditekankan pada adanya kemandirian daerah untuk mengurus dan mejalankan sebagian urusan yang menjadi wewenangnya. Otonomi daerah dengan demikian bukan berarti kemerdekaan dalam setiap pengambilan kebijakan, tetapi kewenangan yang harus berdasarkan peraturan perundang-undangan yang berlaku (Hakim, 2012). Di sisi lain, pemberian urusan dengan kewenangan yang luas, nyata dan bertanggung jawab kepada daerah mengandung dua pengertian, yaitu pemberian urusan diberikan sepenuhnya, namun tidak semua urusan diberikan kepada pemerintah daerah melainkan sebagian urusan Negara Kesatuan Republik Indonesia. Pembagian urusan otonomi daerah tersebut secara proporsional, yang mengandung pengertian, bahwa pembagian urusan yang dimaksud memperhatikan proporsi atau bagian yang berimbang masing-masing pihak, dalam hal ini pihak pemerintah pusat dan pihak pemerintah daerah (Huda, 2012).

Sebagai bentuk perpanjangan tangan dari pusat dan sebagai unsur penyelenggara pemerintahan daerah, pemerintah daerah mempunyai peranan untuk memimpin pelaksanaan urusan pemerintahan yang menjadi kewenangan daerah otonom. UU Pemerintah Daerah secara jelas memberikan kewenangan penuh bagi daerah untuk mengelola potensi daerah apa saja yang mengandung nilai ekonomis (Purwaka, 2017). Dalam konteks otonomi daerah, pemerintah daerah memiliki kewenangan dalam mengurus pemerintahannya sendiri dengan memperhatikan prinsip demokrasi, pemerataan, keadilan yang pada dasarnya diarahkan untuk mempercepat terwujudnya kesejahteraan masyarakat melalui peningkatan, pelayanan, pemberdayaan, dan peran serta masyarakat yang ada di daerah. Selain itu, dengan kewenangan yang dimiliki tersebut akan meningkatan daya saing daerah.

Berkaitan dengan HKI, ternyata tidak semua undang-undang tentang HKI yang memberikan kewenangan kepada pemerintah daerah. Dalam Undang-Undang Nomor 28 Tahun 2014 tentang Hak Cipta (UUHC) politik hukum mengendaki tidak ada peran pemerintah daerah dalam perlindungan hak cipta. Hal yang sama juga terjadi pada UndangUndang Nomor 13 Tahun 2016 tentang Paten (UU Paten). Pembentuk undang-undang juga menyepakati tidak adanya peran pemerintah daerah dalam perlindungan paten. Sementara itu, dalam Undang-Undang Nomor 20 Tahun 2016 tentang Merek dan Indikasi Geografis (UU Merek dan Indikasi Geografis), politik hukum menghendaki adanya keterlibatan pemerintah daerah. Hal ini dapat dijumpai pada beberapa ketentuan, yakni pasal-pasal yang khusus mengatur tentang indikasi geografis. Sesuai dengan ketentuan Pasal 1 Angka 6 UU Merek dan Indikasi Geografis, indikasi geografis pada prinsipnya merupakan tanda yang mengindikasikan daerah asal suatu barang, daerah asal suatu produk dikarenakan faktor lingkungan geografis. Faktor lingkungan geografis yang dimaksud termasuk termasuk di dalamnya adalah faktor alam, manusia atau kombinasi keduanya. Dari faktor-faktor inilah kemudian lahir reputasi, kualitas, dan karakteristik tertentu pada barang dan/atau produk yang dihasilkan itu.

Lalu, seuai dengan ketentuan Pasal 53 UU Merek dan Indikasi Geografis dikatakan indikasi geografis dilindungi setelah didaftar oleh menteri, dalam konteks ini yakni menteri hukum dan Hak Asasi Manusia (HAM). Ini berarti bahwa indikasi geografis perlindungannya tidak bersifat otomatis, perlu didaftarkan terlebih dahulu sebelum mendapatkan proteksi secara normatif, yakni setelah pemohon mengajukan permohonan kepada menteri. Permohonan dapat diajukan oleh lembaga yang mewakili masyarakat di kawasan geografis tertentu yang mengusahakan suatu barang dan/atau produk berupa sumber daya alam, barang kerajinan tangan atau hasil industri. Selain itu, permohonan bisa juga dilakukan oleh pemerintah daerah, yakni pemerintah provinsi atau pemerintah kabupaten kabupaten/ kota. Pemerintah daerah dengan demikian bisa berposisi sebagai pemohon.

Selain berperan sebagai pemohon, dalam perlindungan indikasi geografis pemerintah daerah juga memiliki peran dalam hal pembinanan dan pengawasan. Hal ini sesuai dengan ketentuan Pasal 70 Ayat (1) UU Merek dan Indikasi Geografis yang secara eksplisit 
menyebutkan bahwa pembinaan indikasi geografis dilakukan oleh pemerintah pusat dan/atau pemerintah daerah sesuai dengan kewenangannya. Pembinaan yang dimaksud, sebagaimana ketentuan Pasal 70 Ayat (2), meliputi persiapan untuk pemenuhan persyaratan permohonan indikasi geografis; permohonan pendaftaran indikasi geografis; pemanfaatan dan komersialisasi indikasi geografis; sosialisasi dan pemahaman atas perindungan indikasi geografis; pemetaan dan inventarisasi potensi produk indikasi geografis; pelatihan dan pendampingan; pemantauan, evaluasi, dan pembinaan; pelindungan hukum; dan fasilitasi pengembangan, pengolahan, dan pemasaran barang dan/atau produk indikasi geografis.

Sedangkan soal pengawasan diatur dalam Pasal 71. pengawasan indikasi geografis dilakukan oleh pemerintah pusat dan pemerintah daerah sesuai dengan kewenangannya. Tidak ada penjelasan lebih lanjut kewenangan seperti apa yang dimaksud pada ketentuan ini, termasuk pada bagian penjelasan. Oleh sebab itu, ada beberapa alternatif untuk memaknai isi ketentuan ini, salah satunya merujuk kepada peraturan perundang-undangan yang khusus mengatur tentang kewenangan pemerintah daerah, atau pembagian urusan antara pemerintah pusat dan pemerintah daerah. Selain itu, pengawasan menurut undang-undang ini juga dapat pula dilakukan oleh masyarakat. Baik pengawasan yang dilakukan oleh pemerintah pusat dan pemerintah daerah maupun oleh masyarakat, semuanya dilakukan untuk menjamin tetap adanya reputasi, kualitas, dan karakteristik yang menjadi dasar diterbitkannya indikasi geografis, serta mencegah penggunaan indikasi geografis secara tidak sah. Hasil pengawasan selanjutnya disampaikan kepada pemegang hak indikasi geografis dan/atau menteri.

Selain di UU Merek dan Indikasi Geografis, peran pemerintah daerah tidak dijumpai dalam UU HKI yang lain. Undang-Undang Nomor 29 Tahun 2000 tentang Perlindungan Varietas Tanaman (PVT), tidak ada peran pemerintah daerah. Undang-Undang Nomor 30 Tahun 2000 tentang Rahasia Dagang tidak ada peran pemerintah daerah. Undang-Undang Nomor 31 Tahun 2000 tentang Desain Industri, tidak ada peran pemerintah daerah. UndangUndang Nomor 32 Tahun 2000 tentang Desain Tata Letak Sirkuit Terpadu, tidak ada peran pemerintah daerah.

Seperti yang sudah disampaikan sebelumnya, politik hukum pada dasarnya merupakan kebijakan hukum atau kebijakan penyelenggara negara dalam menentukan arah, bentuk maupun isi dari hukum yang yang dikehendaki, menyangkut hukum mana yang perlu dibentuk (diperbaharui, diubah arau diganti) dan hukum mana yang harus dipertahankan dalam rangka mencapai tujuan negara. Dalam konteks Indonesia, tujuan negara tercantum pada alinea keempat UUD NRI 1945, meliputi melindungi segenap bangsa dan seluruh tumpah darah Indonesia, memajukan kesejahteraan umum, mencerdaskan kehidupan bangsa, serta ikut melaksanakan ketertiban dunia berdasarkan kemerdekaan, perdamaian abadi dan keadilan sosial. Tujuan memajukan kesejahteraan umum adalah tujuan negara kesejahteraan, yakni mencapai kesejahteraan bagi seluruh rakyat Indonesia, tidak hanya dari segi material/ ekonomi saja tetapi juga dari segi spiritual (Soemarsono, 2007).

Dalam teori ilmu negara, masalah tujuan negara dapat dilihat dari 3 (tiga) sudut pandang, yakni tujuan negara berkaitan dengan tujuan akhir manusia, tujuan kekuasaan, dan tujuan kemakmuran. Dalam kaitannya dengan kewenangan pemerintah daerah dalam peraturan perundang-undangan atau pengaturan yang berkaitan dengan HKI, teori negara hukum dengan tujuan kemakmuran relevan untuk dijadikan sebagai bahan kajian. Teori tujuan kemakmuran, terbagi menjadi teori tujuan kemakmuran negara, kemakmuran individu dan teori tujuan kemakmuran rakyat (Soemarsono, 2007). Hal ini sejalan dengan salah satu hak yang ada dalam sebuah karya intelektual seorang atau beberapa orang manusia selain hak moral, yakni hak ekonomi. Hak ekonomi yang terkandung dalam sebuah karya intelektual seharusnya dapat memberikan kemakmuran kepada pemilik karya itu, termasuk yang sifatnya dimiliki bersama-sama (komunal). Hanya saja, sistem individualistik yang dominan pada sistem kepemilikan HKI menuntut peran dan kewenangan badan hukum publik seperti pemerintah daerah dalam upaya perlindungan agar potensi yang ada tidak diklaim terutama 
oleh pihak asing. Selain sebagai pihak yang bisa ikut menjadi pemohon, pemerintah daerah juga seharusnya diberikan kewenangan untuk mendorong upaya perlindungan di level daerah.

Kekuasan pemerintahan adalah bagian dari sistem kekuasaan negara. Hans Kelsen mengnggap negara sebagai badan hukum (rechtpersoon) memiliki hak dan kewajiban, di samping memiliki kekuataan untuk membentuk hukum (mengatur) (Hakim, 2011). Pemerintahan yang dimaksud di sini dapat ditafsirkan meliputi pemerintah daerah sebagai bagian dari sistem pemerintahan sebuah negara. Di samping itu, sebagaimana yang sudah disampaikan sebelumnya, pemerintah daerah memiliki kewenangan yang bersifat pilihan terkait dengan potensi unggulan dan kekhasan daerah tertentu. Pada prinsipnya, urusan yang diberikan kepada pemerintah daerah oleh pemerintah pusat adalah semua urusan pemerintahan, kecual yang berkaitan dengan politik luar negeri, pertahanan, keamanan, yustisi, moneter, fiskal dan agama (Farid, Antikowati, \& Indrayati, 2017).

Dalam konteks perlindungan HKI, potensi yang dimiliki oleh deaerah sekaligus kekayaan yang berpotensi diberikan perlindungan perspektif HKI pun menjadi urusan pemerintah daerah. Hanya saja, politik hukum pembentuk peraturan perundang-undangan HKI di Indonesia belum memberikan ruang kepada pemerintah daerah untuk lebih leluasa mengurusi persoalan perlindungan HKI. Buktinya, dari 7 peraturan perundang-undangan yang mengatur tentang HKI, hanya satu undang-undang yang menyebutkan secara eksplisit kewenangan kepada pemerintah daerah, yakni UU Merek dan Indikasi Geografis. Selebihnya tidak ada sama sekali. Sekalipun diatur, penyebutannya bersifat umum, misalnya penggunaan istilah "negara" dalam UU Hak Cipta sebagai pemegang ekspresi budaya tradisional dan hak cipta atas ciptaan yang penciptanya tidak diketahui.

Dalam konteks negara hukum, wewenang pemerintahan berasal dari peraturan perundang-undangan yang berlaku. Dengan kata lain, dalam hal ini kewenangan hanya diberikan oleh undang-undang. Menurut Ridwan HR, pembuat undang-undang dapat memberikan wewenang pemerintahan tidak hanya kepada organ pemerintahan, tetapi juga terhadap pegawai atau terhadap badan khusus atau bahkan terhadap badan hukum privat (HSB \& Julianthy, 2018). Hal ini sejalan dengan asas legalitas yang merupakan dasar dalam setiap penyelenggaraa kenegaraan dan pemerintahan, yakni setiap penyelenggaraan kenegaraan dan pemerintahan harus memiliki legitimasi berupa kewenangan yang diberikan oleh undang-undang (Said, 2015).

\section{SIMPULAN}

Sampai saat ini, Indonesia sudah memiliki tatatan regulasi yang mengatur tentang HKI. Selain sebagai impilikasi dari keikutseraan Indonesia di beberapa organisasi dan ratifikasi terhadap ketentuan HKI secara global, regulasi yang tertuang dalam berbagai undang-undang ini dimaksudkan agar kekayaan intelektual yang dimiliki oleh manusia Indonesia dapat dilindungi. Sejumlah regulasi yang ada ini menegaskan peran pemerintah dalam melindungi hak warga negara, sekaligus menjadi sejumlah aset potensial yang dimiliki oleh bangsa ini agar tidak diklaim oleh asing. Pemerintah yang dimaksud adalah pemerintah pusat maupun pemerintah daerah. Pemerintah pusat dalam konteks ini tentu tidak bisa melindungi kekayaan intelektual secara mandiri, butuh dukungan dari berbagai pihak terasuk pemerintah daerah. Hanya saja, dari regulasi yang ada, politik hukum dalam pengaturan HKI tidak melibatkan pemerintah daerah di semua cabang HKI. Pemerintah daerah dilibatkan hanya dalam perlindungan indikasi georgafis, yang tertuang dalam UU Merek dan Indikasi Geografis. Peran yang dimaksud adalah peran pemerintah daerah dalam hal pembinaan dan pengawasan. Selebihnya tidak ada sama sekali. Sekalipun diatur, penyebutannya bersifat umum, misalnya penggunaan istilah "negara" dalam UU Hak Cipta sebagai pemegang ekspresi budaya tradisional dan hak cipta atas ciptaan yang penciptanya tidak diketahui. 


\section{UCAPAN TERIMA KASIH}

Terimakasih disampaikan kepada Kementerian Riset dan Teknologi/ Badan Riset dan Inovasi Nasional Republik Indonesia yang sudah mendanai penelitian ini melalui skim Penelitian Dosen Pemula (PDP) tahun pendanaan 2020 yang tertuang dalam kontak Nomor 035/SP2H/LT/DPRM/2020.

\section{DAFTAR PUSTAKA}

Darwance, Yokotani, \& Anggita, W. (2020). Dasar-Dasar Pemikiran Perlindungan Hak Kekayaan Intelektual. Progresif: Jurnal Hukum Volume 14 Nomor 2, 193-208. https://doi.org/10.33019/progresif.v15i2.1998

Diantha, I. M. (2017). Metodologi Penelitian Hukum Normatif Dalam Justifikasi Teori Hukum. Jakarta: Kencana.

Farid, M., Antikowati, \& Indrayati, R. (2017). Kewenangan Pemerintah Daerah dan Partisipasi Masyarakat dalam Pengelolaan Potensi Daerah. e-Journal Lentera Hukum, 71-84.

Hakim, L. (2011). Kewenangan Organ Negara Dalam Penyelenggaraan Pemerintahan. Jurnal Konstitusi Volume IV Nomor 1 Juni, 103-130. http://publishingwidyagama.ac.id/ejournal-v2/index.php/jk/article/view/302

Hakim, L. (2012). Filosofi Kewenangan Organ dan Kelembagaan Daerah. Malang: Setara Press.

Hasibuan, O. (2006). Perlindungan Hak Ekonomi Pencipta Lagu dan Pemegang Hak Terkait di Indonesia (Ringkasan Desertasi). Yogyakarta: Universitas Gajah Mada.

Huda, N. (2012). Hukum Pemerintah Daerah. Bandung: Nusa Media.

HSB, A. M., \& Julianthy, E. M. (2018). Pelaksanaan Kewenangan Atribusi Pemerintahan Daerah Berdasarkan Undang-Undang Nomor 23 Tahun 2014 tentang Pemerintah Daerah. Jurnal Legislasi Indonesia Volume 15 Nomor 2 Juli, 1-8. https://ejurnal.peraturan.go.id/index.php/jli/article/view/164

Imaniyati, N. S. (2010). Perlindungan HKI Sebagai Upaya Pemenuhan Hak Atas Iptek, Budaya dan Seni. Jurnal Media Hukum Volume 17 Nomor 1 Juni, 162-176. https://journal.umy.ac.id/index.php/jmh/article/view/374

Irawan, C. (2011). Politik Hukum Hak Kekayaan Intelektual Indonesia. Bandung: Mandar Maju. 
Kontan.co.id. (2020, Oktober 8). Suka makan kulit ayam KFC? Ini sejarah KFC di Indonesia. Retrieved from kontan.co.id: https://amp.kontan.co.id/news/suka-makankulit-ayam-kfc-ini-sejarah-kfc-di-indonesia

Latif, A., \& Ali, H. (2011). Politik Hukum. Jakarta: Sinar Grafika.

Lindsey, T., Damian, E., Butt, S., \& Utomo, T. S. (2013). Hak Kekayaan Intelektual Suatu Pengantar. Bandung: Alumni.

Marzuki, P. M. (2016). Penelitian Hukum (Edisi Revisi). Jakarta: Kencana.

Mahfud, M. (2011). Membangun Politik Hukum, Menegakan Konstitusi. Jakarta: Rajawali Press.

Mahfud, M. (2017). Politik Hukum di Indonesia. Jakarta: Rajawali Press.

Purwaka, T. H. (2017). Pelindungan Merek. Jakarta: Yayasan Pustaka Obor Indonesia.

Republika. (2013, Mei 8). Hari Ini di 1886, John Pemberton Memperkenalkan Coca Cola. Retrieved from republika.co.id: https://republika.co.id/berita/mmb3r9/hari-ini-di-1886john-pemberton-memperkenalkan-coca-cola

Rosidawati, W. I. (2013). Konsep Perlindungan Pengetahuan Tradisional Berdasarkan Asas Keadilan Melalui Sui Generis (Undang-Undang Republik Indonesia Nomor 13, 2016) Intellectual Propertu System. Jurnal Hukum Ius Quia Iustum Volume 20 Nomor 2, 163185. https://doi.org/10.20885/iustum.vol20.iss2.art1

Rout, S. K. (2018). A Brief Revoew on Intellectual Property Rights with Special Attention on Patent, Journal of Apllied and Advanced Research. Journal Applied and Advanced Research Volume 3 Nomor 2, 73-77.

Said, A. R. (2015). Pembagian Kewenangan Pemerintah Pusat-Pemerintah Daerah Dalam Otonomi Seluas-Luasnya Menurut UUD 1945. Fiat Justicia Jurnal Ilmu Hukum Volume 9 Nomor 4 Oktober - Desember, 577-602.

Saidin, O. (2019). Aspek Hukum Hak Kekayaan Intelektual (Intellectual Property Righs), RajaGrafindo Persada. Jakarta: Raja Grafindo Persada.

Salim, H.S. \& Nurbani, E. S. (2013). Penerapan Teori Hukum Pada Penelitian Tesis dan Disertasi. Jakarta: Raja Grafindo Persada.

Soekanto, S., \& Mamudji, S. (2015). Penelitian Hukum Normatif Suatu Tinjauan Singkat. Jakarta: Jaja Grafindo Persada. 
Soemarsono, M. (2007). Negara Hukum Indonesia Ditinjau Dari Sudut Teori Tujuan Negara. Jurnal Hukum dan Pembangunan Tahun ke-37 Nomor 2 April - Juni, 300-322.

Syaukani, I., \& Thihari, A. A. (2010). Dasar-dasar Politik Hukum. Jakarta: Rajawali Press.

Undang-Undang Republik Indonesia Nomor 29 Tahun 2000 tentang Varietas Tanaman.

Undang-Undang Republik Indonesia Nomor 30 Tahun 2000 tentang Rahasia Dagang.

Undang-Undang Republik Indonesia Nomor 31 Tahun 2000 tentang Desain Industri.

Undang-Undang Republik Indonesia Nomor 32 Tahun 2000 tentang Desain Tata Letak Sirkuit Terpadu.

Undang-Undang Republik Indonesia Nomor 13 Tahun 2016 tentang Paten.

Undang-Undang Republik Indonesia Nomor 20 Tahun 2016 tentang Merek.

Undang-Undang Republik Indonesia Nomor 23 Tahun 2014 tentang Pemerintahan Daerah.

Undang-Undang Republik Indonesia Nomor 28 Tahun 2016 tentang Hak Cipta.

Usman, R. (2002). Hukum Hak atas Kekayaan Intelektual; Perlindungan dan Dimensi Hukumnya di Indonesia. Bandung: Alumni. 


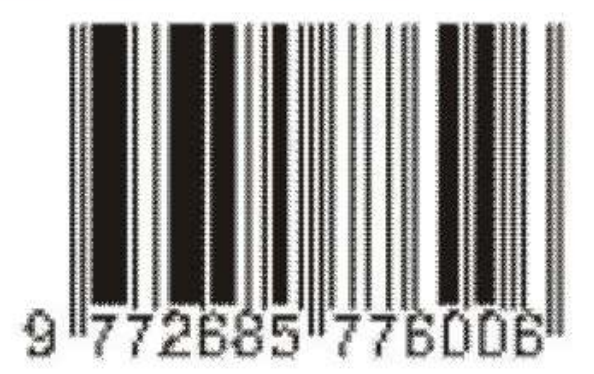

\section{JPI: JOURNAL OF POLITICAL ISSUES}

Universitas Bangka Belitung

Jurusan Ilmu Politik

Desa Balunijuk, Kecamatan Merawang, Kabupaten Bangka, Kepulauan Bangka Belitung, 33172 editor@jpi.ubb.ac.id 